\title{
PADRÕES DEMOGRÁFICOS DE PERFILHAMENTO E PRODUÇÃO DE FORRAGEM EM PASTOS DE CAPIM- MOMBAÇA SUBMETIDOS A REGIMES DE LOTAÇÃO INTERMITENTE
}

\section{MARINA CASTRO UEBELE}

\begin{abstract}
Dissertação apresentada à Escola Superior de Agricultura "Luiz de Queiroz", Universidade de São Paulo, para a obtenção do título de Mestre em Agronomia, Área de Concentração: Ciência Animal e Pastagens.
\end{abstract}

Piracicaba

Estado de São Paulo - Brasil

Abril - 2002 


\title{
PADRÕES DEMOGRÁFICOS DE PERFILHAMENTO E PRODUÇÃO DE FORRAGEM EM PASTOS DE CAPIM- MOMBAÇA SUBMETIDOS A REGIMES DE LOTAÇÃO INTERMITENTE
}

\author{
MARINA CASTRO UEBELE \\ Engenheiro Agrônomo
}

Orientador: Prof. Dr. Sila Carneiro da Silva

\begin{abstract}
Dissertação apresentada à Escola Superior de Agricultura "Luiz de Queiroz", Universidade de São Paulo, para a obtenção do título de Mestre em Agronomia, Área de Concentração: Ciência Animal e Pastagens.
\end{abstract}

Piracicaba

Estado de São Paulo - Brasil

Abril - 2002 
Dados Internacionais de Catalogação na Publicação (CIP) DIVISÃO DE BIBLIOTECA E DOCUMENTAÇÃO - ESALQ/USP

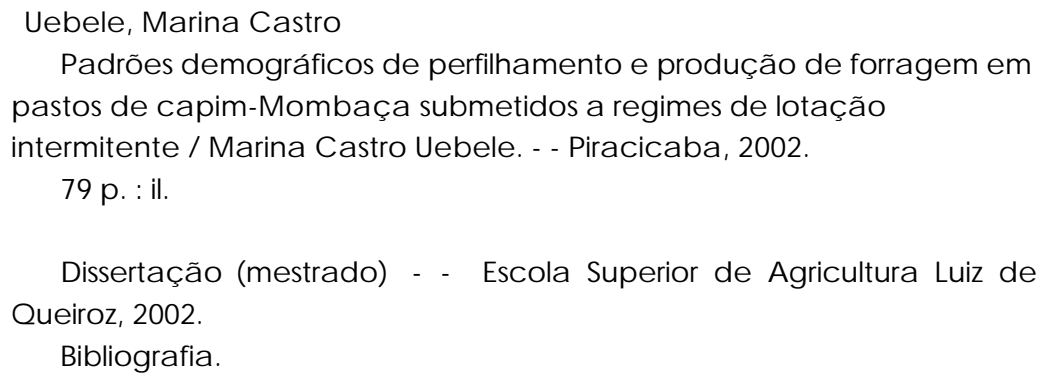

1. Capim colonião 2. Forragem 3. Perfilhação I. Título 
Aos meus pais,

Anna Maria e Thomas

E às minhas irmãs,

Anna Cristina e Anna Carolina

Dedico 
Do dicionário Houaiss, Orientador: profissional que orienta o aluno visando ao desenvolvimento integral e harmonioso de sua personalidade, aconselhando-o nos rumos que deve seguir, segundo suas aptidões, motivações... Durante a minha graduação e também no curso de mestrado tive a sorte de ter como orientador o professor Sila, pessoa que define, assim como o dicionário, o que é ser um orientador. A você Sila, o meu mais especial agradecimento. 


\section{AGRADECIMENTOS}

À ESALQ, através do Departamento de Produção Animal, pela oportunidade de realização do curso de Mestrado.

À Fundação de Amparo à Pesquisa do Estado de São Paulo (FAPESP), pelo suporte financeiro para a execução desse trabalho.

Aos demais professores e a todos os funcionários do Departamento de Produção Animal, especialmente à Creide Ely Martins.

Ao meu colega de graduação e mestrado Adriano Vecchiatti Lupinacci, por estar sempre disposto a ajudar.

Ao Professor Jozivaldo Prudêncio de Moraes e todos os alunos do GETAP, pela concessão da área para a realização do projeto e auxílio no desenvolvimento desse trabalho.

A toda a equipe do capim-Mombaça: Roberta Aparecida Carnevalli, Adriana Amaral de Oliveira, Fernando de Oliveira Bueno e Glaciliana Nunes, companheiros de incansável trabalho.

Ao Professor Wilson Mattos, pelo carinho. 
Às minhas amigas/irmãs Cléa Santos Rahal, Joyce Athayde Veiga, Lia Lima Gatti, Raquel Souza Dias, Renata Camunhas Martins, Renata Boranga Baptista e Roberta W. da Costa Marques, pela presença constante em minha vida e amizade verdadeira.

À querida amiga Laura Santis Prada, companheira de Araras e de tantas viagens, para mim, um exemplo de vida e consciência.

Ao meu querido Walter Miguel Ribeiro, pelo companheirismo, carinho, paciência e ajuda imprescindível.

Às minhas irmãs Anna Cristina e Anna Carolina, por tanto amor.

Aos meus pais, Anna Maria e Thomas, que me apoiaram e incentivaram sempre, obrigada por serem tão maravilhosos. 


\section{SUMÁRIO}

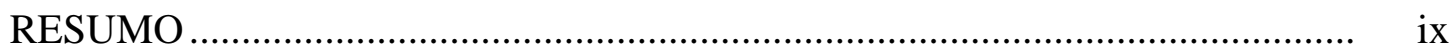

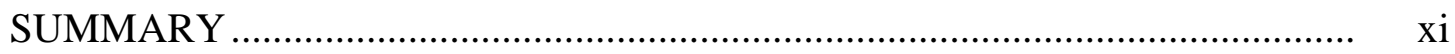

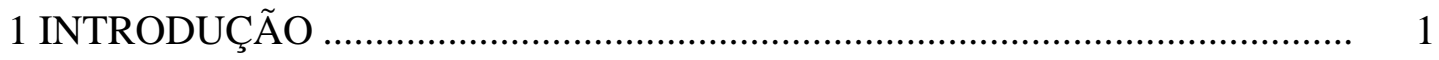

2 REVISÃO DE LITERATURA …........................................................ 3

2.1 Plantas forrageiras em pastagens........................................................... 3

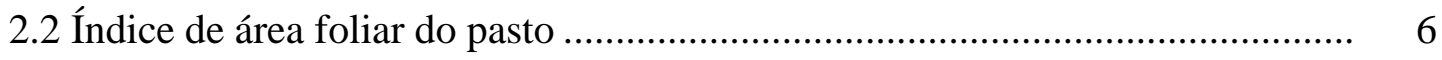

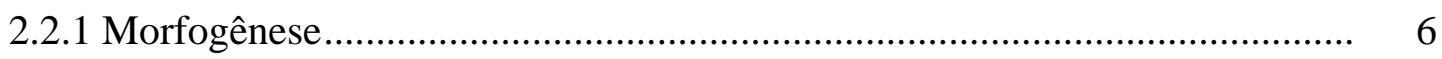

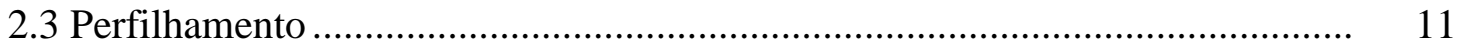

2.3.1 Compensação tamanho/densidade populacional de perfilhos em pastagens.. 12

2.3.2 Variações estacionais em densidade populacional de perfilhos .................... 16

2.3.2.1 Manipulação da estacionalidade da demografia populacional de perfilhos para fins de manejo do pastejo ........................................................ 18

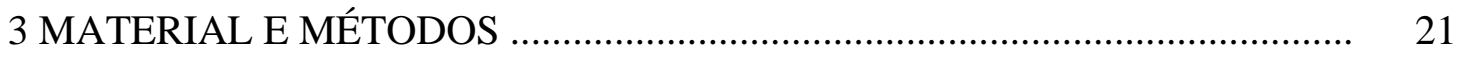

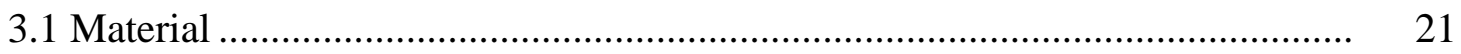

3.1.1 Local e período do experimento........................................................... 21

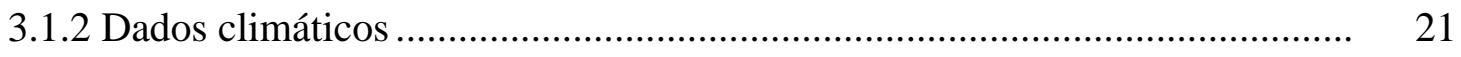

3.1.3 Solo da área experimental ............................................................... 23

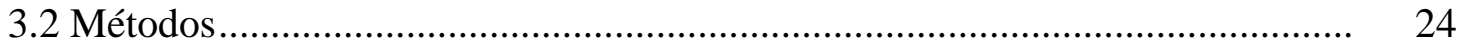

3.2.1 Delineamento experimental e tratamentos .............................................. 24

3.2.2 Monitoramento das condições experimentais e adubação dos pastos............ 26

3.2.3 Padrões demográficos de perfilhamento ................................................ 28 
3.2.4 Densidade populacional de perfilhos ........................................................... 29

3.2.5 Altura do pasto .................................................................................. $\quad 30$

3.2.6 Massa de forragem ........................................................................... $\quad 30$

3.2.7 Taxas de acúmulo de forragem .................................................................. 31

4 RESULTADOS E DISCUSSÃO ……………………............................... 33

4.1 Intervalo médio entre pastejos..................................................................... 33

4.2 Altura média do pasto ……………………………….............................. 36

4.2.1 Pré-pastejo ..................................................................................... 36

4.2.2 Pós-pastejo ............................................................................... 38

4.3 Massa de forragem do pasto ......................................................................... 41

4.3.1 Pré-pastejo ............................................................................................. 41

4.3.2 Pós-pastejo ...................................................................................... 42

4.4 Demografia do perfilhamento .................................................................... 43

4.4.1 Taxas de aparecimento ........................................................................... 48

4.4.2 Taxas de mortalidade da população e das gerações de perfilhos .................... 50

4.4.3 Taxas de sobrevivência ............................................................................... 56

4.4.4 Proporção de perfilhos aéreos ....................................................................... 58

4.5 Densidade populacional de perfilhos …………………………………......... 59

4.5.1 Pré-pastejo …………………………………….............................. 59

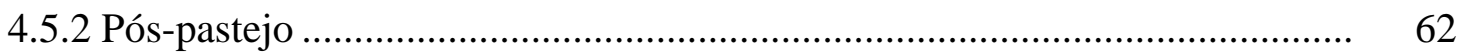

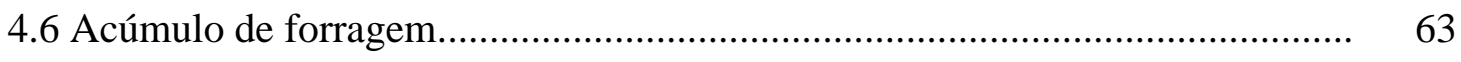

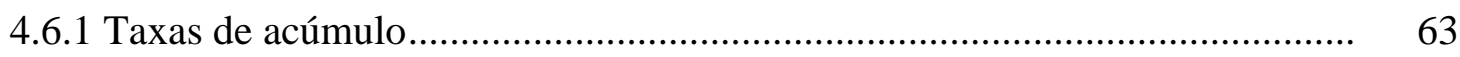

4.6.2 Acúmulo total de forragem ....................................................................... 65

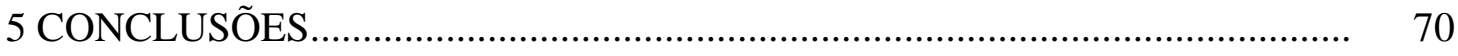

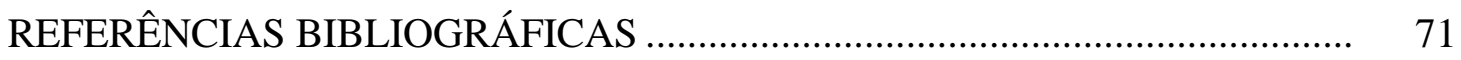




\title{
PADRÕES DEMOGRÁFICOS DE PERFILHAMENTO E PRODUÇÃO DE FORRAGEM EM PASTOS DE CAPIM-MOMBAÇA SUBMETIDOS A REGIMES DE LOTAÇÃO INTERMITENTE
}

\author{
Autora: Marina Castro Uebele \\ Orientador: Prof. Dr. Sila Carneiro da Silva
}

\section{RESUMO}

A otimização de sistemas de pastejo não pode ser concebida simplesmente como a maximização da quantidade de forragem produzida ou ingerida pelos animais, sendo necessário considerar parâmetros que condicionam e determinam a persistência e a produtividade da pastagem. Nesse ponto, assegurar a capacidade de reposição de perfilhos assume importância fundamental. Dentro desse contexto, o objetivo deste experimento foi avaliar os efeitos de diferentes combinações entre intensidade e frequência de desfolha sobre a dinâmica, a densidade populacional de perfilhos e o acúmulo de forragem em pastos de capim-Mombaça pastejados por bovinos, visando determinar estratégias de manejo do pastejo que permitam obter alta produtividade e utilização de forragem, mantendo a estrutura do pasto dentro de limites aceitáveis de uso e garantindo, assim, a sua perenização. O experimento foi realizado na Universidade Federal de São Carlos, Araras, SP, entre 8 de janeiro de 2001 e 23 de fevereiro de 2002. Os tratamentos corresponderam a combinações entre duas intensidades (30 e $50 \mathrm{~cm}$ de resíduo) e duas freqüências de desfolha (pastejo iniciado com 95\% e 100\% de interceptação de luz do dossel - IL) e foram alocados às unidades experimentais conforme um delineamento de blocos completos casualizados e arranjo fatorial $2 \times 2$, com 4 repetições. O intervalo médio entre pastejos variou de 23 a 36 dias para os 
tratamentos de $95 \%$ e $100 \%$ IL, respectivamente, durante o período de primavera/verão. Durante o inverno, esses valores variaram de 95 a 186 dias. A altura do pasto em prépastejo foi um parâmetro confiável para ser utilizado como guia de manejo do pastejo baseado em condições de interceptação luminosa, uma vez que apresentou comportamento consistente e uniforme ao longo do período experimental. De forma geral, não houve diferenças entre as taxas de aparecimento e morte de perfilhos entre tratamentos. No entanto, taxas altas de mortalidade foram acompanhadas por taxas altas de aparecimento de perfilhos, com os maiores valores observados durante o período de primavera/verão relativamente a outono/inverno. Alta frequiência (95\% IL) e/ou alta intensidade de desfolha (30 $\mathrm{cm}$ de resíduo) condicionaram a ocorrência de maiores taxas de mortalidade, propiciando uma maior renovação de perfilhos e, assim, um perfil mais jovem da população quando comparados aos tratamentos de desfolha menos freqüente (100\% IL). Não houve diferença em densidade populacional de perfilhos (média de 380 perfilhos $\mathrm{m}^{-2}$ ), indicando que as diferenças em produção de forragem (18.230 a 27.220 $\mathrm{kg} \mathrm{MS} \mathrm{ha}{ }^{-1}$ ) devem ter sido consequência de diferenças em produção por perfilho, com perfilhos jovens sendo mais eficientes no processo produtivo do que perfilhos mais velhos, fato que justificou a maior produção do tratamento 30/95 (27.220 $\left.\mathrm{kg} \mathrm{MS} \mathrm{ha}^{-1}\right)$. A densidade populacional de perfilhos variou com a época do ano, com os maiores valores registrados na época de verão, seguidos por aqueles do outono e primavera (400, $384 \mathrm{e}$ 344 perfilhos $\mathrm{m}^{-2}$, respectivamente). Os maiores valores de massa de forragem $(8.100 \mathrm{~kg}$ MS ha $\left.{ }^{-1}\right)$ e altura em pré-pastejo $(116 \mathrm{~cm})$ ocorreram para os tratamentos que tiveram o pastejo iniciado com 100\% IL comparativamente aos de 95\% (5.400 kg MS ha ${ }^{-1}$ e 89,5 $\mathrm{cm}$, respectivamente), pois estes permitiram um período de crescimento mais longo e, provavelmente, maior acúmulo de hastes e material morto, o que dificultou a manutenção do resíduo de $30 \mathrm{~cm}$. Houve efeito de época do ano para todas as variáveis estudadas, indicando comportamento fortemente estacional do crescimento do capimMombaça. A partir dos resultados obtidos e considerando-se a importância da manutenção de uma alta taxa de renovação de perfilhos para otimização da produção e utilização de forragem, o pastejo deve ser iniciado quando os pastos atingem $90 \mathrm{~cm}$ de altura (95\% IL) e interrompido quando rebaixado a $30 \mathrm{~cm}$. 


\title{
DEMOGRAPHIC PATTERNS OF TILLERING AND HERBAGE PRODUCTION IN MOMBAÇA GRASS PASTURES SUBMITED TO REGIMES OF INTERMITTENT STOCKING
}

\author{
Author: Marina Castro Uebele \\ Adviser: Prof. Dr. Sila Carneiro da Silva
}

\section{SUMMARY}

The optimization of grazing systems cannot be conceived simply as a maximization of the amount of produced herbage or dry matter consumed by grazing animals. It is necessary to take into account factors that condition and determine the persistence and productivity of pastures in order to ensure the ability of plants to replace dead tillers and maintain pasture stability. Against this background, the present experiment aimed at evaluating the effects of four combinations of grazing frequency and intensity on tiller dynamics/population density and herbage production of grazed Mombaça grass pastures to provide a firm basis for planning grazing management strategies that allow for high herbage productivity and utilization, preserving pasture structure within acceptable limits of use and ensuring its persistence. The experiment was carried out at Universidade Federal de São Carlos, Araras, SP, from 8 January 2001 until 23 February 2002. Treatments comprised combinations between two grazing intensities (post-grazing heights of 30 and $50 \mathrm{~cm}$ ) and two grazing frequencies (grazing initiated at $95 \%$ and $100 \%$ canopy light interception - LI), and were assigned to experimental units (2000 $\mathrm{m}^{2}$ paddocks) according to a complete randomized block design, following a $2 \times 2$ factorial arrangement, with 4 replications. The average grazing interval varied from 23 to 36 days for the 95 and 100\% LI treatments, respectively, 
throughout the spring/summer period. During the winter, these intervals ranged from 95 to 186 days. Pre-grazing pasture height was a reliable grazing management guide based on canopy light interception, since it presented a homogeneous and consistent behavior during the entire experiment. There was no difference in tiller appearance and death rates among treatments. High tiller death rates, however, were accompanied by high tiller appearance rates, with higher values recorded during spring/summer in relation to autumn/winter. High grazing frequency (95\% LI) and/or intensity (30 $\mathrm{cm}$ post-grazing height) resulted in the highest tiller death rates, causing a high tiller turnover that generated a younger profile in tiller population density compared to the low frequency treatments $(100 \% \mathrm{LI})$. There was no difference in tiller population density among treatments (average of 380 tillers $\mathrm{m}^{-2}$ ), indicating that differences in herbage production $\left(18,230\right.$ to $\left.27,220 \mathrm{~kg} \mathrm{DM} \mathrm{ha}^{-1}\right)$ must have been consequence of differences in production per tiller, with younger tillers being more productive than older ones, which was the main reason for the highest forage yield of the 30/95 treatment $\left(27,220 \mathrm{~kg} \mathrm{DM} \mathrm{ha}^{-1}\right)$. Tiller population density varied with time of the year, with higher values recorded during summer in relation to autumn and spring $\left(400,384\right.$ e 344 tillers $\mathrm{m}^{-2}$, respectively). The highest values for pre-grazing herbage mass $\left(8,100 \mathrm{~kg} \mathrm{DM} \mathrm{ha}^{-1}\right)$ and pre-grazing pasture height $(116 \mathrm{~cm})$ were recorded for the $100 \%$ LI treatments compared to $95 \% \mathrm{LI}\left(5,400 \mathrm{~kg} \mathrm{DM} \mathrm{ha}^{-1}\right.$ and $89.5 \mathrm{~cm}$, respectively), since they resulted in longer grazing intervals than the $95 \%$ LI treatments. Accumulation of stem and dead material was certainly the main reason for the difference in herbage mass, and made it difficult for grazing pastures down to the target $30 \mathrm{~cm}$ post-grazing height. There was a season effect on all responses studied, indicating a very seasonal growth behavior of Mombaça grass pastures. Based on the results and baring in mind the importance of a high tiller turnover for optimizing herbage production and utilization, grazing must be initiated at $90 \mathrm{~cm}$ pre-grazing height (95\% LI) and stopped at $30 \mathrm{~cm}$ post-grazing height. 


\section{INTRODUÇÃO}

A produção de forragem é um processo contínuo, regulado por variáveis de ambiente e por características da pastagem. A medida que tecidos foliares crescem nas plantas, esses estão sujeitos ao envelhecimento e à senescência, responsáveis pela redução no acúmulo de massa seca e pelas perdas quantitativas e qualitativas da forragem produzida. Em pastagens sob pastejo, folhas sofrem desfolhas sucessivas onde sua frequência e intensidade afetam sobremaneira a fisiologia das plantas e, portanto, a taxa de produção de novas folhas. Assim, a otimização dos sistemas de pastejo não pode ser concebida apenas como a maximização da quantidade de forragem produzida ou ingerida pelos animais de forma independente, mas como o resultado do compromisso entre os três ciclos de fluxo de tecidos em pastagens: crescimento, senescência e consumo.

A eficiência de utilização de forragem em sistemas de pastejo não pode ser analisada apenas em curto prazo através da maximização da razão entre forragem consumida e forragem produzida mas, também, a longo prazo, através da avaliação de parâmetros que condicionam e determinam a persistência e a produtividade da pastagem. Nesse ponto, assegurar a capacidade de reposição de perfilhos, ou seja, das unidades básicas de crescimento de uma pastagem, assume importância fundamental. Para isso, adaptações morfológicas e estruturais da planta forrageira e da pastagem ao regime de pastejo têm que ser consideradas.

Conceitos sobre as interações planta-animal são dominados por estudos em pastagens de azevém perene (Lolium perenne L.), típicas de regiões temperadas, sob um

manejo de pastejo relativamente intensivo. Contudo, é necessário um nível de informação mundial, mais abrangente, sobre o comportamento de espécies de plantas 
com diferentes características morfológicas e fisiológicas, de forma a contribuir para a interpretação funcional sobre o comportamento das plantas forrageiras sob pastejo e permitir a análise da sustentabilidade agronômica e ecológica de pastagens.

Dentro desse contexto, este estudo avaliou os efeitos de diferentes combinações entre intensidade e frequência de desfolha sobre a dinâmica, a densidade populacional de perfilhos e o acúmulo de forragem em pastagens de capim-Mombaça (Panicum maximum Jacq. cv, Mombaça) pastejadas por bovinos, visando determinar estratégias de manejo do pastejo que permitam obter alta produtividade e utilização de forragem, mantendo a estrutura do pasto dentro de limites aceitáveis de uso e garantindo, assim, a sua perenização. 


\section{REVISÃO DE LITERATURA}

\subsection{Plantas Forrageiras em Pastagens}

Plantas em pastagens estão sujeitas a desfolhas sucessivas cuja frequência e intensidade dependem basicamente do sistema de manejo do pastejo adotado. Cada evento de desfolha representa para a planta uma interferência no seu crescimento e na sua habilidade competitiva dentro da população (Lemaire, 2001), de tal forma que as respostas das plantas aos impactos da desfolha são uma tentativa de restabelecer e manter um padrão "homeostático" de crescimento, onde os recursos são utilizados de uma maneira balanceada a fim de atingir um padrão ótimo de crescimento (Lemaire \& Chapman, 1996).

$\mathrm{O}$ interesse pelo conhecimento sobre o crescimento e a produção de forragem em pastagens para fins de manejo da desfolha é antigo. Nos estudos de Brougham (1955) foi determinada a natureza da curva de rebrotamento de pastos consorciados de azevém perene, trevo branco (Trifolium repens L.) e vermelho (Trifolium repens L.), submetidos a desfolhas sucessivas. A curva apresenta três fases distintas. Na primeira fase, as taxas de acúmulo líquido de forragem aumentam exponencialmente com o tempo, pois existe pequena ou nenhuma morte de folhas, sendo o acúmulo líquido de forragem equivalente a taxa líquida de assimilação do dossel. Mesmo quando se inicia o processo de senescência e morte, as primeiras folhas a morrerem são aquelas produzidas no começo da rebrotação; essas são menores do que aquelas produzidas subsequentemente, razão pela qual a taxa de morte de folhas é menor inicialmente em relação a taxa de produção de novos tecidos (Robson et al., 1988), mantendo uma taxa de acúmulo líquido máxima nesse período. Essa fase é altamente influenciada pelas 
reservas orgânicas da planta, disponibilidade de fatores de crescimento e área residual de folhas (Brougham, 1957). A segunda fase apresenta taxa de acúmulo líquido constante a medida que a taxa de morte de tecidos passa a ser equivalente a taxa de produção de novos tecidos. Dessa forma, atinge-se uma produção teto de forragem na pastagem. $\mathrm{O}$ processo de competição inter e intra-específica adquire caráter mais relevante, principalmente quando o dossel vai se aproximando da completa interceptação da luz incidente. Na terceira fase, inicia-se a queda das taxas de acúmulo líquido, causada pela redução na taxa de crescimento e pelo aumento na senescência de folhas, provocada pelo sombreamento (Hodgson et al., 1981).

A fotossíntese bruta de uma pastagem aumenta a medida que se tem um incremento na área de folhas disponível para interceptar a luz por unidade de área de solo (IAF) (Gastal \& Bélanger, 1993). Entretanto, esse aumento é rápido até que se atinja um valor ótimo, a partir do qual o sombreamento causado pelo aumento do IAF leva à redução ou à ausência de luz nas folhas inferiores, induzindo uma diminuição na sua atividade fotossintética. Essas folhas passam da condição de fonte de fotoassimilados para a condição de dreno (Donald,1961; citado por Marshall, 1987). A partir desse ponto, as taxas de fotossíntese e respiração no dossel tornam-se muito próximas. Esse é considerado o IAF “ótimo”, onde a taxa de acúmulo de massa seca do pasto atinge um valor teto, proporcionando o valor máximo de taxa de crescimento da cultura (TCC, massa seca acumulada por unidade de área por unidade de tempo) (Watson, 1958). Aumentos subsequentes no IAF reduzem a taxa de acúmulo do pasto como consequência do aumento nas taxas de respiração, resultante do aumento na quantidade de tecidos sem função fotossintética (senescentes) (Donald, 1961; citado por Marshall, 1987).

Brougham (1956), estudando a influência da intensidade de desfolha sobre as taxas de acúmulo de massa seca subsequentes e a interceptação de luz em pastos de azevém perene consorciado com trevo branco e vermelho sob regime de corte, verificou que o acúmulo de massa seca atingia uma taxa máxima constante que era mantida enquanto existia área foliar suficiente para interceptar quase toda a luz incidente. Outra conclusão foi que uma maior intensidade de desfolha exigia um tempo mais prolongado 
de recuperação, pois a primeira fase da rebrotação se estendia por um período mais longo. Contudo, a produção máxima atingida na curva de crescimento era a mesma de pastos submetidos a cortes menos drásticos.

Após a constatação da interação entre intensidade e frequência de desfolha no manejo das plantas forrageiras, Brougham (1959) passou a estudar o efeito da combinação entre frequência e intensidade em áreas pastejadas, confirmando a necessidade de manejar plantas forrageiras sob pastejo segundo combinações entre esses dois parâmetros.

Wilson \& Mc Guire (1961) e Donald (1961), citado por Marshall (1987), quantificaram a luz que era interceptada pelo dossel de azevém perene, mencionada por Brougham (1960). Os autores encontraram redução na produção total dos pastos quando esses eram desfolhados com menos de $95 \%$ de interceptação luminosa, indicando que as TCC eram reduzidas a medida que a interceptação da luz incidente era incompleta.

Korte et al. (1982) estudaram o comportamento do crescimento de azevém perene testando duas intensidades associadas a duas frequências de desfolha correspondentes a 95\% de interceptação luminosa (IL) e duas semanas depois de atingido esse valor. Os autores concluíram que para a fase de desenvolvimento vegetativo (alertaram para a necessidade de cautela no uso desse critério quando a planta encontrava-se em estádio de desenvolvimento reprodutivo), a frequência de desfolha, caracterizada pelo ponto onde a planta atingia 95\% de IL, seria a mais indicada. Esse valor de IAF no qual $95 \%$ da luz incidente era interceptada e o valor da TCC era próximo do máximo foi definido como IAF “crítico" por Blaser et al. (1986). Demonstrou-se, assim, ao menos para gramíneas de clima temperado, que plantas forrageiras em pastagens têm respostas altamente relacionadas com o tamanho e a qualidade de sua área foliar (IAF) e a consequente interceptação da luz incidente (IL). Esse tipo de evidência, contudo, ainda não foi gerado de forma clara e objetiva para gramíneas de origem tropical e subtropical. 


\section{2 Índice de Área Foliar do Pasto}

O crescimento da planta está condicionado primariamente à obtenção de energia proveniente da radiação solar, através da interceptação de luz e sua utilização no processo de fotossíntese (absorção de carbono). A interceptação de luz é determinada basicamente pela quantidade de folhas existentes no dossel, dependendo, dessa maneira, de características morfogênicas (taxa de emissão de folhas, taxa de expansão da folha e duração da vida da folha) e de condições de meio ambiente que possam afetar essas características (Lemaire \& Chapman, 1996). Dessa forma, determina-se os parâmetros estruturais da pastagem (tamanho das folhas, número de folhas por perfilho e densidade populacional de perfilhos) que resultam no índice de área foliar, ou seja, a área de folhas disponível para interceptar a luz por unidade de área de solo. O IAF associado à disponibilidade de água e nutrientes determina a eficiência de absorção de carbono. Portanto, a manutenção de um IAF ótimo é de fundamental importância, uma vez que permite atingir máximas taxas de crescimento da pastagem (Watson, 1958). Considerando que o número de folhas vivas por unidade de crescimento da planta (perfilho) é relativamente constante e determinado geneticamente, e que o tamanho das folhas sofre uma grande influência do regime de desfolha, o perfilhamento de gramíneas tem sido considerado como o principal agente otimizador do IAF do pasto (Langer, 1963), já que alterações na produção da planta forrageira são efetuadas através de variações em peso e número de perfilhos (Nelson \& Zarrough, 1981; Matthew et al., 1995; Sbrissia et al., 1999).

\subsubsection{Morfogênese}

A morfogênese de plantas pode ser definida como a dinâmica de geração (gênese) e expansão da forma (morfo) da planta no espaço (Chapman e Lemaire, 1993).

É expressa como a taxa de aparecimento e expansão em tamanho de novos órgãos da planta, assim como sua taxa de desaparecimento pela senescência. De acordo com Gillet et al. (1984), pode-se considerar que as plantas têm uma morfogênese geneticamente 
planejada e altamente dependente da temperatura. Esse programa morfogênico determina o funcionamento e a coordenação dos meristemas em termos de taxas de expansão e produção de novas células que, no fim, definem a dinâmica de expansão dos órgãos que crescem (folhas, internódios e perfilhos) e a demanda necessária de carbono e nitrogênio para manter a expansão correspondente (Durand et al., 1991). Dessa forma, o programa morfogênico da planta está associado aos processos externos que determinam o suprimento de assimilados (Lemaire \& Agnusdei, 1999).

A morfogênese é definida em nível individual de planta ou unidade de crescimento, como os perfilhos para as gramíneas. Entretanto, plantas não crescem como indivíduos isolados mas como membros de uma comunidade, onde existe competição entre as plantas e que influencia no seu crescimento e fenologia. Portanto, enquanto a atividade morfogênica pode ser analisada em nível de unidade de crescimento individual (perfilho), a extrapolação para toda a pastagem requer um entendimento sobre as interações competitivas e respostas à remoção de folhas (Lemaire \& Chapman, 1996).

Para uma pastagem vegetativa e onde somente folhas são produzidas, a morfogênese pode ser descrita por três características principais: taxa de aparecimento de folhas (TAF), que é o número de folhas emitidas por unidade de tempo; taxa de expansão de folhas (TEF), que é a medida diária do aumento no comprimento de uma folha individual $\left(\mathrm{mm} \cdot \mathrm{dia}^{-1}\right)$; e longevidade da folha (LF), que é a medida do período de tempo durante o qual a folha permanece verde. Essas características são determinadas geneticamente mas condicionadas por variáveis de ambiente (Lemaire \& Chapman, 1996).

Combinações dessas variáveis morfogênicas elementares determinam as três principais características estruturais de uma pastagem (Lemaire \& Chapman, 1996): (1) tamanho da folha, que é determinado pela razão entre TEF e TAF dado que, para um genótipo, a duração do período de expansão de uma folha é uma fração constante do intervalo entre o aparecimento de folhas sucessivas (Robson, 1967; Dale, 1982);

(2) densidade populacional de perfilhos, que é relacionada à TAF, pois esta determina o número potencial de pontos para o aparecimento de perfilhos (Davies, 1974). Assim, 
genótipos com TAF alta têm um potencial para perfilhamento maior, produzindo pastagens com maior densidade populacional de perfilhos, que aquelas com TAF baixa. (3) número de folhas verdes por perfilho, resultado do produto entre a longevidade de folhas e a TAF.

Assumindo uma razão constante entre área e comprimento de uma folha para um dado genótipo, o produto dessas três características estruturais do dossel determina o índice de área foliar (IAF) da pastagem (Lemaire \& Chapman, 1996), a principal variável estrutural dos pastos e que possui alta correlação com as respostas tanto de plantas como de animais em ambientes de pastagens (Sbrissia \& Da Silva, 2001). Em algumas espécies de plantas tropicais, particularmente aquelas de crescimento ereto, existe um outro componente importante do crescimento que interfere significativamente na estrutura do pasto e nos equilíbrios dos processos de competição por luz, a taxa de alongamento de hastes. Avaliações realizadas com plantas do gênero Cynodon sob lotação contínua revelaram que cerca de 60-75\% do crescimento das plantas era proveniente do alongamento de hastes e não apenas da expansão de folhas (Pinto, 2000). Essa condição poderia propiciar aumentos de IAF e de produção em situações onde o crescimento proveniente somente de folhas, típico de plantas de ambiente temperado, não seria mais efetivo (i.e. períodos de descanso mais longos). No entanto, efeitos potenciais negativos sobre a estrutura do pasto (acúmulo de material morto e hastes, redução da densidade populacional de perfilhos, etc.) ocorreriam de forma concomitante, podendo compensar parcial ou totalmente os benefícios provenientes da maior produção de fitomassa, comprometendo a eficiência de utilização da forragem produzida e a longevidade do pasto (Sbrissia \& Da Silva, 2001).

O fluxo de tecidos num perfilho individual (crescimento e senescência) é melhor entendido quando considera-se a axis do perfilho como sendo uma cadeia sequencial de fitômeros, cada um seguindo uma série pré-programada de estádios de desenvolvimento desde primórdio foliar até órgão maduro e, finalmente, a senescência (Silsbury, 1970).

Após o aparecimento, o perfilho passa a diferenciar-se, expandir folhas e alongar haste a uma velocidade condicionada e determinada por fatores de ambiente, 
nutricionais e genéticos. O número de folhas que permanecem vivas no perfilho é determinado geneticamente, além de ser relativamente constante. Azevém perene, por exemplo, consegue manter três folhas vivas em média por perfilho (Hodgson, 1990), enquanto Coastcross (Cynodon spp. (L.) Pers) mantém cerca de oito folhas vivas por perfilho (Carnevalli \& Da Silva, 1999). Para Mombaça, o número de folhas vivas observado por Santos (1997) foi de 5 a 6. A partir desse número determinado de folhas, a cada nova folha que aparece, a folha mais velha entra em processo de senescência. Para azevém perene, esse ponto coincide com 95\% de interceptação luminosa (IL), ou seja, numa condição em que o pasto se encontra com 3 a $4 \mathrm{~cm}$ de altura e índice de área foliar de 2 a 4, variável conforme a estação do ano (Hodgson, 1990). Já para Tifton-85 (Cynodon spp. (L.) Pers), isso acontece quando o pasto atinge cerca de 15 a $20 \mathrm{~cm}$ de altura e índice de área foliar variando entre 1,5 e 2,7(Fagundes et al., 1999; Pinto, 2000).

A TAF tende a decrescer a medida que o dossel se restabelece após uma desfolha completa. Esse fenômeno pode ser consequência do aumento do comprimento de bainhas de folhas sucessivas, atrasando o aparecimento de novas lâminas no dossel. Portanto, a TAF de pastagens mantidas num IAF baixo por desfolhas frequentes parece ser maior do que a observada em pastagens desfolhadas intermitentemente (Lemaire \& Chapman, 1996). A TEF responde imediatamente a qualquer mudança de temperatura no ápice da parte aérea (Peacock, 1975a; Stoddart et al., 1986). A curva de resposta da TEF em relação a temperatura muda rapidamente durante a transição de crescimento vegetativo para reprodutivo em gramíneas temperadas durante a primavera (Peacock, 1975b; Parsons \& Robson, 1980), resultando num potencial de crescimento muito maior a uma dada temperatura para pastagens em estádio reprodutivo do que para pastagens em estádio vegetativo (Gastal et al., 1992). Por causa da resposta linear da TAF à temperatura, o tamanho da folha (determinado pela razão TEF/TAF) aumenta com o aumento da temperatura e, a uma mesma temperatura, é maior para pastagens em estádio reprodutivo na primavera do que para pastagens vegetativas no verão e outono (Gastal et al., 1992).

A senescência de folhas, assim como a sua longevidade, são afetadas pela temperatura de forma similar à TAF. Portanto, em condições onde a pastagem é mantida 
em um estado constante ('steady state'), um equilíbrio entre aparecimento e morte de folhas é atingido, o que resulta no número máximo de folhas vivas por perfilho (Lemaire \& Chapman, 1996). Esse número de folhas por perfilho corresponde a longevidade das folhas expressa em número de intervalos de aparecimento. Em nível de perfilho, o intervalo de tempo entre o aparecimento de duas folhas sucessivas é chamado 'filocrono', sendo a TAF a razão inversa do filocrono (TAF = 1/filocrono).

Para uma dada espécie, o filocrono é um parâmetro relativamente constante quando expresso em unidades térmicas (graus-dias), fato esse que fornece uma escala de tempo básica para o estudo da morfogênese de plantas (Lemaire \& Agnusdei, 1999). Com a produção de um novo primórdio foliar, o meristema apical produz uma nova gema axilar que potencialmente pode se desenvolver num novo perfilho. Considerando um atraso constante de mais ou menos dois filocronos (ou mais dependendo da espécie) entre o aparecimento de uma dada folha e o aparecimento do novo perfilho correspondente, é possível calcular diretamente o número máximo de perfilhos que pode aparecer durante um filocrono o que, de fato, tem relação com os conceitos de 'sitefilling' (Davies, 1974; Neuteboom e Lantinga, 1989; Van Loo, 1992) e 'site-usage' (Skinner e Nelson, 1992). Como mostrado por Matthew et al. (1991), o filocrono pode também ser utilizado para a análise do aparecimento sequencial de raízes, permitindo que a dinâmica de uma pastagem possa ser descrita e analisada em termos de processos clonais de crescimento. Portanto, com um filocrono de 110 graus-dia e um máximo de três folhas vivas por perfilho, folhas de azevém perene têm uma longevidade de folhas de 330 graus-dia (Lemaire \& Chapman, 1996).

A diferença em longevidade de folhas entre as espécies tem grande influência sobre a sua capacidade de acumular massa de forragem e atingir altas produções teto. Não é o número máximo de folhas vivas por perfilho, contudo, que determina a produção teto de uma pastagem, mas sim a longevidade das folhas, que é bastante relacionada com a temperatura (Lemaire \& Chapman, 1996).

É importante conhecer a longevidade das folhas de diferentes espécies para que se possa desenvolver um manejo eficiente de colheita, pois é a partir dela que se determina a proporção e a quantidade da produção bruta de forragem que pode ser 
efetivamente colhida num programa eficiente de manejo do pastejo (Lemaire \& Chapman, 1996).

\subsection{Perfilhamento}

Perfilhos de gramíneas possuem um ciclo de vida mais ou menos determinado, quando são então substituídos, de maneira organizada, por fitômeros jovens. Essa organização dos perfilhos na forma de uma cadeia sequencial de fitômeros confere aos mesmos duas características importantes: (1) capacidade de substituição de perfilhos que vão morrendo e (2) proteção de meristemas contra o processo de desfolha (Valetine \& Matthew, 1999).

Muitos fatores afetam o perfilhamento das plantas forrageiras. De acordo com Langer (1979), a produção de perfilhos é controlada pela disponibilidade de água, luz, temperatura e nutrientes, principalmente nitrogênio e, em menor escala, fósforo e potássio, além do estádio de desenvolvimento da planta (reprodutivo ou vegetativo). A ação de todos esses fatores em conjunto determina o aparecimento e a morte de perfilhos que acontecem em todos os meses do ano (Langer, 1956). A perenidade de plantas individuais, e consequentemente do pasto, depende da capacidade de substituição dos perfilhos mortos, que também é afetada pelos picos estacionais de morte e aparecimento, especialmente aqueles associados com eventos de florescimento. Se a substituição de perfilhos falhar, a planta morre. Adicionalmente, se a utilização do pasto for incorreta e a morte de perfilhos for consistentemente maior que o aparecimento, o pasto entra em processo de degradação (Marshall,1987).

A morte de perfilhos pode ter diferentes causas. A maior delas é a remoção dos ápices pelos animais em pastejo. Esse fenômeno é particularmente importante em pastagens no estádio reprodutivo, quando os meristemas são elevados pelo alongamento dos internódios das hastes até o horizonte de desfolha. Mas, mesmo em pastagens vegetativas de algumas espécies como azevém perene, o regime de desfolha leniente pode induzir o alongamento dos internódios basais e aumentar o risco de decapitação dos meristemas apicais (Davies, 1988). Algumas gramíneas tropicais são 
particularmente vulneráveis à remoção dos ápices das hastes (Chapman \& Lemaire, 1993). Uma outra causa importante da morte de perfilhos em pastagens densas é o balanço negativo de energia, resultado da competição por luz. Davies et al. (1983) demonstraram que uma quantidade maior de fotoassimilados era alocada para o crescimento de perfilhos existentes em relação àquela alocada para o desenvolvimento de novos perfilhos em plantas sombreadas. Perfilhos jovens são os primeiros a morrer por serem sobrepostos e sombreados por perfilhos maduros (Ong et al., 1978) e algumas gemas de perfilhos são provavelmente abortadas, antes mesmo da emergência de novos perfilhos em dosséis sombreados (Lemaire \& Chapman, 1996).

O equilíbrio entre o aparecimento e a morte de perfilhos é extremamente dependente do regime de desfolha adotado, que por sua vez determina a evolução do IAF, que parece ser o fator chave controlando tanto o aparecimento como a morte de perfilhos (Valantine \& Matthew, 1999). Para grande parte das pastagens de azevém perene manejadas intermitentemente, a densidade populacional de perfilhos aumenta após a desfolha até que um IAF em torno de 3-4 seja atingido, ponto a partir do qual começa a diminuir (Lemaire \& Chapman, 1996). Em manejo caracterizado por lotação contínua, a densidade populacional de perfilhos é determinada principalmente pelo IAF no qual a pastagem é mantida, sendo que pastagens que sofrem desfolhas severas têm maior densidade populacional de perfilhos que pastagens manejadas lenientemente (Grant et al., 1983).

\subsubsection{Compensação tamanho/densidade populacional de perfilhos em pastagens}

Enquanto diferenças em aspectos morfogênicos entre espécies ou cultivares, como a TAF por exemplo, podem determinar todas as características estruturais do pasto, variações no fenótipo expressas por um genótipo em resposta a variações de ambiente e/ou manejo também influenciam sobremaneira a estrutura de uma pastagem. Esse fenômeno é conhecido como plasticidade fenotípica (Bradshaw, 1965) e é importante na adaptação de plantas forrageiras à desfolha, sendo expressa como modificações morfológicas progressivas e reversíveis em plantas individuais. 
Comunidades de plantas em pastagens procuram ajustar-se às diferentes condições e intensidades de desfolha através de mecanismos que visem assegurar sua perenidade e eficiência fotossintética. O principal componente estrutural do pasto sensível a essas adaptações é o IAF (Lemaire \& Chapman, 1996) e uma comunidade de plantas pode otimizá-lo de diversas maneiras. Como abordado anteriormente, a análise dos componentes do IAF mostra que este é composto por três características estruturais distintas do pasto (Matthew et al., 1999): densidade populacional de perfilhos, número de folhas por perfilho e tamanho da folha.

O número de folhas vivas por perfilho é um valor relativamente constante para uma dada espécie (Davies, 1977; Yang et al., 1988; Carnevalli \& Da Silva, 1999). Já a área foliar é determinada basicamente pelo comprimento da folha que, por sua vez, é controlado pela intensidade de desfolha. Dessa forma, a densidade populacional de perfilhos é o componente do IAF que permite a maior flexibilidade de ajuste por parte da planta forrageira a diferentes regimes de desfolha (Matthew et al, 1999).

Se o suprimento de assimilados for menor que a demanda para o crescimento de folhas, a planta limita o número de meristemas ativos (reduz a densidade populacional de perfilhos) para manter o potencial de crescimento de folhas no perfilho principal. Por essa razão, enquanto a taxa de expansão de folhas em perfilhos maduros é muito pouco afetada pelo suprimento de carbono, o perfilhamento é determinado por variações no nível de radiação (Lemaire \& Agnusdei, 1999). O aumento no IAF, por causar alteração na qualidade do ambiente luminoso dentro do dossel, pode modificar algumas variáveis morfogênicas em nível de planta individual, como a TAF e a taxa de perfilhamento e, consequentemente, mudar, também, as características estruturais do pasto, como a densidade populacional e o tamanho dos perfilhos (Deregibus et al.,1983).

A otimização do IAF de um pasto em situações de altura de desfolha baixa é alcançada através de uma alta densidade populacional de perfilhos pequenos (Matthew et al., 1999). Entretanto, com desfolhas drásticas, o IAF do dossel e o suprimento de fotoassimilados podem ser reduzidos ao ponto em que a produção de novos perfilhos é diminuída e a densidade populacional de perfilhos também diminui a medida que os perfilhos existentes morrem (Matthew et al., 1999). Atingido o ponto de máxima taxa 
média de acúmulo líquido de forragem, os fatores de crescimento passam a ser limitantes dentro do dossel, acentuando-se o processo de competição entre os perfilhos. O fator de maior competição, sob condições ótimas, é a luz. A ativação de gemas e a produção de novos perfilhos é dada pela alta razão vermelho: infra vermelho da radiação incidente, e essa razão é reduzida à medida que se aumenta a área foliar do dossel (Matthew et al., 1999). Provavelmente, devido a isso, a produção de novos perfilhos pára antes da área foliar de equilíbrio ser alcançada. O resultado é uma trajetória curvilínea de tamanho/densidade populacional de perfilhos durante a rebrotação à medida que, primeiramente, a densidade populacional de perfilhos aumenta, depois mantém-se constante e depois diminui ao longo de uma linha limítrofe de máxima área foliar para um dado ambiente (Matthew et al., 1999). Em nível de comunidade de plantas, portanto, os perfilhos surgem, crescem, aumentam em tamanho e promovem um "auto-desbaste" em perfilhos mais fracos, localizados em pontos mais próximos do nível do solo, onde há um ambiente de baixa luminosidade. Quanto maior o tamanho do perfilho, um menor número de perfilhos pode ser mantido na área (Hodgson,1990).

A relação inversa entre densidade populacional e tamanho individual de perfilhos em comunidades pastejadas de plantas forrageiras tem sido descrita para muitas pastagens de gramíneas (Grant et al., 1983; Lambert et al., 1986; Davies, 1988). Em relvados que não sofreram desfolha, a compensação tamanho/densidade foi observada segundo uma reta de inclinação $-3 / 2$, exceto em condições de nível baixo de luminosidade (Kays \& Harper, 1974; Lonsdale \& Watkinson, 1982). Tem-se assumido, genericamente, que pastos sob desfolha deveriam seguir a mesma lei (Bircham \& Hodgson, 1983; Lambert et al., 1986; Xia, 1991). No entanto, análise visual dos dados de Davies (1988) sugeriu uma sistemática falta de ajuste à inclinação teórica de -3/2. Matthew (1992) também observou inclinação maior que -3/2 em pastos de azevém perene sob desfolha. Matthew et al. (1995) argumentaram que em pastos sob desfolha um diagrama multifásico de compensação tamanho/densidade seria esperado, isto é, existiriam 4 fases, cada uma delas representando diferentes situações do estado da pastagem. Segundo esses autores, as 4 fases seriam: (1) massa de forragem baixa (tamanho pequeno de perfilhos) - nível de energia no perfilho seria baixo e o pasto teria 
aparecimento de novos perfilhos insuficiente para atingir a linha $-3 / 2$ de auto-desbaste através do aumento no número de perfilhos; (2) área foliar variável (fase de rebrotamento) - auto-desbaste a uma inclinação -5/2; (3) área foliar constante - autodesbaste a uma inclinação -3/2; e (4) massa de forragem constante (situação hipotética) - auto-desbaste a uma inclinação -1. O ponto de transição entre as fases (2) e (3) seria considerado como um indicador da altura de pasto ideal para uma determinada espécie ou cultivar, uma vez que se a rebrotação prosseguisse além desse ponto a perda de perfilhos passaria a ser maior para um aumento correspondente em massa de forragem (Sbrissia \& Da Silva, 2001).

O equilíbrio é claramente dinâmico e as respostas compensatórias entre tamanho e densidade populacional de perfilhos, como consequência do regime de desfolha, resultam em pequenas diferenças na quantidade total de folhas produzidas por unidade de área, como foi demonstrado em estudos com pastagens manejadas através de lotação contínua mantidas a diferentes alturas de dossel (Grant et al., 1981, 1983; Bircham \& Hodgson, 1983). Resultados semelhantes em termos de produção de folhas por unidade de área também foram obtidos quando variações em tamanho/densidade populacional de perfilhos tinham origem genética, como mostrado por Mazzanti et al. (1994) na comparação entre dois cultivares de Festuca arundinacea (Schreb).

A discussão sobre plasticidade fenotípica de gramíneas e leguminosas leva ao conceito de limites da resposta plástica (Briske, 1996) das plantas forrageiras, e a considerações de como esses limites podem ser definidos e utilizados para relacionar espécies forrageiras ou genótipos ao melhor regime de desfolha e, dessa forma, otimizar o crescimento do pasto no longo prazo, dentro da heterogeneidade temporal e espacial das pastagens (Lemaire \& Chapman, 1996). Esses limites podem determinar uma série de alternativas de manejo do pastejo, dentro das quais a compensação entre, por exemplo, tamanho e densidade populacional de unidades de crescimento individuais, possa operar para manter uma produção de forragem ótima. Da mesma forma, o conhecimento dos limites plásticos de uma espécie ou cultivar é importante para que esses não sejam transpostos, o que poderia levar ao colapso da condição de equilíbrio da 
pastagem e iniciar rapidamente um processo de degradação se correções rápidas no manejo da desfolha não forem realizadas (Matthew et al., 1995).

\subsubsection{Variações estacionais em densidade populacional de perfilhos}

Experimentos comparando diferentes frequências e intensidades de desfolha geralmente parecem superficiais para explicar mudanças na densidade populacional de perfilhos. Na maioria das gramíneas, a vida média de um perfilho é menor do que um ano e, por isso, é esperado que variações estacionais de energia luminosa provoquem variações na linha limítrofe de área foliar e, com isso, variações estacionais na densidade populacional de perfilhos (Matthew et al., 1999). A persistência de uma pastagem é definida como a manutenção da população de plantas e sua produção ao longo do tempo, mesmo considerando as interferências estacionais e de manejo (Matthew et al., 1999). Muitas espécies de plantas possuem um padrão estacional de aparecimento e morte de perfilhos. A maior variação estacional característica da estratégia de perenização de plantas forrageiras está geralmente associada a fenômenos de florescimento. Existem diferenças entre espécies e até mesmo entre cultivares quanto ao padrão estacional, assim como diferenças inexplicáveis na densidade populacional entre anos sucessivos considerando-se uma mesma espécie ou cultivar (Matthew et al., 1999). Estudos sobre demografia de populações de perfilhos parecem ser uma boa ferramenta para se prever essas variações e, com isso, determinar uma estratégia de manejo do pastejo adequada para manter uma densidade populacional de perfilhos que vise a otimização da produção de forragem ao longo do ano (Lemaire \& Chapman, 1996).

Várias metodologias de monitoramento da dinâmica de perfilhamento têm sido empregadas nos estudos sobre demografia de perfilhos. No caso mais simples, a contagem do número de perfilhos por planta ou da população de perfilhos em tempos regulares é utilizada, e para muitos objetivos isso é tudo que se requer. Para estudos mais detalhados, o monitoramento de perfilhos marcados permite que mudanças na densidade populacional sejam explicadas através do aparecimento e morte de perfilhos. Adicionalmente, maior nível de detalhamento pode ser obtido através do monitoramento 
da sobrevivência de gerações sucessivas de perfilhos marcados em áreas fixas ao longo de um dado período de tempo. Como refinamento, para uma análise demográfica completa, é necessário não só monitorar-se a sobrevivência, mas também a organização hierárquica das gerações de perfilhos surgidas. Essa técnica requer geralmente o corte dos perfilhos das áreas de monitoramento, o que exige um número muito grande de áreas de amostragem (Matthew et al., 1999).

Matthew et al. (1999) sumarizaram treze experimentos detalhados sobre demografia de perfilhos através de diagramas. Pela análise desses diagramas, ficou claro que em muitos casos existiu um aumento ou diminuição estacional distinto nas taxas de aparecimento e morte de perfilhos, que poderia estar associado a estratégias de persistência das plantas, e que esses padrões eram diferentes entre espécies de gramíneas. Para a espécie Phleum pratense L. (Jewiss, 1966), a análise do diagrama revelou um mecanismo de persistência que Matthew et al. (1993) denominaram mecanismo "reprodutivo", pois a renovação da pastagem ocorreu principalmente em associação com o florescimento, e a maioria dos perfilhos de reposição foi formada na base de perfilhos reprodutivos que haviam sido decapitados. Para Festuca arundinaceae (Jewiss, 1966), observou-se uma estratégia de persistência baseada em altas taxas de aparecimento de perfilhos na primavera, perfilhos esses que apresentavam uma tendência de persistir até o florescimento do próximo ano. Já o cultivar Lolium multiflorum cv. 'S22' Lam apresentou alta mortalidade de perfilhos jovens durante o período de verão, fato esse atribuído ao florescimento de perfilhos não vernalisados (Matthew et al, 1999). Para Paspalum notatum Flugge (Pakiding \& Hirata, 1998), observou-se uma estratégia de persistência pela qual novos perfilhos eram formados numa taxa praticamente constante ao longo do ano, supostamente a maioria desses tendo sido originada de perfilhos não florescidos. Uma estratégia similar foi observada para Lolium perenne cv. 'Grasslands Ruanui' (Matthew,1992), caracterizada por Matthew et al. (1993) como um mecanismo "vegetativo" de persistência. Entretanto, apesar da similaridade de padrão de renovação, perfilhos de Paspalum notatum apresentaram uma vida média mais longa (321-902 dias) do que perfilhos de Lolium perenne cv. 'Grasslands Ruanui’ (aproximadamente 90-150 dias). 


\subsubsection{Manipulação da estacionalidade da demografia populacional de perfilhos para fins de manejo do pastejo.}

O conhecimento das estratégias de perenização de cultivares ou espécies forrageiras permite a identificação de regimes de manejo do pastejo que aumentem a produtividade por permitir que o ciclo natural de reposição de perfilhos seja potencializado, assegurando condição para que a população de plantas possa ajustar-se de forma rápida aos regimes de desfolha impostos e restaurar seu IAF "ideal" para uma dada localidade e época do ano (Valantine \& Matthew, 1999). A manipulação da dinâmica de perfilhos numa pastagem deve ser um dos objetivos do manejo do pastejo, principalmente em situações onde a densidade populacional de perfilhos tende para um mínimo necessário para garantir a perenização da pastagem (Lemaire \& Chapman, 1996).

A partir da análise de dados sobre demografia de perfilhos, Matthew et al. (1999) observaram que pastejos mais lenientes na primavera aumentaram consistentemente a renovação da população de perfilhos no verão, talvez por permitir que os perfilhos atingissem um maior tamanho, favorecendo o seu florescimento e, com isso, aumentando a magnitude do evento de renovação no segundo, comparado ao primeiro, ano após o estabelecimento do pasto.

Para Lolium perenne cv. 'Ellett', na Nova Zelândia, grande renovação de perfilhos foi associada ao florescimento e, por isso, $52 \%$ da sua população de perfilhos em meados de dezembro era composta de perfilhos novos, formados a partir da base de perfilhos reprodutivos. Reconhecendo essa estratégia particular de perenização dos modernos cultivares de Lolium perenne na Nova Zelândia, uma série de experimentos foi realizada visando determinar-se um manejo do pastejo que permitisse aumentar o processo de reposição de perfilhos. Em nível de planta, a decapitação atrasada dos perfilhos reprodutivos na primavera aumentou a produção de perfilhos filhos a partir da base de perfilhos reprodutivos, quando comparado com a decapitação mais precoce ou a não decapitação; e a desfolha mais leniente favoreceu a produção de perfilhos filhos relativamente a desfolha drástica (Matthew, 1992; Da Silva et al., 1994). Essas respostas 
foram relacionadas à maior transferência de radiocarbono dos perfilhos pais para os perfilhos filhos (Matthew et al., 1991; Matthew, 1992). Em nível de pastagem, o relaxamento da pressão de pastejo na primavera visando permitir o acúmulo de substrato nos perfilhos em florescimento antes da desfolha, aumentou consistentemente a densidade populacional de perfilhos no final do verão e a produtividade de forragem em 0,9 t MS ha ${ }^{-1}$ em média, considerando-se cinco experimentos separados.

A espécie Bromus willdenowii Kunth utiliza o mecanismo "reprodutivo" de perenização, ou seja, possui uma alta porcentagem de florescimento e a sua persistência depende da formação de perfilhos de reposição no início do verão. Um pastejo severo no início de outubro, um pouco antes do alongamento de hastes, prejudicou a reposição de perfilhos. Assim, a estratégia de atrasar a desfolha por um mês nesse período, e depois realizar um pastejo severo, permitiu um perfilhamento vigoroso a partir da base de perfilhos florescidos decapitados e uma população adequada de perfilhos para a próxima estação. A realização de uma desfolha leniente no início de outubro provocou uma resposta intermediária. Como consequência, a produção de massa seca em um período de 13 meses a partir outubro até novembro do próximo ano foi de 8,7, 16,5 e 12,8 t MS $\mathrm{ha}^{-1}$ para os tratamentos com desfolha "severa", "severa mas atrasada" e "leniente", respectivamente (Black e Chu, 1989).

Black \& Chu (1989) mostraram que para Bromus willdenowii um manejo baseado na associação entre desfolha severa seguida de desfolha leniente aumentou o aparecimento de perfilhos e a produção de forragem no verão, quando comparado a ambos os tratamentos de desfolha severa e leniente separadamente. Da mesma forma, Lemaire \& Culleton (1989) mostraram que um manejo de desfolha no outono associado a um suprimento adequado de nitrogênio pode aumentar o perfilhamento durante o inverno e o subsequente crescimento da pastagem na primavera para Festuca arundinacea.

Os resultados gerais dos estudos de demografia do perfilhamento apontam o potencial que a manipulação das taxas de aparecimento e morte de perfilhos pode ter sobre a produção de forragem. Pouca ou nenhuma informação é disponível para gramíneas tropicais, especialmente Panicum maximum, uma das espécies mais 
produtivas que se conhece. Assim, o presente estudo procurou avaliar os padrões demográficos de perfilhamento de pastos de capim-Mombaça submetidos a regimes de desfolha intermitente. 


\section{MATERIAL E MÉTODOS}

\subsection{Material}

\subsubsection{Local e período do experimento}

O experimento foi realizado utilizando-se o capim da espécie Panicum maximum Jacq. cv Mombaça. A área experimental faz parte do sistema de produção animal do Departamento de Ciência Animal da Universidade Federal de São Carlos, situada no município de Araras/SP, a $22^{\circ} 18^{\prime}$ de latitude sul e $47^{\circ} 23^{\prime}$ de longitude oeste. Os pastos foram estabelecidos em 1998 e o período experimental foi de 8 de janeiro de 2001 a 23 de fevereiro de 2002, com duração de 411 dias.

\subsubsection{Dados climáticos}

Os dados climáticos referentes ao período experimental e as médias mensais dos últimos 30 anos são apresentadas nas Figuras 1 e 2. Esses dados foram obtidos no Posto Meteorológico da Universidade Federal de São Carlos, campus de Araras, distante cerca de 500 metros da área experimental. Na Figura 3 é apresentado o balanço hídrico correspondente aos meses de realização do experimento. 


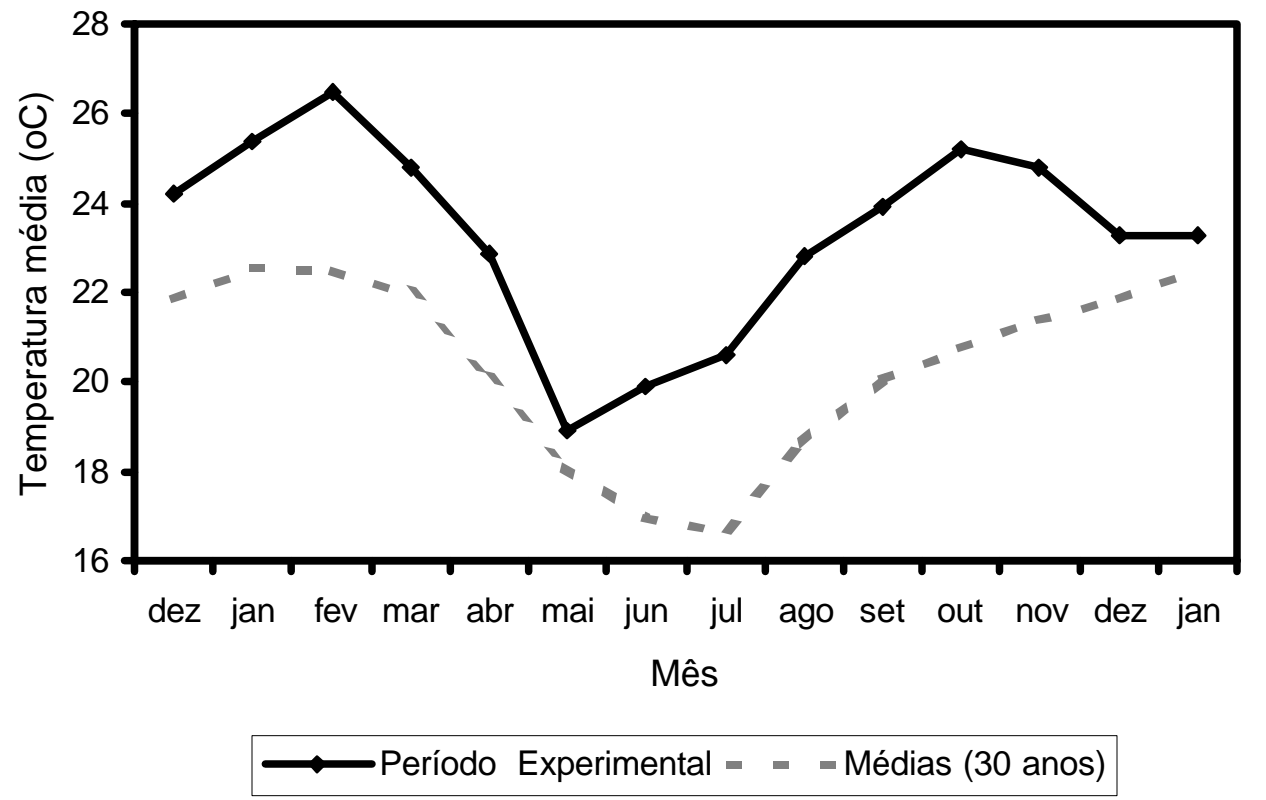

Figura 1 - Distribuição das temperaturas médias durante o período experimental e nos últimos 30 anos.

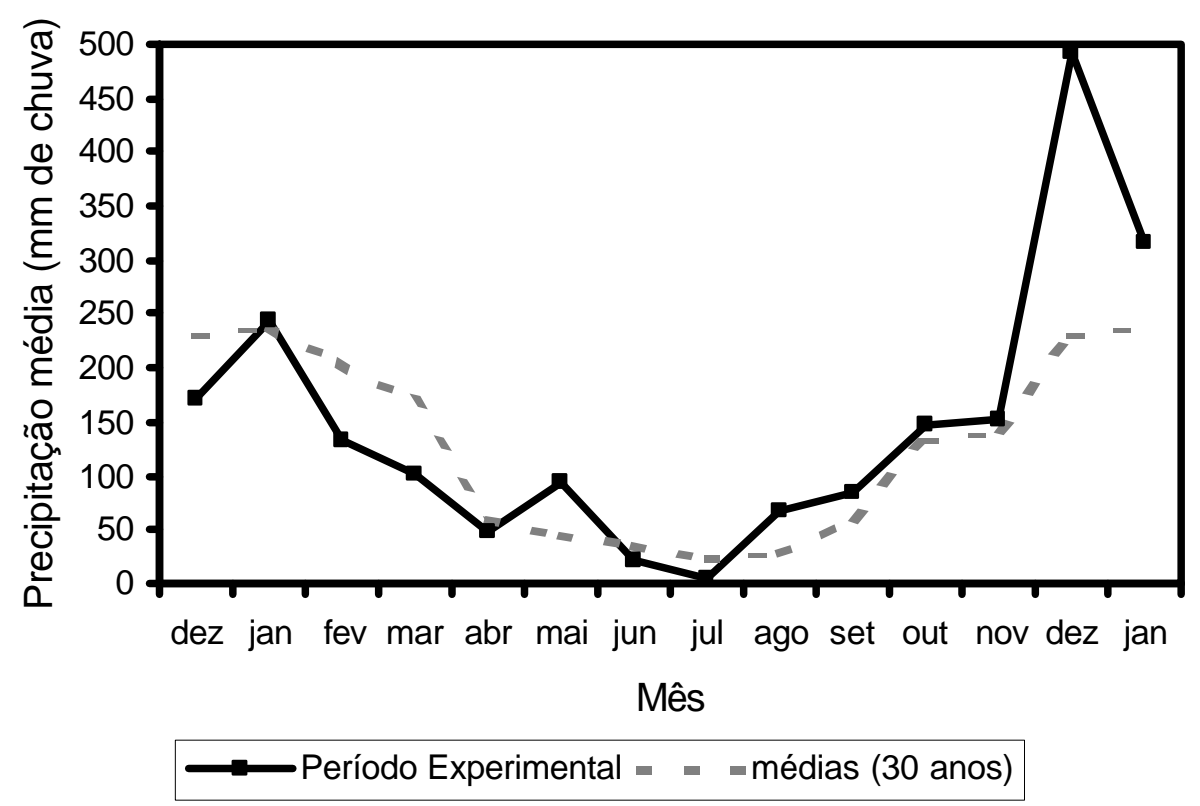

Figura 2 - Distribuição da precipitação durante o período experimental e nos últimos 30 anos. 


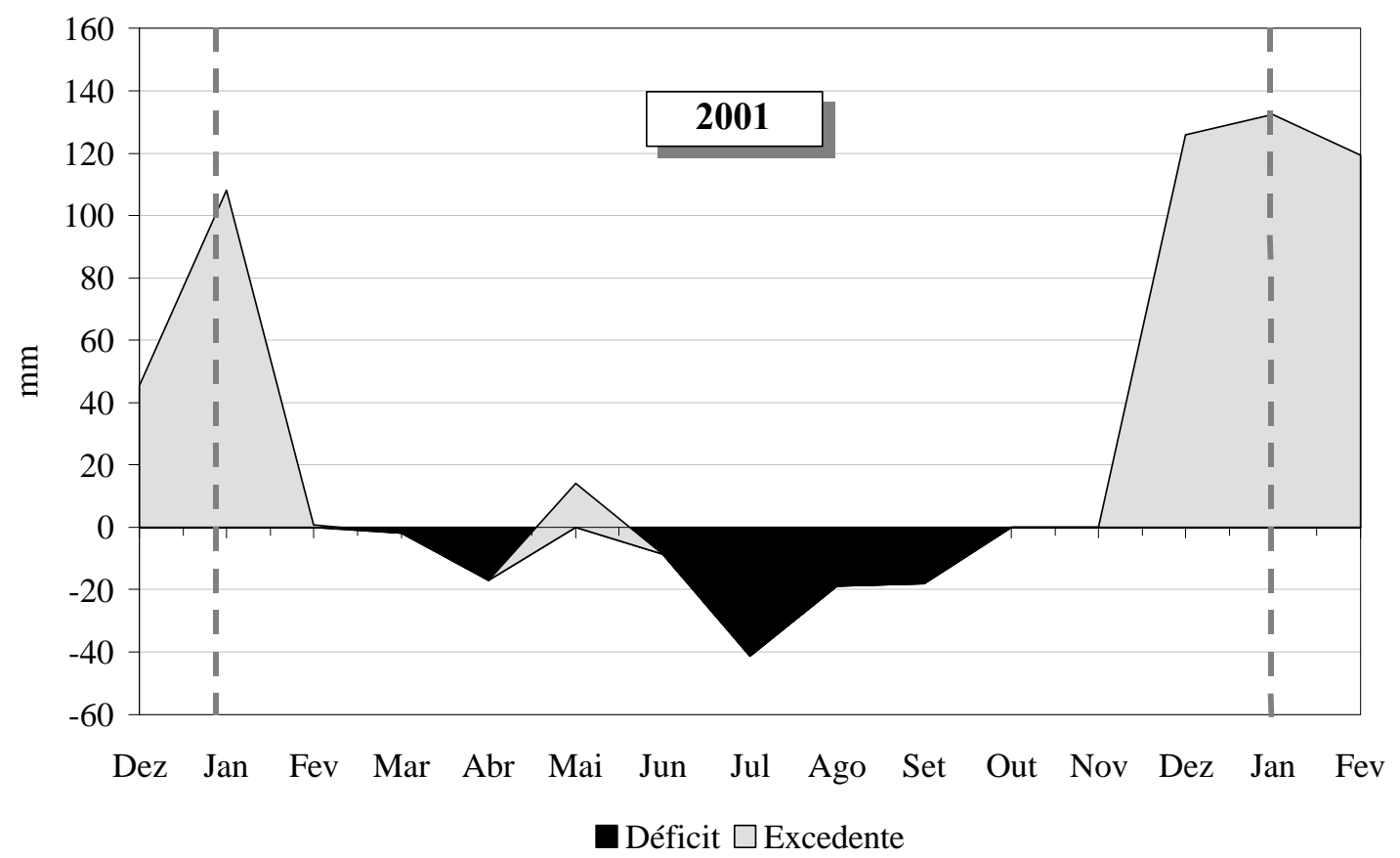

Figura 3 - Balanço hídrico da área experimental de janeiro 2001 a fevereiro de 2002.

\subsubsection{Solo da área experimental}

O experimento foi instalado em solo classificado como Argissolo Vermelho distrófico latossólico (PVd) (EMBRAPA, 1999) de textura muito argilosa, e com horizonte A moderado. A análise de terra revelou um nível de fertilidade médio (Tabela 1). De uma forma geral os piquetes dentro de bloco encontravam-se relativamente homogêneos quanto aos níveis de fósforo e saturação por bases, exceção ao piquete número 5 , bloco 2 , que recebeu $250 \mathrm{~kg} \cdot \mathrm{ha}^{-1}$ de superfosfato simples, com a finalidade de elevar o teor de fósforo para $13 \mathrm{mg} \cdot \mathrm{dm}^{-3}$. 
Tabela 1. Resultado da análise de terra realizada em setembro de 2000.

\begin{tabular}{|c|c|c|c|c|c|c|c|c|c|c|}
\hline Piquete & $\begin{array}{c}\mathrm{P} \\
\mathrm{mg} \cdot \mathrm{dm}^{-3}\end{array}$ & $\begin{array}{l}\text { M.O. } \\
\text { g.dm }\end{array}$ & $\begin{array}{c}\mathrm{pH} \\
\mathrm{CaCl}_{2}\end{array}$ & \multicolumn{6}{|c|}{$\mathrm{mmol}_{\mathrm{c}}$} & $\begin{array}{l}\mathrm{V} \\
\%\end{array}$ \\
\hline \multicolumn{11}{|c|}{ Bloco 1} \\
\hline 1 & 7 & 29 & 5,1 & 1,8 & 26 & 15 & 33 & 43,1 & 75,6 & 57 \\
\hline 2 & 9 & 27 & 5,2 & 1,4 & 28 & 13 & 33 & 42,5 & 75,0 & 57 \\
\hline 3 & 8 & 24 & 4,7 & 1,6 & 21 & 12 & 42 & 35,2 & 77,5 & 45 \\
\hline 4 & 7 & 25 & 5,1 & 0,9 & 23 & 11 & 33 & 35,4 & 67,9 & 52 \\
\hline \multicolumn{11}{|c|}{ Bloco 2} \\
\hline 5 & 8 & 25 & 5,4 & 2,5 & 22 & 16 & 26 & 40,3 & 66,6 & 60 \\
\hline 6 & 19 & 32 & 5,8 & 3,7 & 30 & 19 & 22 & 52,7 & 75,2 & 70 \\
\hline 7 & 13 & 35 & 5,5 & 2,7 & 39 & 18 & 29 & 60,0 & 89,2 & 67 \\
\hline 8 & 13 & 35 & 5,3 & 2,1 & 34 & 13 & 33 & 49,6 & 82,1 & 60 \\
\hline \multicolumn{11}{|c|}{ Bloco 3} \\
\hline 9 & 5 & 32 & 5,2 & 1,9 & 22 & 12 & 34 & 35,8 & 70,1 & 51 \\
\hline 10 & 7 & 37 & 5,3 & 1,9 & 24 & 15 & 31 & 40,4 & 71,3 & 57 \\
\hline 11 & 6 & 33 & 5,1 & 2,1 & 26 & 14 & 38 & 42,5 & 80,6 & 53 \\
\hline 12 & 6 & 40 & 5,6 & 2,6 & 29 & 17 & 28 & 48,9 & 76,6 & 64 \\
\hline \multicolumn{11}{|c|}{ Bloco 4} \\
\hline 13 & 6 & 37 & 5,4 & 1,1 & 44 & 14 & 33 & 59,1 & 91,6 & 65 \\
\hline 14 & 8 & 38 & 5,8 & 2,3 & 45 & 18 & 25 & 64,6 & 89,6 & 72 \\
\hline 15 & 8 & 41 & 5,6 & 1,7 & 58 & 22 & 29 & 82,0 & 11,2 & 74 \\
\hline 16 & 8 & 37 & 5,5 & 1,2 & 40 & 18 & 28 & 59,5 & 87,2 & 68 \\
\hline
\end{tabular}

\subsection{Métodos}

\subsubsection{Delineamento experimental e tratamentos}

Os tratamentos foram alocados às unidades experimentais (piquetes) conforme um delineamento de blocos completos casualizados e arranjo fatorial 2 x 2, com 4 repetições. A análise de variância dos dados foi realizada segundo o procedimento MIXED do pacote estatístico SAS (Statistical Analysis System) (SAS Institute, 1989), versão 6.12 para Windows. As médias foram comparadas através do "LSMEANS", adotando-se o nível de $10 \%$ de significância. Análises de regressão entre densidade populacional de perfilhos de cada geração e número de dias de realização do experimento foram feitas através do procedimento PROC REG. Para os dados de acúmulo total de forragem a análise de variância foi feita através do procedimento PROC GLM. 
Os tratamentos corresponderam a duas intensidades combinadas a duas frequências de desfolha. Uma desfolha intensa, julgada apresentar um nível de utilização de forragem alto, com um resíduo de $30 \mathrm{~cm}$ de altura, e uma desfolha mais leniente, deixando-se um resíduo de $50 \mathrm{~cm}$ de altura. Essas intensidades foram combinadas a duas frequências, uma correspondente ao tempo necessário para que a planta atingisse um índice de área foliar (IAF) tal que permitisse que $95 \%$ da luz incidente fosse interceptada, e outra quando atingia-se valores próximos de $100 \%$ de interceptação luminosa. A distribuição das unidades experimentais (piquetes) na área experimental (layout) é apresentada na Figura 4.

\begin{tabular}{|c|c|c|c|c|c|c|c|c|}
\hline $50 / 100$ & $30 / 100$ & $50 / 95$ & $50 / 100$ & $30 / 95$ & $30 / 100$ & $50 / 95$ & $30 / 100$ & $50 / 100$ \\
\hline 6 & 7 & 8 & 9 & 10 & 11 & 12 & 13 & 14 \\
\hline $30 / 95$ & & & & & & & & $30 / 95$ \\
\hline 5 & & & & & & & & 15 \\
\hline $50 / 100$ & & & & & & & & $50 / 95$ \\
\hline 4 & & & & & & & & 16 \\
\hline
\end{tabular}

\section{Bloco 1 Bloco 2 Bloco 3 Bloco 4}

Figura 4 - Representação esquemática da área experimental (*Tratamento = resíduo / interceptação luminosa).

Em setembro de 2000 os piquetes começaram a ser manejados de forma rotacionada e com resíduo de $30 \mathrm{~cm}$ em toda a área experimental. Em dezembro, foram implementados os resíduos correspondentes aos tratamentos $(30$ e $50 \mathrm{~cm}$ ) em cada 
piquete. Como não havia controle, ainda, da frequência de pastejos, houve dificuldades de manutenção dos resíduos propostos, o que levou à necessidade de algumas roçadas manuais após o primeiro pastejo de janeiro de 2001, quando do início do período experimental. Essas roçadas tiveram a finalidade de assegurar que as alturas de resíduo fossem geradas adequadamente, sendo que nos pastejos subsequentes esse tipo de intervenção não foi mais utilizado.

\subsubsection{Monitoramento das condições experimentais e adubação dos pastos}

O monitoramento da interceptação luminosa foi realizado a cada incremento de $20 \mathrm{~cm}$ na altura do pasto após o pastejo $(50,70,90$, etc...) e a cada 2 dias a medida que atingia-se 90\% de interceptação de luz, utilizando-se um aparelho analisador de dossel marca LI-COR modelo LAI 2000 (LI-COR, Lincoln, Nebraska, EUA). Foram utilizadas 6 estações de leitura (amostragem) por piquete, compostas de 5 leituras no nível do solo com uma leitura correspondente acima do nível do dossel em cada estação, totalizando 30 leituras por unidade experimental. Esse número de leituras foi obtido através de simulações do número de estações necessárias em um pré-experimento, sendo que 30 resultou em repetibilidade e precisão satisfatória dos resultados.

Os piquetes experimentais receberam adubações nitrogenadas após cada pastejo, diferenciadas por ciclo de pastejo, totalizando $195 \mathrm{~kg} \cdot \mathrm{ha}^{-1}$ de nitrogênio ao final do experimento. Como o intervalo entre pastejos não era fixo, e a condição de entrada dos animais no pasto era também variável, essa quantidade foi dividida por pastejo conforme o período de descanso resultante de cada tratamento, de tal forma que uma quantidade relativamente uniforme por piquete fosse aplicada por mês (Tabela 2). 
Tabela 2. Relação da quantidade de $\mathrm{N}\left(\mathrm{kg}_{\mathrm{a}} \mathrm{ha}^{-1}\right)$ aplicada por adubação em cada repetição e a respectiva data de adubação* durante o período experimental.

\begin{tabular}{|c|c|c|c|c|c|c|c|c|}
\hline \multirow[b]{2}{*}{ Trat. ** } & \multicolumn{2}{|c|}{ Bloco 1} & \multicolumn{2}{|c|}{ Bloco 2} & \multicolumn{2}{|c|}{ Bloco 3} & \multicolumn{2}{|c|}{ Bloco 4} \\
\hline & data & kg.ha ${ }^{-1}$ & data & kg.ha' ${ }^{-1}$ & data & kg.ha ${ }^{-1}$ & data & kg.ha $^{-1}$ \\
\hline \multirow{7}{*}{$30 / 95$} & $11 / 01$ & 15 & $20 / 01$ & 15 & $27 / 01$ & 15 & $16 / 01$ & 15 \\
\hline & $14 / 02$ & 30 & $17 / 02$ & 30 & $03 / 03$ & 30 & $16 / 02$ & 15 \\
\hline & $21 / 04$ & 50 & $21 / 03$ & 30 & $08 / 04$ & 50 & $22 / 03$ & 30 \\
\hline & $07 / 11$ & 60 & $10 / 04$ & 50 & $04 / 04$ & 60 & $12 / 04$ & 50 \\
\hline & $28 / 11$ & 20 & $26 / 10$ & 30 & $3 / 12$ & 20 & $10 / 10$ & 45 \\
\hline & $31 / 12$ & 20 & $03 / 11$ & 20 & $23 / 12$ & 20 & $03 / 11$ & 20 \\
\hline & & & $30 / 12$ & 20 & & & & \\
\hline & \multicolumn{2}{|c|}{ Bloco 1} & \multicolumn{2}{|c|}{ Bloco 2} & \multicolumn{2}{|c|}{ Bloco 3} & \multicolumn{2}{|c|}{ Bloco 4} \\
\hline \multirow{8}{*}{$30 / 100$} & data & kg.ha ${ }^{-1}$ & data & kg.ha ${ }^{-1}$ & data & kg.ha ${ }^{-1}$ & data & kg.hat \\
\hline & 08/01 & 15 & $19 / 01$ & 15 & $27 / 01$ & 15 & $18 / 01$ & 15 \\
\hline & $22 / 02$ & 30 & $21 / 02$ & 30 & $10 / 03$ & 30 & $11 / 03$ & 30 \\
\hline & $07 / 04$ & 50 & $03 / 04$ & 50 & $23 / 04$ & 50 & $26 / 04$ & 50 \\
\hline & $27 / 11$ & 60 & $20 / 11$ & 60 & $20 / 11$ & 60 & $15 / 11$ & 60 \\
\hline & $08 / 01 / 02$ & 40 & $03 / 01 / 02$ & 40 & $22 / 12$ & 40 & $12 / 01 / 02$ & 40 \\
\hline & \multicolumn{2}{|c|}{ Bloco 1} & \multicolumn{2}{|c|}{ Bloco 2} & \multicolumn{2}{|c|}{ Bloco 3} & \multicolumn{2}{|c|}{ Bloco 4} \\
\hline & data & kg.ha ${ }^{-1}$ & data & kg.hat ${ }^{-1}$ & data & kg.ha ${ }^{-1}$ & data & kg.ha $^{-1}$ \\
\hline \multirow{7}{*}{$50 / 95$} & 09/01 & 15 & $20 / 01$ & 15 & $27 / 01$ & 15 & $17 / 01$ & 15 \\
\hline & $02 / 02$ & 15 & $17 / 02$ & 30 & $24 / 02$ & 30 & $08 / 02$ & 15 \\
\hline & $24 / 03$ & 30 & $23 / 03$ & 30 & $19 / 04$ & 50 & $06 / 03$ & 30 \\
\hline & $26 / 04$ & 50 & $21 / 04$ & 50 & $16 / 10$ & 60 & $03 / 04$ & 50 \\
\hline & $01 / 11$ & 45 & $06 / 10$ & 30 & $14 / 11$ & 20 & $04 / 10$ & 45 \\
\hline & $28 / 11$ & 20 & $05 / 12$ & 20 & $05 / 12$ & 20 & $03 / 12$ & 20 \\
\hline & $21 / 12$ & 20 & $31 / 12$ & 20 & & & $27 / 12$ & 20 \\
\hline & \multicolumn{2}{|c|}{ Bloco 1} & \multicolumn{2}{|c|}{ Bloco 2} & \multicolumn{2}{|c|}{ Bloco 3} & \multicolumn{2}{|c|}{ Bloco 4} \\
\hline \multirow{7}{*}{$50 / 100$} & data & kg.ha ${ }^{-1}$ & data & kg.ha ${ }^{-1}$ & data & kg.ha ${ }^{-1}$ & data & kg.ha $^{-1}$ \\
\hline & $13 / 01$ & 15 & $20 / 01$ & 15 & $27 / 01$ & 15 & $17 / 01$ & 15 \\
\hline & $14 / 02$ & 30 & $19 / 02$ & 30 & $05 / 03$ & 30 & $12 / 02$ & 15 \\
\hline & $30 / 04$ & 50 & $25 / 03$ & 30 & $23 / 01$ & 50 & $28 / 03$ & 30 \\
\hline & $12 / 11$ & 60 & $24 / 04$ & 50 & $05 / 11$ & 60 & $30 / 04$ & 50 \\
\hline & $22 / 12$ & 40 & 08/01 & 30 & $10 / 12$ & 40 & $12 / 11$ & 45 \\
\hline & & & $28 / 11$ & 20 & & & $18 / 12$ & 20 \\
\hline
\end{tabular}

*Nitrogênio aplicado na forma de 20-05-20.

**Tratamento $=$ resíduo $(\mathrm{cm}) /$ interceptação de luz $(\%)$. 


\subsubsection{Padrões demográficos de perfilhamento}

Para a avaliação dos padrões demográficos de perfilhamento e suas respectivas taxas de aparecimento, mortalidade e sobrevivência de perfilhos, as unidades de amostragem (quatro touceiras por piquete) foram alocadas cada uma em um dos cantos da unidade experimental (piquete), em pontos onde a condição da pastagem refletia a condição média do pasto. Em janeiro de 2001 foi iniciado o período experimental, quando todos os perfilhos contidos nas unidades de amostragem (touceiras) foram contados e marcados com arames revestidos de plástico da cor branca. A cada nova amostragem, que aconteceu ao final de cada pastejo, novos perfilhos eram marcados com cores diferentes (Figura 5). Dessa forma, obteve-se a estimativa da população de perfilhos de todas as gerações (cores diferentes), permitindo o cálculo de suas respectivas taxas de aparecimento, mortalidade e sobrevivência da seguinte maneira:

1) Cálculo por touceira a cada época de amostragem:

Aparecimento: $\mathrm{n}^{\mathrm{o}}$ de perfilhos novos marcados x $100 / \mathrm{n}^{\circ}$ de dias do período $\mathrm{n}^{\mathrm{o}}$ total de perfilhos vivos na marcação anterior

Mortalidade: $\mathrm{n}^{\mathrm{o}}$ perfilhos mortos x $100 / n^{\circ}$ de dias do período $\mathrm{n}^{\mathrm{o}}$ total de perfilhos vivos na marcação anterior

Sobrevivência: $\mathrm{n}^{\mathrm{o}}$ perf da marcação anterior vivos na marcação atual $\times 100 / \mathrm{n}^{\circ}$ de dias do período $\mathrm{n}^{\mathrm{o}}$ total de perfilhos vivos na marcação anterior

2) Cálculo das taxas médias por unidade experimental (piquete):

As taxas de aparecimento, mortalidade e sobrevivência de cada touceira foram somadas e o total dividido por 4 (quatro touceiras/piquete), obtendo-se uma média para 
cada unidade experimental (piquete). Calculou-se as taxas médias mensais através de uma média ponderada do número de dias de cada mês pertencente a cada ciclo de pastejo. Essas taxas foram agrupadas por estação do ano, sendo o verão a média dos meses de janeiro a março, o outono de abril a junho, o inverno de julho a setembro, e a primavera de outubro a dezembro.

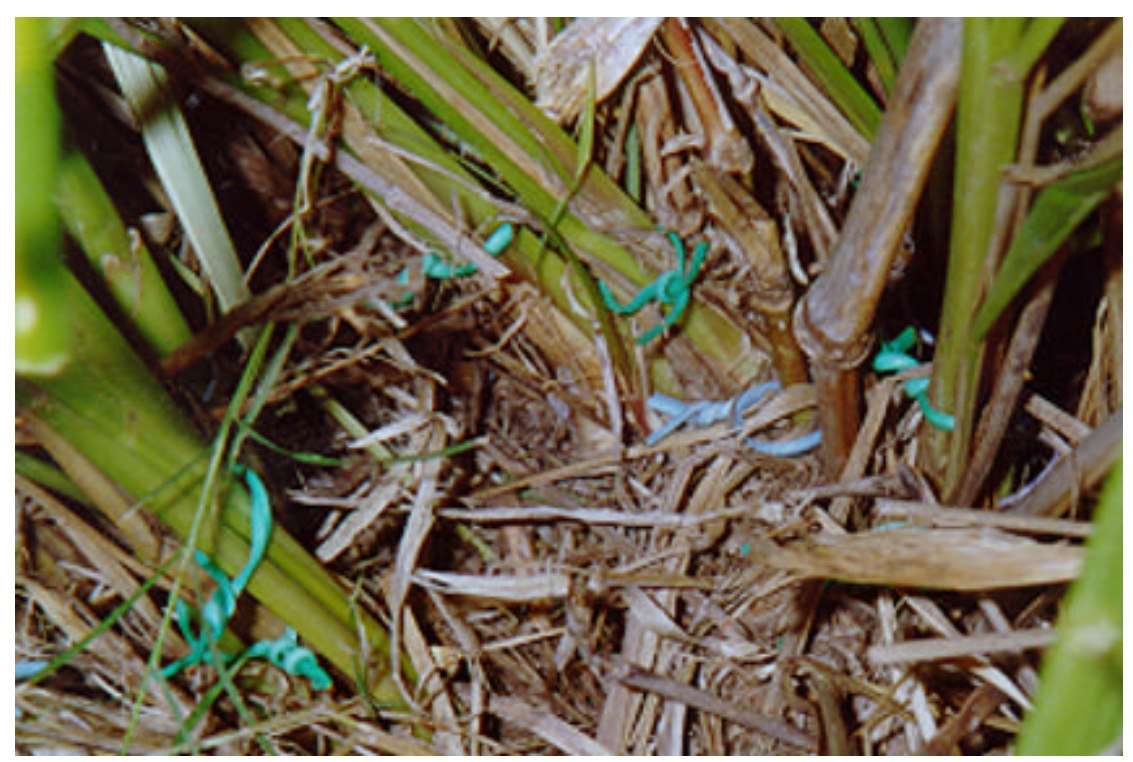

Figura 5 - Perfilhos marcados com arames revestidos de plástico colorido.

\subsubsection{Densidade populacional de perfilhos}

Os dados de densidade populacional de perfilhos foram obtidos através da contagem de perfilhos em 3 áreas de $1,0 \mathrm{~m}^{2}$ cada por unidade experimental (piquete), antes e depois do pastejo. A densidade populacional de cada unidade experimental foi obtida a partir da média das contagens nos 3 pontos de amostragem, sendo essas agrupadas por época do ano conforme a data da avaliação. As áreas de amostragem dentro de cada piquete foram mantidas fixas (mesmo local) durante o período de tempo em que essas permaneceram representativas da condição/estado médio do pasto. Quando 
isso não mais ocorria, as áreas de amostragem eram realocadas para novos pontos representativos do piquete.

\subsubsection{Altura do pasto}

A altura do pasto foi determinada utilizando-se uma régua de madeira de 2 metros de comprimento graduada em centímetros, com a qual foram medidos 16 pontos aleatórios por unidade experimental (Figura 6). A altura de cada ponto correspondeu à altura média do dossel em torno da régua, e a média dos 16 pontos correspondeu a altura média da unidade experimental (piquete).

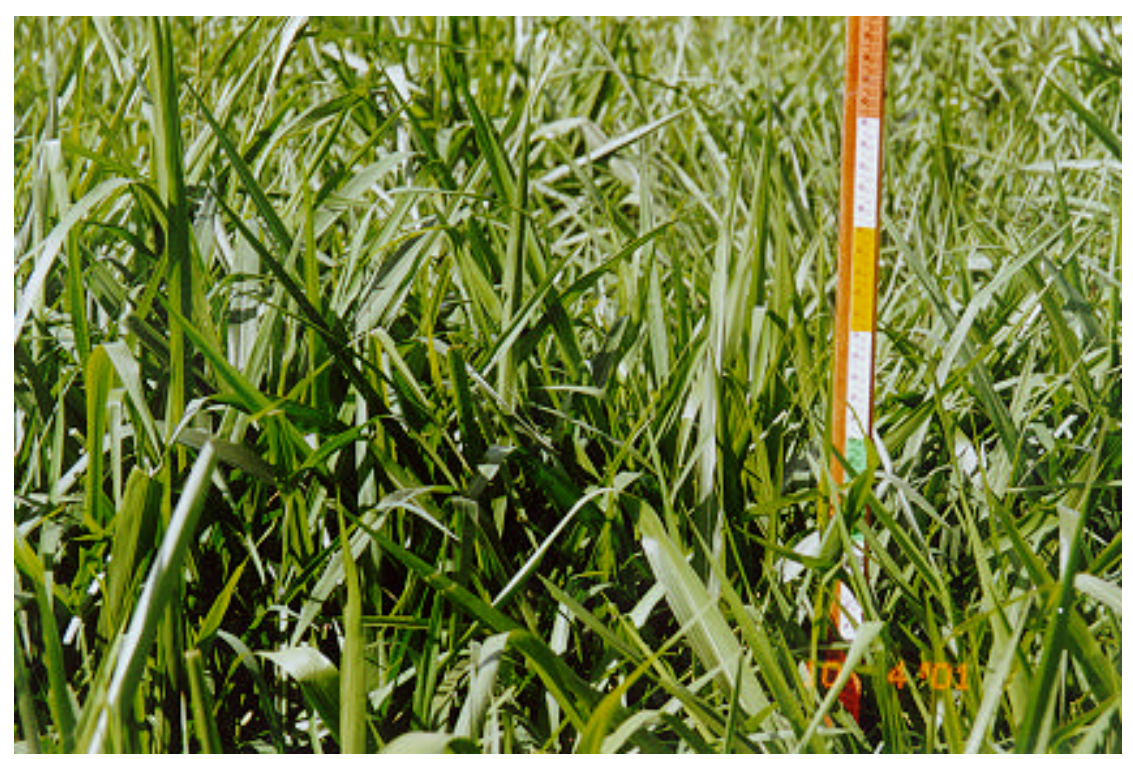

Figura 6 - Régua para a medição da altura dos piquetes.

\subsubsection{Massa de forragem}

A massa de forragem antes e depois do pastejo foi obtida através do uso de 3 quadrados de $1,0 \mathrm{~m}^{2}$ cada por unidade experimental, padronizando-se o corte da forragem a $20 \mathrm{~cm}$ de altura do solo a fim de não comprometer o estande do pasto (Figura 7). Esses quadrados foram posicionados em pontos que possuíam altura semelhante a 
altura média da unidade experimental, buscando-se pontos que fossem representativos da condição da pastagem. A amostra verde obtida foi pesada e sub-amostrada, e a subamostra seca em estufa a $65{ }^{\circ} \mathrm{C}$ para fins de conversão do peso verde da amostra em peso seco. A massa de forragem em cada unidade experimental foi calculada como sendo a média do peso seco das três amostras, valor esse convertido para kg MS.ha ${ }^{-1}$.

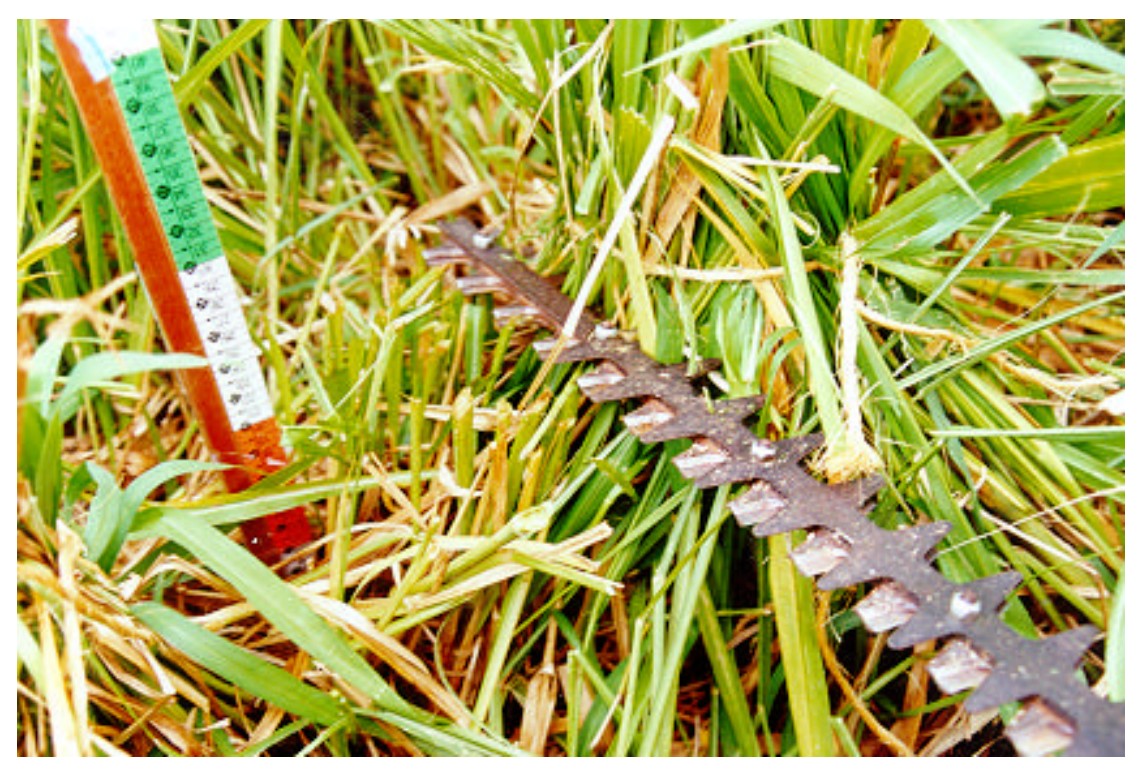

Figura 7 - Corte da massa de forragem no pré-pastejo.

\subsubsection{Taxas de acúmulo de forragem}

As taxas de acúmulo de forragem foram obtidas a partir da determinação da massa de forragem acumulada, calculada pela diferença entre a massa de forragem no pós-pastejo anterior e no pré-pastejo atual. Esse valor foi dividido pelo número de dias entre pastejos, gerando-se os valores de taxa de acúmulo para cada unidade experimental (piquete) (kg MS.ha ${ }^{-1} \cdot$ dia $^{-1}$ ) em cada período de avaliação (ciclo de pastejo). As médias mensais foram calculadas de forma ponderada a partir das taxas de cada ciclo de pastejo, de forma semelhante àquela descrita para padrões demográficos de perfilhamento (item 3.2.3). 
A produção total de massa seca durante o período experimental foi obtida como resultado da somatória das produções mensais de forragem, calculadas através da multiplicação das taxas de acúmulo mensais pelo número de dias de cada mês. 


\section{RESULTADOS E DISCUSSÃO}

Em função da natureza variável do intervalo entre desfolhas determinado pelas duas condições de início do pastejo (95 e 100\% IL), os dados foram agrupados por época do ano (primavera, verão, outono e inverno), exceção feita para as taxas de acúmulo de forragem, que foram calculadas mensalmente.

Os dados relativos a variáveis descritivas da condição dos pastos como altura e massa média de forragem dos piquetes no pré e no pós-pastejo e intervalos entre pastejos são apresentados apenas através de médias, sem análise estatística. Já aqueles relativos a taxas e processos como demografia do perfilhamento, densidade populacional de perfilhos no pré e no pós-pastejo, taxas de acúmulo de forragem e acúmulo total de massa seca no período experimental foram submetidos a análise de variância e os resultados apresentados de forma tradicional.

\subsection{Intervalo médio entre pastejos}

Os intervalos médios entre pastejos são apresentados na Tabela 3. Observa-se que para a média da estação de crescimento o principal determinante do intervalo entre pastejos foi o nível de interceptação luminosa para o início do pastejo, independentemente do resíduo. No caso de pastejos iniciados com 100\% IL, o tratamento de resíduo $50 \mathrm{~cm}$ apresentou um intervalo entre pastejos mais curto que o de $30 \mathrm{~cm}$ (33 vs 39 dias). Outra característica interessante é a forte estacionalidade existente entre as épocas de primavera/verão e outono/inverno, resultando em períodos de descanso 4,1; 2,9; 5,8 e 5,6 vezes mais longos durante o outono/inverno para os tratamentos 30/95, 30/100, 50/95 e 50/100, respectivamente. Na média da estação de 
crescimento (primavera/verão) houve uma diferença de 9 a 16 dias entre os tratamentos de 95 e 100\% IL para os resíduos de 50 e $30 \mathrm{~cm}$, respectivamente, indicando que apesar de pequena, a diferença entre as metas de interceptação luminosa para início do pastejo (5\%), resultou em aumento considerável no intervalo entre pastejos em condições de campo (53\%). No período de outono-inverno a diferença foi de 20 e 46 dias entre os tratamentos de 95 e 100\% IL para os resíduos de 30 e $50 \mathrm{~cm}$, respectivamente, um aumento de $27 \%$ no período de descanso.

Tabela 3. Intervalo médio entre pastejos (dias) durante o período experimental.

\begin{tabular}{cccc}
\hline Tratamento* & \multicolumn{2}{c}{ Média de intervalo entre pastejos } \\
Época & Média da época & $\begin{array}{c}\text { Média da estação de } \\
\text { crescimento** }\end{array}$ \\
\hline $30 / 95$ & primavera & 22 & 23 \\
& verão & 24 & \\
\multirow{3}{*}{$30 / 100$} & outono/inverno & 95 & 39 \\
& primavera & 40 & \\
& verão & 37 & 24 \\
$50 / 95$ & outono/inverno & 115 & \\
& primavera & 23 & 33 \\
& verão & 25 & \\
$50 / 100$ & outono/inverno & 140 & \\
& primavera & 35 & \\
& verão & 31 & \\
& outono/inverno & 186 & \\
\hline
\end{tabular}

*Tratamento = resíduo $(\mathrm{cm}) /$ interceptação de luz $(\%)$.

**Primavera/verão.

Durante a primavera/verão, época de crescimento vegetativo das plantas, os pastos com resíduo de $50 \mathrm{~cm}$ se recuperaram mais rápido, resultando no menor período de descanso em relação àqueles de resíduo $30 \mathrm{~cm}$. No entanto, durante o período de outono/inverno, época de crescimento reprodutivo e florescimento das plantas, o comportamento foi inverso, com os pastos de resíduo $50 \mathrm{~cm}$ demorando mais para se recuperar que pastos de resíduo $30 \mathrm{~cm}$, provavelmente consequência da maior proporção e intensidade de florescimento naquelas condições. Pastos manejados com resíduo de 50 $\mathrm{cm}$ apresentaram florescimento mais intenso que os de resíduo $30 \mathrm{~cm}$, assim como os de $100 \%$ em relação aos de $95 \%$ IL (Figuras 8 e 9). 


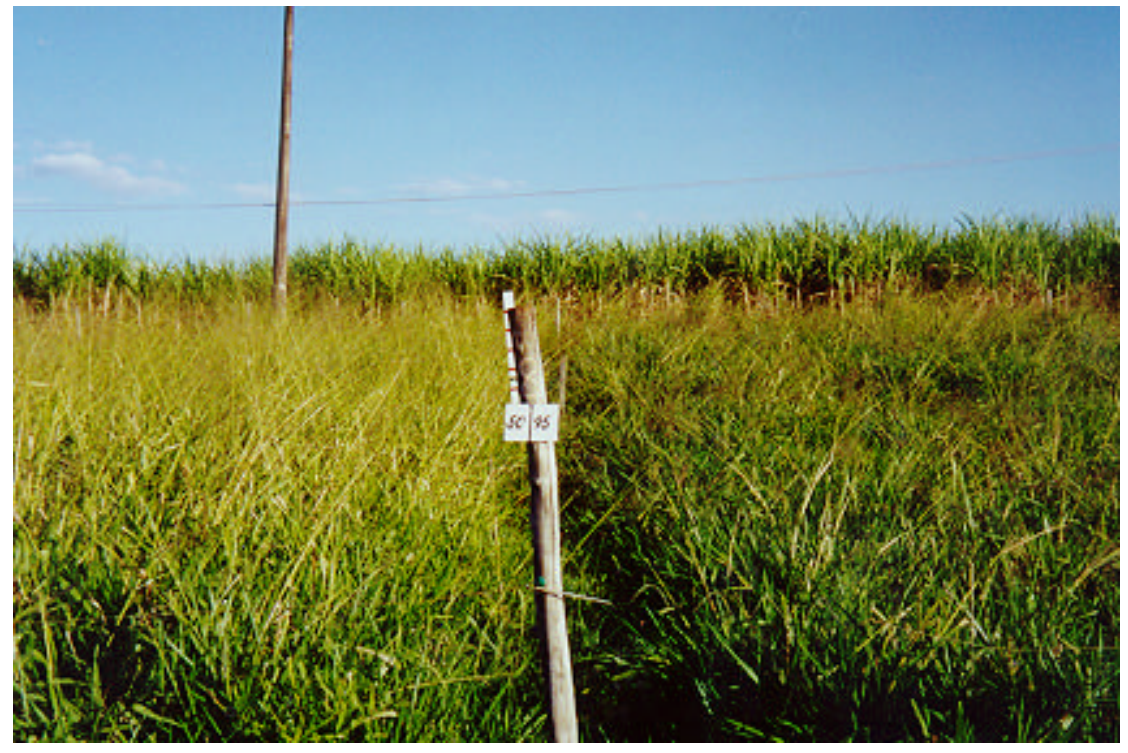

Figura 8 - Florescimento nos pastos correspondentes ao tratamento 30/100 (esquerda) e 50/95 (direita).

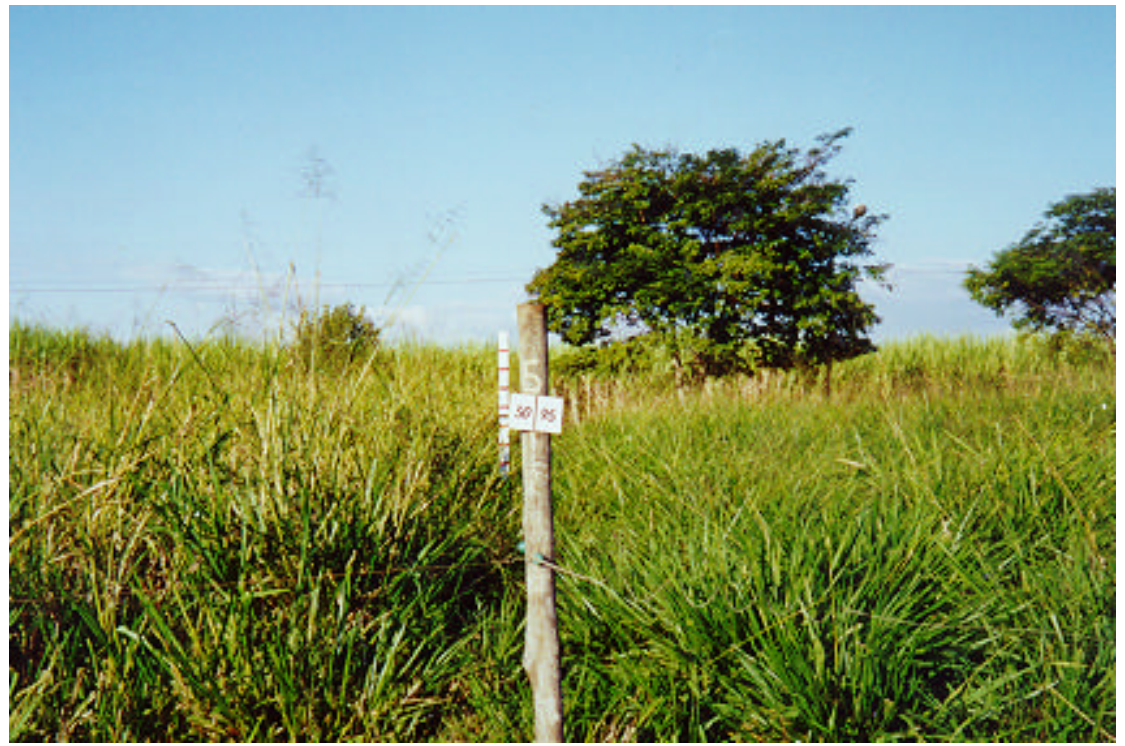

Figura 9 - Florescimento nos pastos correspondentes ao tratamento 50/100 (esquerda) e 30/95 (direita). 
A implicação prática dos resultados é simples, períodos de descanso fixos de manejo do pastejo são potencialmente perigosos, e seus efeitos dependentes do estádio de desenvolvimento das plantas, podendo resultar em perdas significativas em produção e qualidade da forragem.

O período de descanso mais longo pode ter consequências sobre a estrutura do pasto e o valor nutritivo da forragem produzida, uma vez que pode propiciar um maior acúmulo relativo de hastes e material morto na massa de forragem existente, além de tecido vegetal de idade mais avançada. Nelson \& Moser (1994) e Buxton \& Fales (1994) apontaram a maturidade como o fator mais determinante da morfologia da planta e da qualidade da forragem. Segundo Nelson \& Moser (1994), o conteúdo de parede celular de folhas aumenta apenas cerca de $10 \%$ com a maturidade e, por isso, o declínio na qualidade da forragem é atribuído ao decréscimo da relação folha:haste e ao declínio da qualidade da haste.

Santos (2002) observou queda da digestibilidade "in vitro" da matéria orgânica das gerações mais velhas de perfilhos (3 a 6 pontos percentuais de digestibilidade por ciclo de 33 dias de crescimento). Pinto et al. (1994), em estudo com capim-Guiné (Panicum maximum cv. Guiné), observaram diminuição da relação folha:haste a medida que a idade de rebrota aumentava, sendo que com 14, 28, 42, 56 e 70 dias encontraram relação folha:haste de 1,$3 ; 1,2 ; 1,0 ; 0,7$ e 0,5 , respectivamente. $\mathrm{O}$ mesmo tipo de comportamento foi determinado por Andrade (1987) avaliando o capimTobiatã (Panicum maximum cv Tobiatã), e Santos (1997) avaliando os capins Mombaça e Tanzânia (Panicum maximum cv Tanzânia).

\subsection{Altura média do pasto}

\subsubsection{Pré-pastejo}

A altura média no pré-pastejo foi bastante consistente para cada tratamento durante todo o período experimental (Tabela 4), revelando que essa medida constitui um bom indicador da condição de interceptação luminosa do pasto. Assim, a interceptação de $95 \%$ da luz incidente ocorreu em torno de $90 \mathrm{~cm}(85$ a $95 \mathrm{~cm}$ ) (Figura 10) e de 100\% 
em torno de $115 \mathrm{~cm}(115$ a $120 \mathrm{~cm})$ de altura. Esse resultado aponta de forma bastante promissora para o uso da altura do pasto em pré-pastejo como um parâmetro-guia confiável para controle e manejo do pastejo em situações de desfolha intermitente, como por exemplo o pastejo rotacionado, desde que seus valores tenham sido obtidos a partir de medidas de IAF e IL correspondentes.

Assim como para o intervalo entre pastejos, o maior efeito observado foi da condição caracterizada pelo início do pastejo aos 95 ou $100 \%$ IL (23\%) relativamente aos resíduos de 30 e $50 \mathrm{~cm}(5,5 \%)$.

Tabela 4. Altura média $(\mathrm{cm})$ dos pastos em pré-pastejo durante o período experimental.

\begin{tabular}{cccc}
\hline \multirow{3}{*}{ Tratamento* } & \multicolumn{2}{c}{ Altura média } & \\
& Época & Média da época & Média do tratamento \\
\hline \multirow{3}{*}{$30 / 95$} & primavera & 92 & 86 \\
& verão & 83 & \\
& outono/inverno & 84 & \multirow{2}{*}{114} \\
$50 / 100$ & primavera & 120 & \\
& verão & 117 & 93 \\
& outono/inverno & 105 & \\
$50 / 100$ & primavera & 93 & 118 \\
& verão & 92 & \\
& outono/inverno & 93 & \\
& primavera & 119 & \\
& verão & 114 & \\
& outono/inverno & 122 & \\
\hline
\end{tabular}

*Tratamento $=$ resíduo $(\mathrm{cm}) /$ interceptação de luz $(\%)$. 


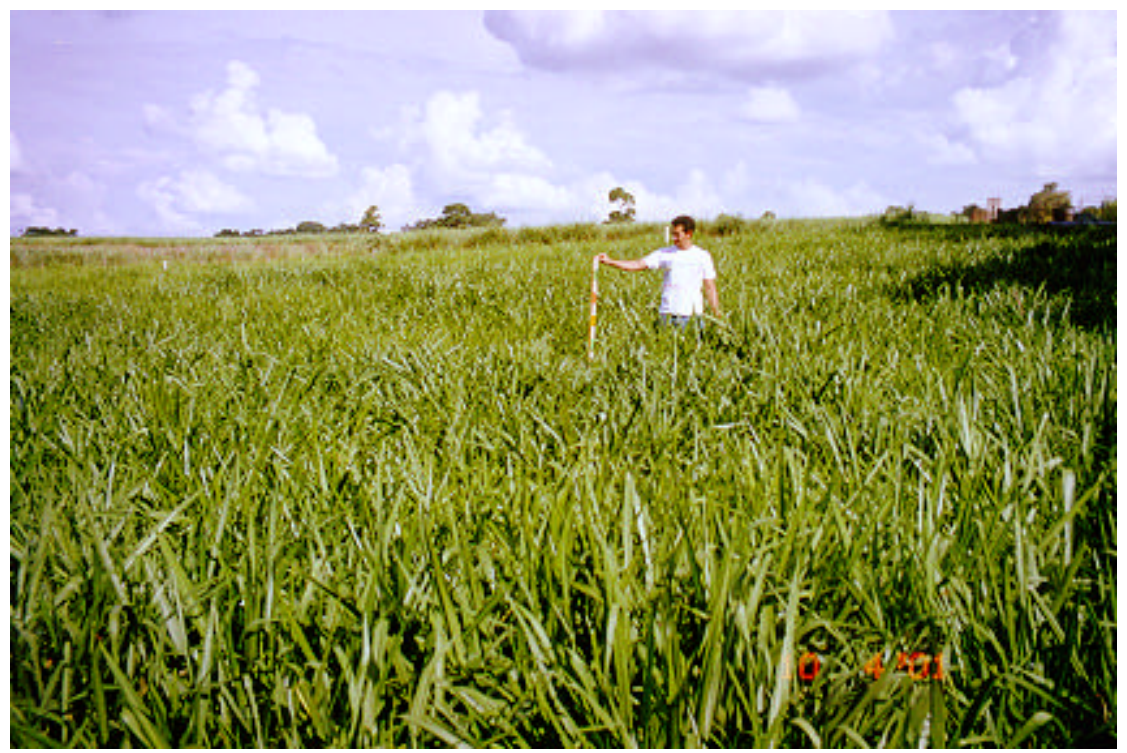

Figura 10 - Altura em pré-pastejo dos pastos com início da desfolha a 95\% IL (90 cm de altura).

\subsubsection{Pós-pastejo}

Não houve dificuldades em se manter a altura do resíduo dos tratamentos de $50 \mathrm{~cm}$ (Figura 11), independentemente da interceptação luminosa, sendo que esse variou de 50 a $54 \mathrm{~cm}$ para $95 \%$ e 100\% IL, respectivamente (Tabela 5). Comportamento semelhante ocorreu para o tratamento de resíduo de $30 \mathrm{~cm}$ quando combinado a pastejos iniciados com 95\% IL, com a altura média ficando em torno de $33 \mathrm{~cm}$ (Figura 12). Não foi possível manter o resíduo para o tratamento de resíduo $30 \mathrm{~cm}$ com $100 \%$ de interceptação luminosa, cuja altura pós-pastejo ficou em torno de $42 \mathrm{~cm}(41 \mathrm{a} 44 \mathrm{~cm})$ (Figura 13). 
Tabela 5. Altura média $(\mathrm{cm})$ dos pastos em pós-pastejo durante o período experimental.

\begin{tabular}{|c|c|c|c|}
\hline \multicolumn{4}{|c|}{ Altura média } \\
\hline Tratamento & Época & Média da época & Média do tratamento \\
\hline \multirow[t]{3}{*}{$30 / 95$} & primavera & 33 & \\
\hline & verão & 32 & 33 \\
\hline & outono/inverno & 35 & \\
\hline \multirow[t]{3}{*}{$30 / 100$} & primavera & 44 & \\
\hline & verão & 41 & 42 \\
\hline & outono/inverno & 42 & \\
\hline \multirow[t]{3}{*}{$50 / 95$} & primavera & 51 & \\
\hline & verão & 50 & 50 \\
\hline & outono/inverno & 50 & \\
\hline \multirow[t]{3}{*}{$50 / 100$} & primavera & 55 & \\
\hline & verão & 53 & 54 \\
\hline & outono/inverno & 54 & \\
\hline
\end{tabular}

*Tratamento = resíduo $(\mathrm{cm}) /$ interceptação de luz $(\%)$.

Não houve aumento da altura do resíduo na época de florescimento (outono e inverno) em relação as demais épocas do ano (crescimento vegetativo), indicando que a grande dificuldade no controle de hastes deve estar mais relacionada ao controle da frequência de pastejos e que, independentemente da época do ano ou do estádio fenológico da planta (florescimento), o resíduo inicial pode ser mantido se combinado a frequências de pastejo e/ou corte adequadas.

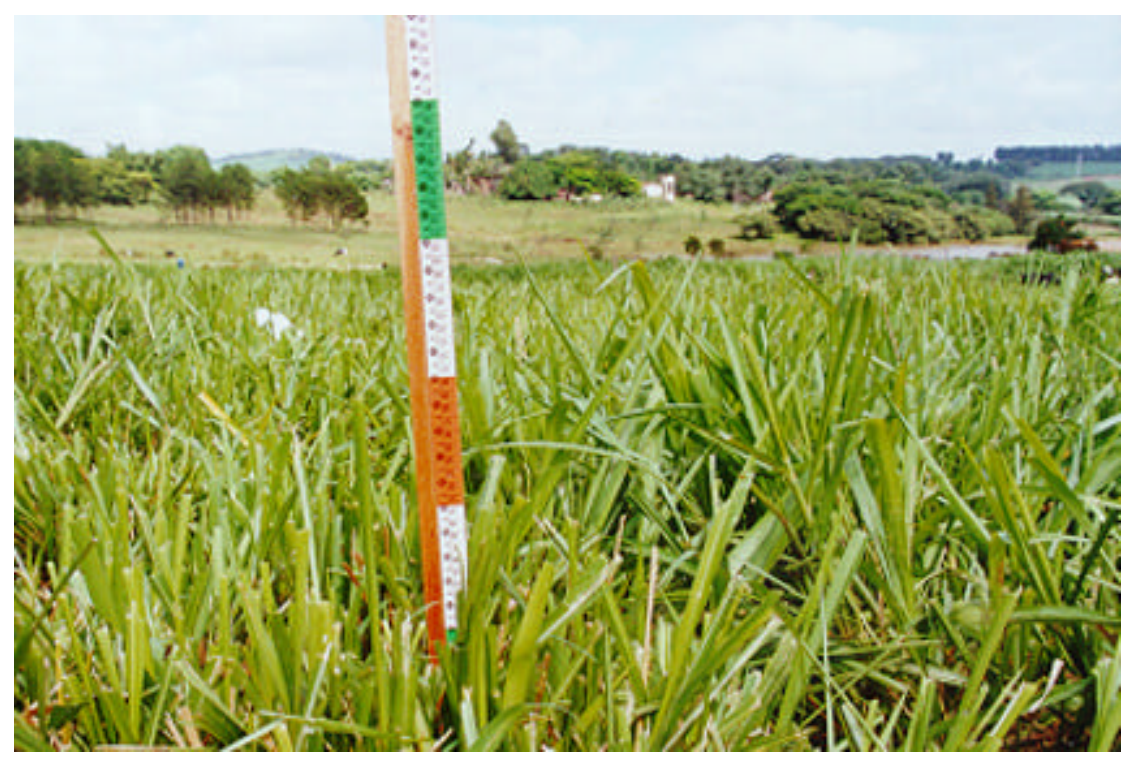

Figura 11 - Resíduo pós-pastejo dos pastos manejados com um resíduo de 50 cm. 


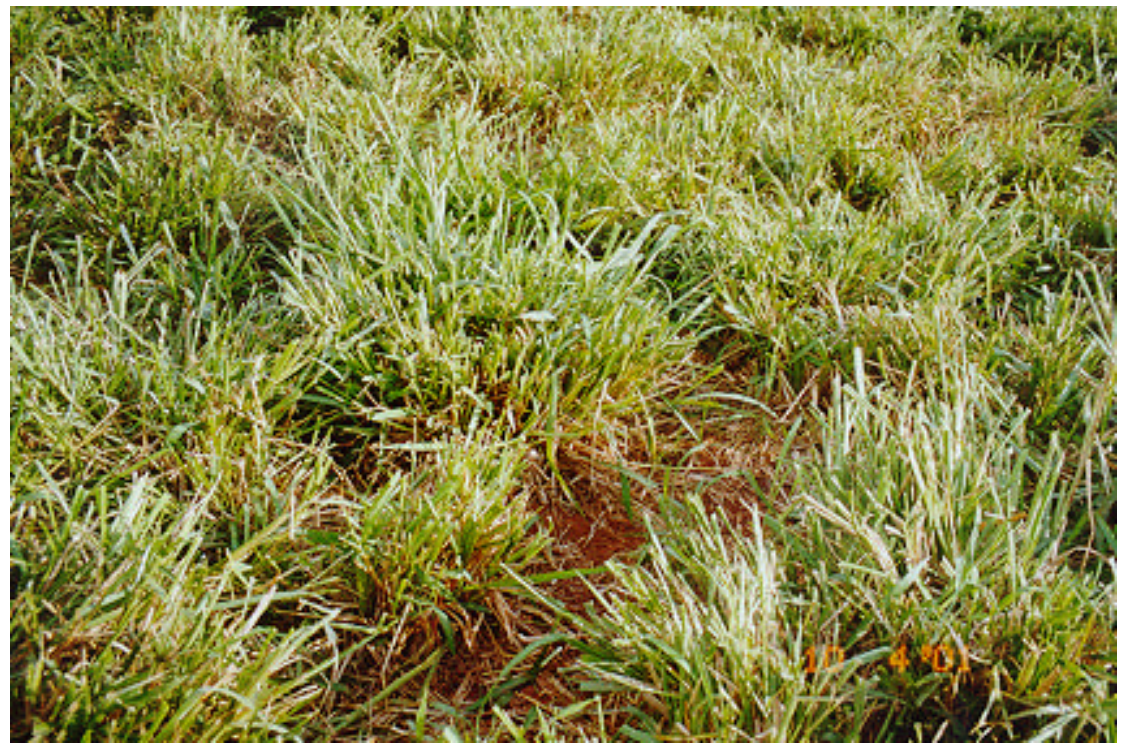

Figura 12- Resíduo pós-pastejo dos pastos manejados conforme o tratamento 30/95.

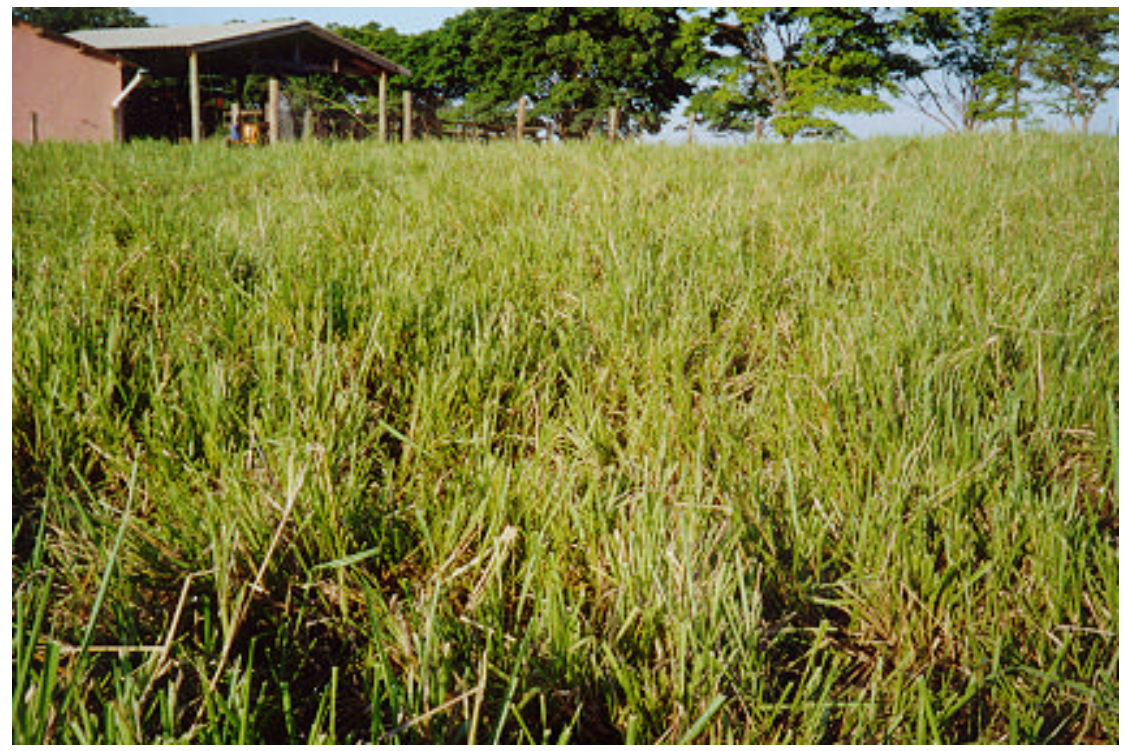

Figura 13 - Resíduo pós-pastejo dos pastos manejados conforme o tratamento 30/100. 


\subsection{Massa de forragem do pasto}

\subsubsection{Pré-pastejo}

A maior massa de forragem em pré-pastejo ocorreu para os tratamentos que tiveram o pastejo iniciado com 100\% IL (Tabela 6), pois estes permitiram um período de crescimento mais longo e, provavelmente, maior acúmulo de hastes e material morto (Pinto et al.,1994, Andrade, 1987 e Santos, 1997). Para esses tratamentos foi observada uma massa de forragem maior no período outono/inverno, provavelmente resultado do maior desenvolvimento reprodutivo e alongamento de hastes de perfilhos induzidos ao florescimento. Essa diferença em massa de forragem entre as épocas do ano não ocorreu nos tratamentos com pastejos iniciados com 95\% IL, indicando que esses apresentaram pouco desenvolvimento reprodutivo (Figuras 8 e 9).

Braga (2001) avaliou a morfologia do pasto de capim-Mombaça submetido a dois intervalos entre cortes (28 e 42 dias) e obteve maior número de perfilhos em desenvolvimento reprodutivo (fase de alongamento de hastes e florescimento) nos tratamentos com 42 dias de intervalo entre cortes, sendo que esses perfilhos exerceram forte influência na produção de massa seca. Santos (1997), em experimento com os capins Mombaça e Tanzânia, observou maior florescimento para pastejos realizados a cada 48 dias em relação àqueles realizados a cada 28 ou 38 dias. 
Tabela 6. Massa de forragem média (kg.ha ${ }^{-1}$ de MS) em pré-pastejo.

\begin{tabular}{cccc}
\hline \multirow{3}{*}{ Tratamento* } & \multicolumn{2}{c}{ Massa de forragem } & \\
& Época & Média da época & Média do tratamento \\
\hline \multirow{3}{*}{$30 / 95$} & primavera & 4.530 & 4.690 \\
& verão & 4.820 & \\
& outono/inverno & 4.720 & 7.920 \\
primavera & 7.880 & \\
$50 / 100$ & verão & 7.820 & 6.120 \\
& outono/inverno & 8.050 & \\
& primavera & 5.730 & \\
& verão & 6.480 & 8.250 \\
& outono/inverno & 6.150 & \\
& primavera & 8.200 & \\
& verão & 7.630 & \\
& outono/inverno & 8.910 & \\
\hline
\end{tabular}

*Tratamento = resíduo $(\mathrm{cm}) /$ interceptação de luz (\%).

A massa de forragem em pré-pastejo foi menor para os tratamentos de resíduo de $30 \mathrm{~cm}$, independentemente da interceptação luminosa. Considerando-se que os cortes foram padronizados a $20 \mathrm{~cm}$ do nível do solo, esse resultado reflete o maior acúmulo de hastes e material morto no resíduo de $50 \mathrm{~cm}$, já que a altura em pré-pastejo não foi muito diferente entre os tratamentos de mesma interceptação luminosa (Tabela 4).

\subsubsection{Pós-pastejo}

Foi constatada uma menor massa de forragem em pós-pastejo para os tratamentos de $30 \mathrm{~cm}$ de resíduo, revelando que essa intensidade de pastejo propiciou remoção de uma maior proporção da forragem existente no pré-pastejo, que ficou em $63,7 \%$ para o tratamento 30/95 e 56,9\% para o 30/100. Para os tratamentos de resíduo 50 cm, essa remoção foi bem menor devido à grande massa de forragem que não era colhida (Tabela 7) (Figura 11), variando de 33,2\% a 39,3\% para os tratamentos 50/95 e 50/100, respectivamente. 
Tabela 7. Massa de forragem média (kg.ha $\left.{ }^{-1} \mathrm{de} \mathrm{MS}\right)$ em pós-pastejo.

\begin{tabular}{cccc}
\hline \multirow{2}{*}{ Tratamento* } & \multicolumn{2}{c}{ Massa de forragem } & \\
& Época & Média da época & Média do tratamento \\
\hline $30 / 95$ & primavera & 1.810 & 1.700 \\
& verão & 1.520 & \\
\multirow{3}{*}{$30 / 100$} & outono/inverno & 1.730 & 3.410 \\
& primavera & 3.650 & \\
& verão & 3.270 & 4.090 \\
$50 / 95$ & outono/inverno & 3.330 & \\
& primavera & 4.510 & \multirow{2}{*}{5.010} \\
& verão & 3.890 & \\
& outono/inverno & 3.880 & \\
& primavera & 5.084 & \\
& verão & 4.390 & \\
& outono/inverno & 5.340 & \\
\end{tabular}

*Tratamento $=$ resíduo $(\mathrm{cm}) /$ interceptação de luz $(\%)$.

\subsection{Demografia do perfilhamento}

As Figuras 14, 15, 16 e 17 ilustram a dinâmica populacional de perfilhos para cada unidade experimental (piquete) a partir das médias originais dos dados (calculadas com base nas datas de ocorrência dos pastejos) com o intuito apenas de visualizar o comportamento geral da demografia de perfilhos. Eventuais diferenças entre gráficos do mesmo tratamento (blocos 1 a 4) podem refletir um efeito de época de pastejo, uma vez que piquetes do mesmo tratamento foram pastejados em datas diferentes ao longo do período experimental (Tabela 2). 
(a)

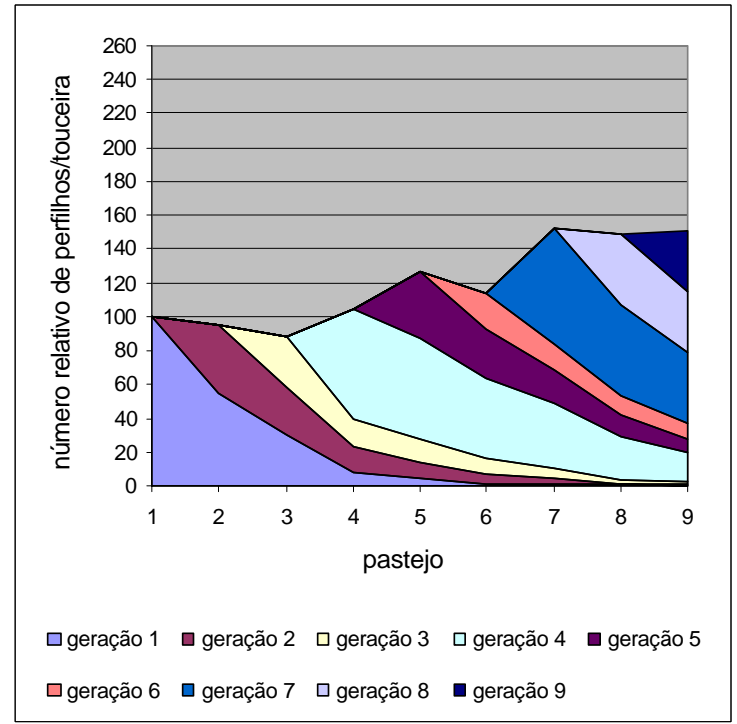

(c)

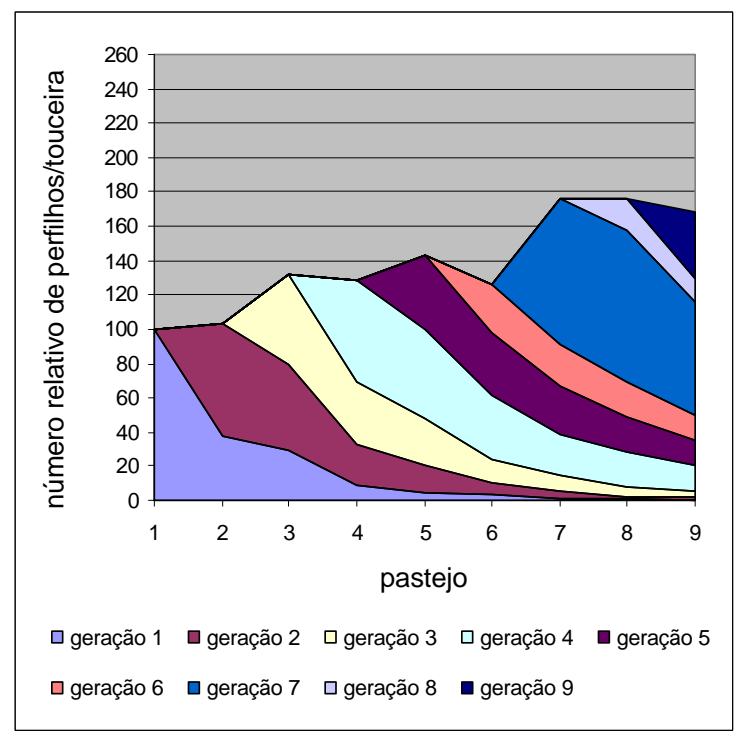

(b)

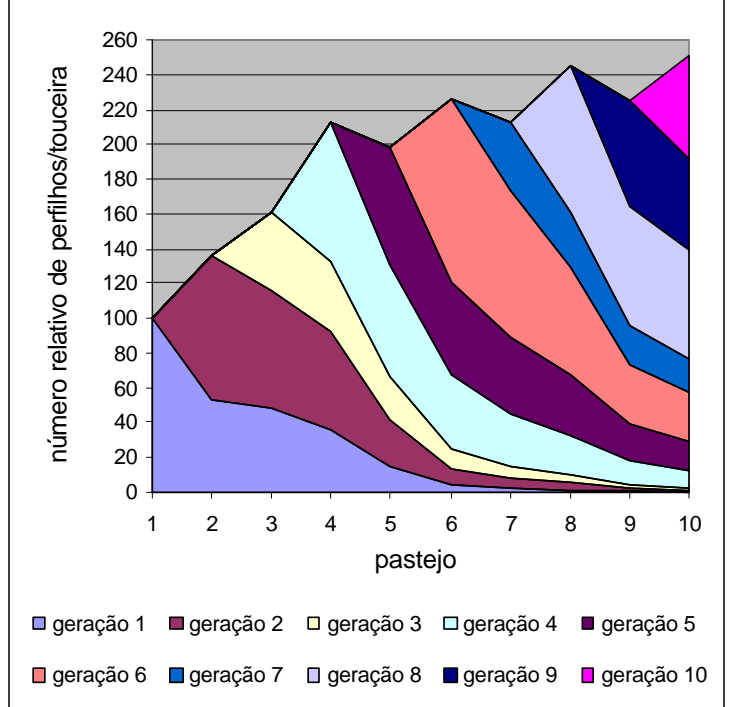

(d)

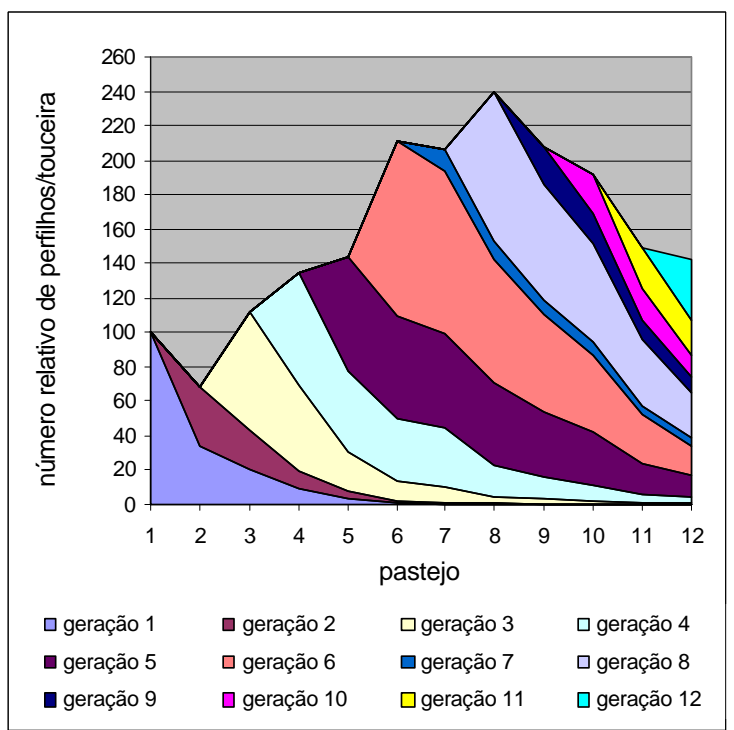

Figura 14 - Dinâmica populacional de perfilhos para cada unidade experimental (piquete) do tratamento 30/95: (a) bloco 1, (b) bloco 2, (c) bloco 3, (d) bloco 4. 
(a)

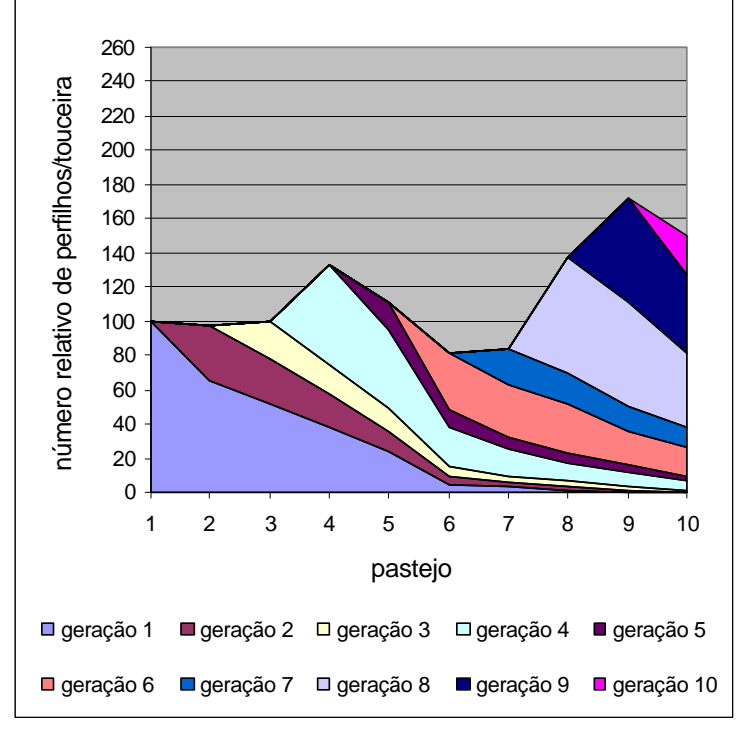

(c)

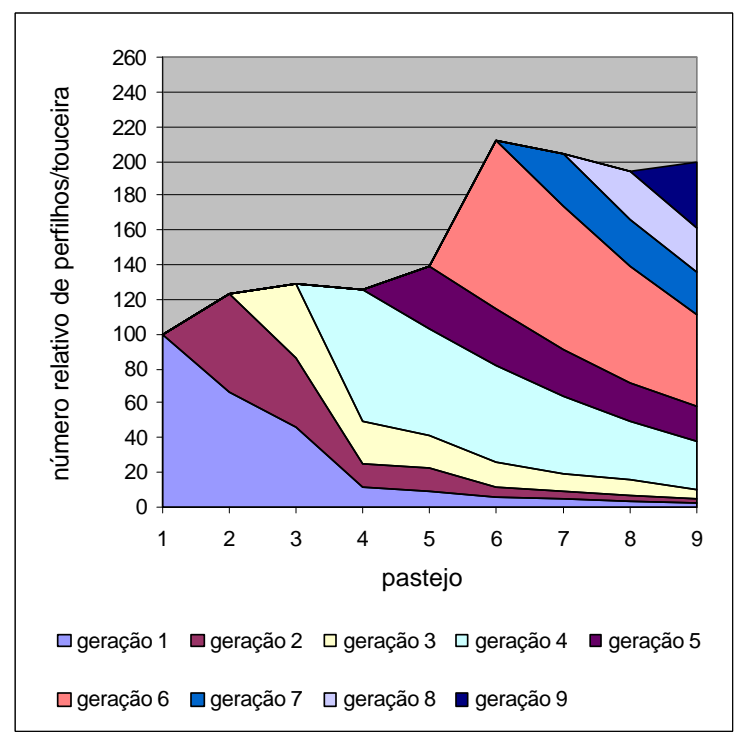

(b)

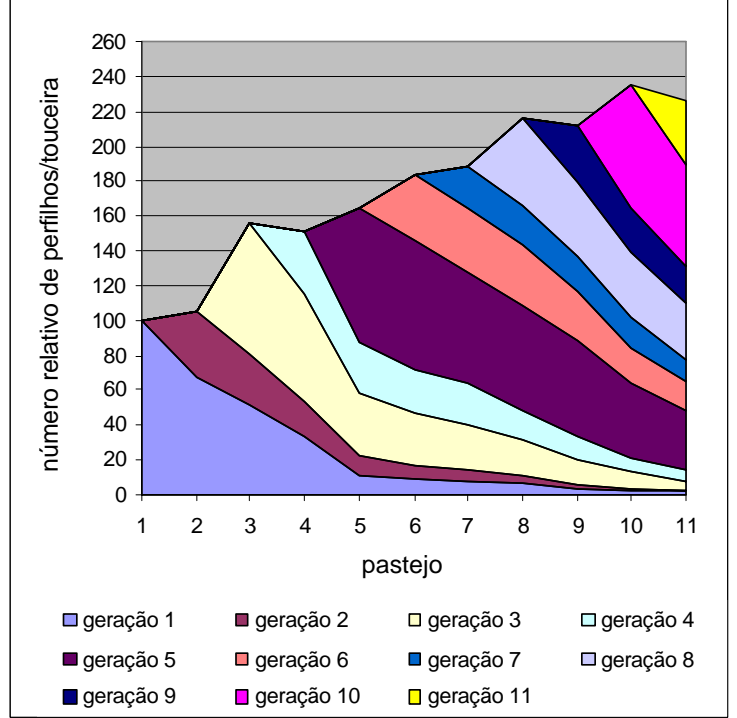

(d)

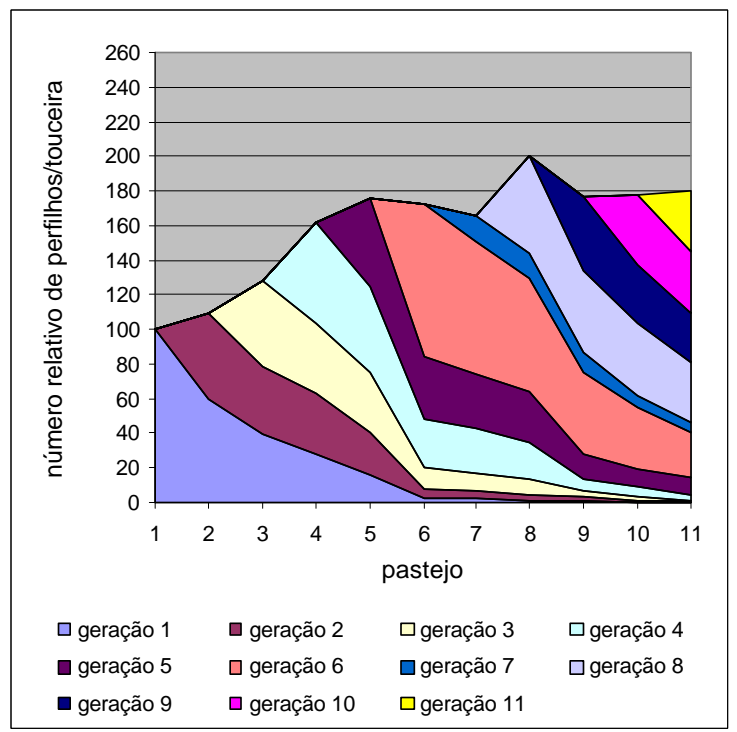

Figura 15 - Dinâmica populacional de perfilhos para cada unidade experimental (piquete) do tratamento 50/95: (a) bloco 1, (b) bloco 2, (c) bloco 3, (d) bloco 4. 
(a)

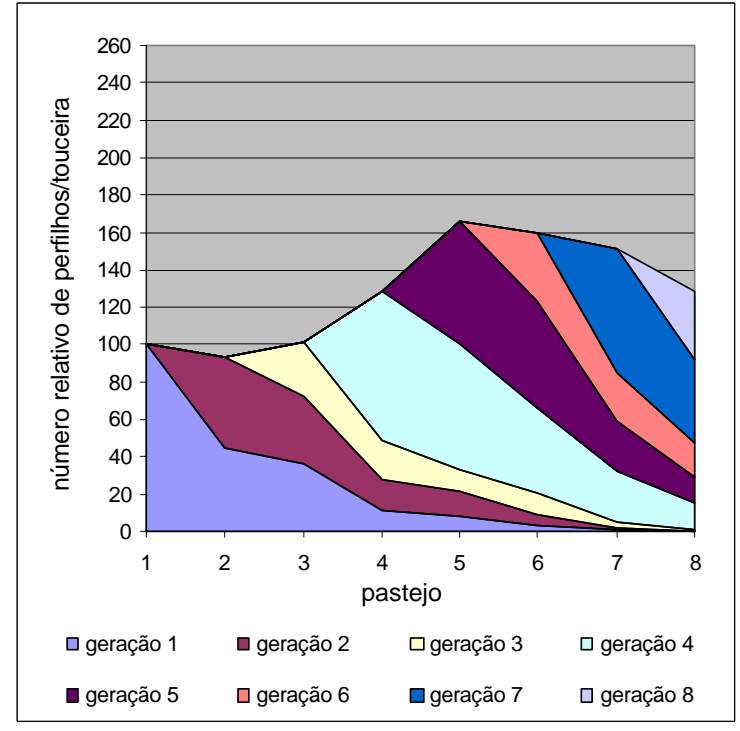

(c)

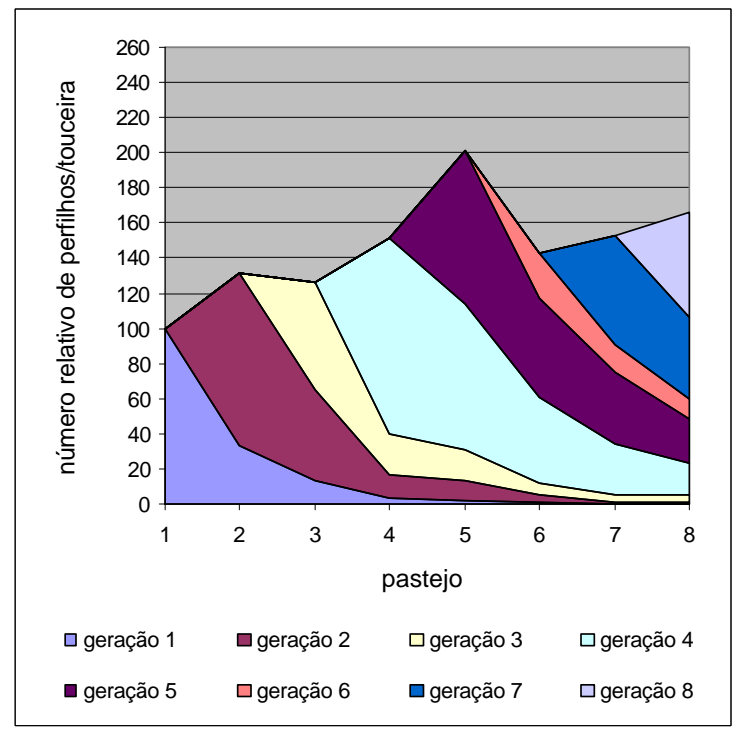

(b)

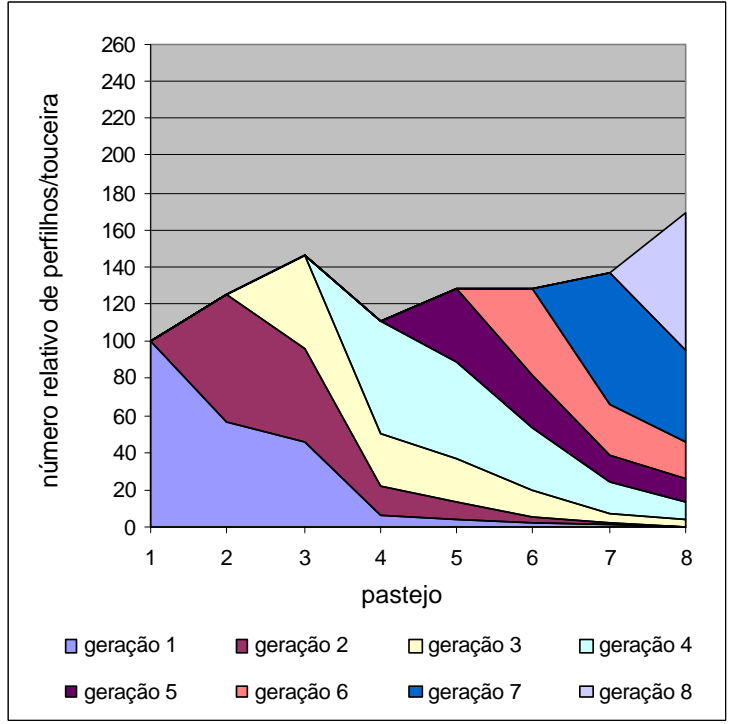

(d)

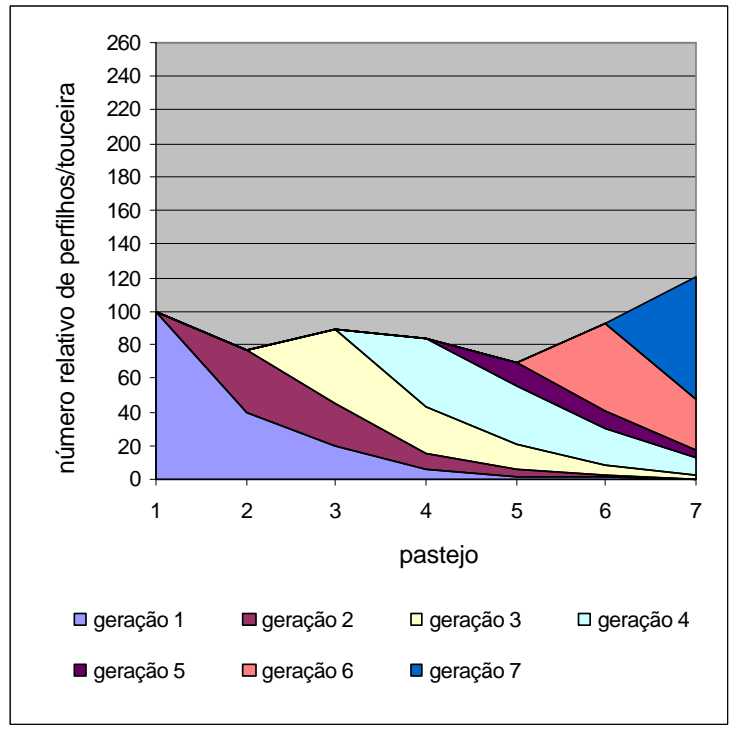

Figura 16 - Dinâmica populacional de perfilhos para cada unidade experimental (piquete) do tratamento 30/100: (a) bloco 1, (b) bloco 2, (c) bloco 3, (d) bloco 4. 
(a)

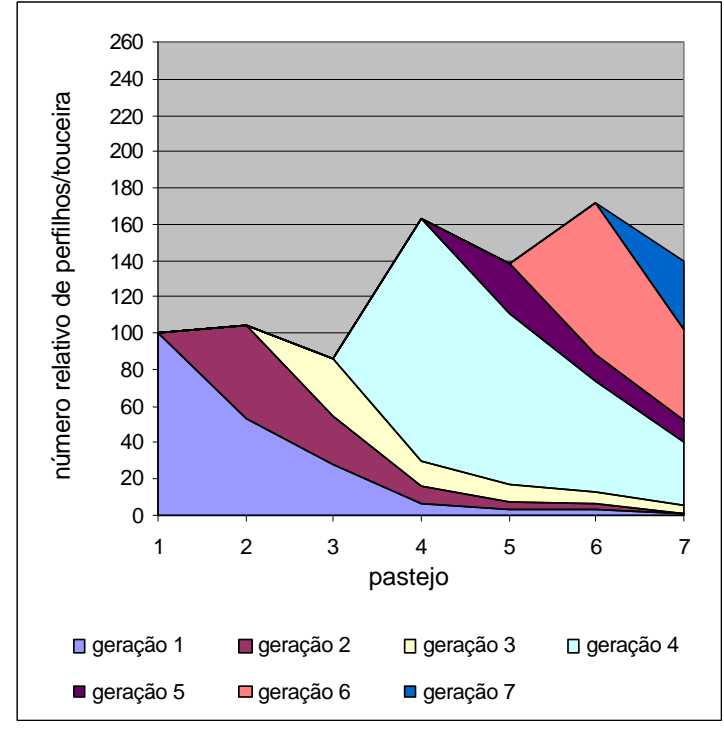

(c)

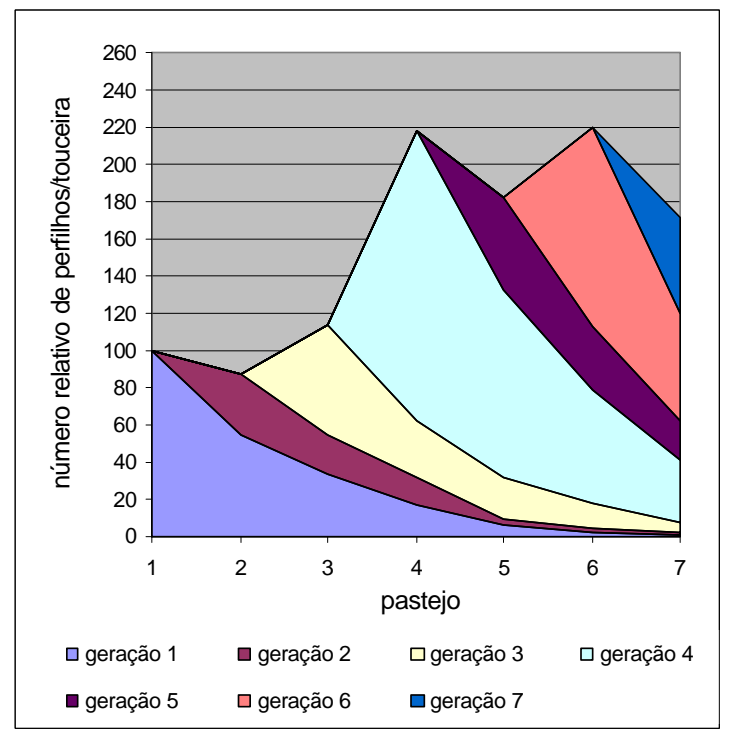

(b)

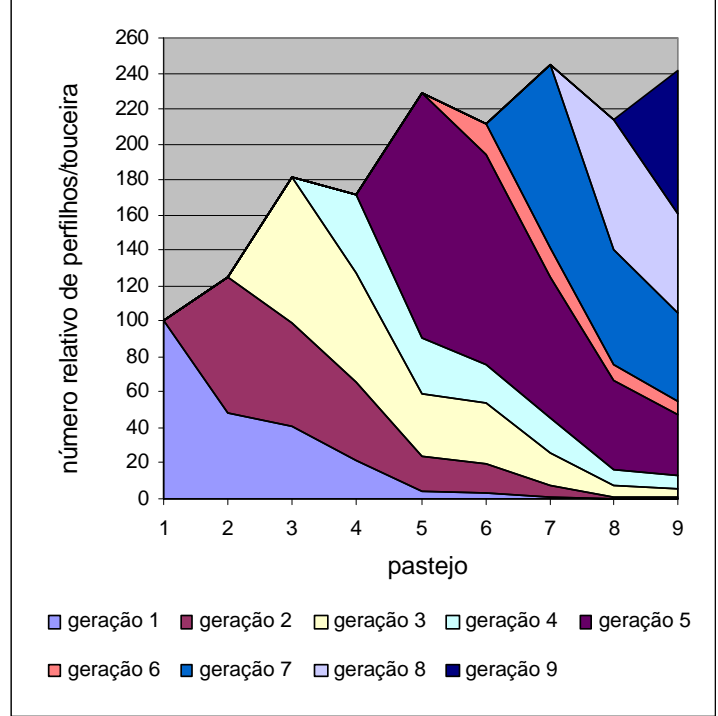

(d)

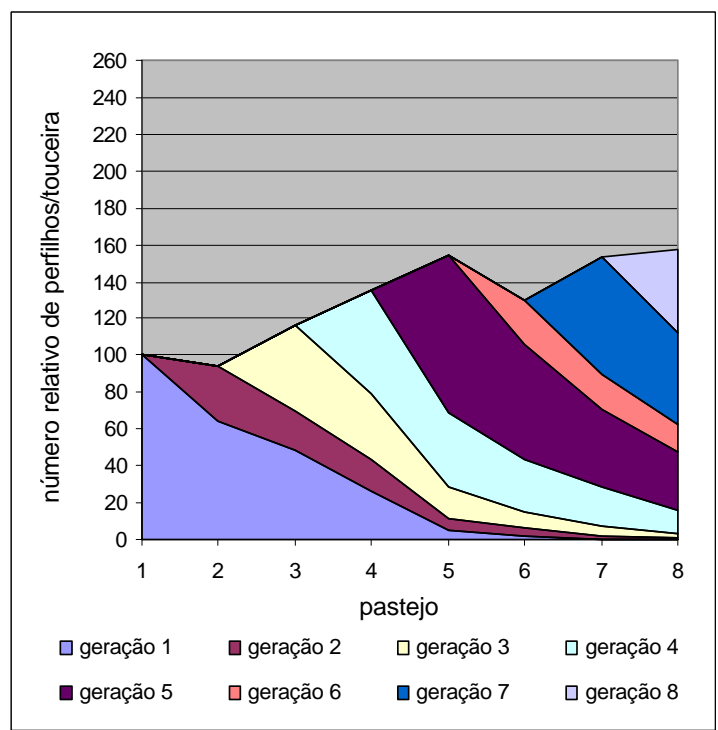

Figura 17 - Dinâmica populacional de perfilhos para cada unidade experimental (piquete) do tratamento 50/100: (a) bloco 1, (b) bloco 2, (c) bloco 3, (d) bloco 4. 
Existiu um efeito claro da frequência de desfolha de forma que pastejos realizados com $95 \%$ de IL favoreceram uma dinâmica populacional e uma renovação mais rápida da população de perfilhos existentes que pastejos realizados com $100 \%$ IL. $\mathrm{O}$ efeito de intensidade de desfolha foi menos evidente, porém, quando a altura de $30 \mathrm{~cm}$ de resíduo foi associada ao pastejo com $100 \%$ de IL houve queda sensível no número de perfilhos relativamente ao resíduo de $50 \mathrm{~cm}$ (especialmente para os blocos 2 e 4), indicando que períodos longos de rebrotamento podem ser prejudiciais caso sejam associados a desfolhas drásticas quando a área foliar remanescente é pequena e de baixa eficiência fotossintética. Esse tipo de situação é típico de áreas manejadas intensivamente através de irrigação, elevados níveis de fertilização nitrogenada e colheita mecânica, em que o custo fixo de produção é elevado e, portanto, necessita da maior produção possível por evento de corte ou pastejo. Nesse caso, os benefícios potenciais dos insumos e tecnologia empregados no processo de intensificação da produção correm o risco de não serem realizados e as expectativas de técnicos e fazendeiros frustradas.

\subsubsection{Taxas de aparecimento}

Foi observada interação entre resíduo, interceptação luminosa e época do ano $(\mathrm{P}=0,0886)$ para as taxas de aparecimento de perfilhos. Não houve diferença entre os resíduos de 30 e $50 \mathrm{~cm}(\mathrm{P}=0,6812)$, exceto na primavera, quando o resíduo de $50 \mathrm{~cm}$ apresentou uma taxa de aparecimento maior que o de $30 \mathrm{~cm}$ (Tabela 8). Os dados corroboram aqueles obtidos por Coelho et al. (1999) em estudo com os capins Colonião, Mombaça, Tanzânia e Tobiatã, que não observaram efeito da altura de corte (20 e 40 cm) sobre o aparecimento de perfilhos. L’Huillier (1987) e Carvalho (2000) também não obtiveram diferenças entre as intensidades de pastejo testadas em pastos de azevém perene e Cynodon spp., respectivamente. A atividade de perfilhamento está relacionada a mudanças em temperatura (Mitchell, 1953; Gillet et al, 1984) e regimes de luz, sendo controlada pela taxa de aparecimento de folhas (Davies \& Thomas, 1983) que, por sua vez, é insensível à desfolha (Anslow, 1966). Esse fato pode explicar porque não foram 
detectadas diferenças entre o aparecimento de perfilhos e a intensidade de desfolha dos tratamentos. No presente experimento, o menor resíduo utilizado $(30 \mathrm{~cm})$ não foi planejado para ser drástico o suficiente de forma a interferir negativamente no perfilhamento das plantas, mas sim, propiciar condições de melhor utilização da forragem produzida.

Tabela 8. Taxas de aparecimento de perfilhos (perfilhos.100 perfilhos $^{-1} \cdot$ dia $^{-1}$ ) durante as épocas do ano.

\begin{tabular}{|c|c|c|c|c|}
\hline \multicolumn{4}{|c|}{ Interceptação de Luz (\%) } & \multirow[b]{2}{*}{ Média da Época } \\
\hline Resíduo $(\mathrm{cm})$ & 95 & 100 & Média & \\
\hline \multicolumn{5}{|c|}{ Primavera } \\
\hline 30 & $1,04^{\mathrm{Aa}}(0,093)$ & $0,73^{\mathrm{Ab}}(0,093)$ & $0,88^{\mathrm{B}}(0,066)$ & \multirow[t]{2}{*}{$0,97^{\mathrm{A}}(0,046)$} \\
\hline 50 & $1,25^{\mathrm{Aa}}(0,093)$ & $0,88^{\mathrm{Ab}}(0,093)$ & $1,07^{\mathrm{A}}(0,066)$ & \\
\hline \multirow[t]{2}{*}{ Média } & $1,14^{\mathrm{a}}(0,066)$ & $0,81^{\mathrm{b}}(0,066)$ & & \multirow{5}{*}{$1,27^{\mathrm{A}}(0,122)$} \\
\hline & & Verão & & \\
\hline 30 & $1,44^{\mathrm{Aa}}(0,245)$ & $1,33^{\mathrm{Aa}}(0,245)$ & $1,38^{\mathrm{A}}(0,173)$ & \\
\hline 50 & $1,29^{\mathrm{Aa}}(0,245)$ & $1,04^{\mathrm{Aa}}(0,245)$ & $1,16^{\mathrm{A}}(0,173)$ & \\
\hline \multirow[t]{2}{*}{ Média } & $1,36^{\mathrm{a}}(0,173)$ & $1,18^{\mathrm{a}}(0,173)$ & & \\
\hline & & Outono & & \multirow{3}{*}{$0,66^{\mathrm{B}}(0,053)$} \\
\hline 30 & $0,76^{\mathrm{Aa}}(0,106)$ & $0,63^{\mathrm{Aa}}(0,106)$ & $0,69^{\mathrm{A}}(0,751)$ & \\
\hline 50 & $0,48^{\mathrm{Bb}}(0,106)$ & $0,80^{\mathrm{Aa}}(0,106)$ & $0,64^{\mathrm{A}}(0,751)$ & \\
\hline \multirow[t]{2}{*}{ Média } & $0,62^{\mathrm{a}}(0,751)$ & $0,71^{\mathrm{a}}(0,751)$ & & \multirow{5}{*}{$0,60^{\mathrm{B}}(0,049)$} \\
\hline & & Inverno & & \\
\hline 30 & $0,57^{\mathrm{Aa}}(0,099)$ & $0,78^{\mathrm{Aa}}(0,099)$ & $0,67^{\mathrm{A}}(0,703)$ & \\
\hline 50 & $0,39^{\mathrm{Ab}}(0,099)$ & $0,66^{\mathrm{Aa}}(0,099)$ & $0,52^{\mathrm{A}}(0,703)$ & \\
\hline Média & $0,48^{\mathrm{b}}(0,703)$ & $0,72^{\mathrm{a}}(0,703)$ & & \\
\hline
\end{tabular}

Números entre parênteses correspondem ao erro padrão da média.

Médias na mesma linha seguidas da mesma letra minúscula não diferem entre si $(\mathrm{P}>0,10)$.

Médias na mesma coluna seguidas da mesma letra maiúscula não diferem entre si $(\mathrm{P}>0,10)$.

Em relação a interceptação luminosa, as taxas não diferiram no verão e no outono, tendo sido maiores para os tratamentos de 95\% IL na primavera e para os de 100\% IL no inverno, fato esse que explica a interação entre resíduo, interceptação 
luminosa e época do ano. Em situações de pastos em estádio vegetativo, a alta frequência de pastejo resulta num ambiente luminoso de melhor qualidade, favorecendo o perfilhamento. No presente experimento essa condição esteve associada ao regime de pastejos iniciados com 95\% IL. Já em situações de pastos em estádio reprodutivo, condição observada durante o outono e o inverno neste experimento e especialmente nos tratamentos de $100 \%$ IL, o florescimento permite maior disponibilidade de luz na base dos pastos, favorecendo o perfilhamento. Barbosa et al. (1997, 1998a), trabalhando com capim-Mombaça, obtiveram aumento no número de perfilhos novos mas redução no número de perfilhos remanescentes com o aumento do intervalo entre cortes $(28,35,42$ e 49 dias). Esse comportamento estaria associado à maior decapitação de perfilhos, dada a elevação do meristema apical quando aumenta-se o período de crescimento da planta, o que estimula o perfilhamento.

As taxas de aparecimento de perfilhos foram maiores no verão e na primavera quando comparadas àquelas do outono e do inverno, o que reflete, provavelmente, a abundância dos fatores de crescimento (água, luz e temperatura) típica daqueles meses do ano (Figuras 1, 2 e 3). Os dados estão de acordo com Carvalho (2000), que obteve as maiores taxas de aparecimento de perfilhos no verão para plantas do gênero Cynodon. Segundo Langer (1963), a taxa de aparecimento de perfilhos diminui ou é nula durante o período de alongamento das hastes reprodutivas, o que ocorre nos meses de outono e inverno para o capim-Mombaça nas condições de Brasil Central (Jank, 1995; Nabinger \& Medeiros, 1995).

\subsubsection{Taxas de mortalidade da população e das gerações de perfilhos}

Houve interação entre resíduo, interceptação luminosa e época do ano $(\mathrm{P}=$ 0,0138) para as taxas de mortalidade de perfilhos da população como um todo, sendo essas maiores no verão para todos os tratamentos, seguidas por aquelas referentes à primavera. No inverno foram observadas as menores taxas de mortalidade (Tabela 9). Os dados são coerentes com os resultados de Carvalho (2000) que, trabalhando com plantas do gênero Cynodon, revelou a ocorrência de altas taxas mortalidade associadas a 
altas taxas de aparecimento de perfilhos durante a mesma época do ano. A ocorrência sincronizada de altas taxas de aparecimento e morte de perfilhos caracterizou um padrão intenso de renovação (turnover) da população durante a primavera $(71 \%)$ e verão $(85 \%)$.

Tabela 9. Taxas de mortalidade de perfilhos (perfilhos.100 perfilhos $^{-1}$. dia $^{-1}$ ) durante as épocas do ano.

\begin{tabular}{|c|c|c|c|c|}
\hline \multicolumn{4}{|c|}{ Interceptação de Luz (\%) } & \multirow[b]{2}{*}{ Média da Época } \\
\hline Resíduo (cm) & 95 & 100 & Média & \\
\hline \multicolumn{5}{|c|}{ Primavera } \\
\hline 30 & $0,89^{\mathrm{Aa}}(0,058)$ & $0,71^{\mathrm{Ab}}(0,058)$ & $0,80^{\mathrm{A}}(0,041)$ & $0,77^{\mathrm{B}}(0,029)$ \\
\hline 50 & $0,68^{\mathrm{Ba}}(0,058)$ & $0,81^{\mathrm{Aa}}(0,058)$ & $0,74^{\mathrm{A}}(0,041)$ & \\
\hline Média & $0,78^{\mathrm{a}}(0,041)$ & $0,76^{\mathrm{a}}(0,041)$ & & \\
\hline \multicolumn{5}{|c|}{ Verão } \\
\hline 30 & $1,04^{\mathrm{Aa}}(0,095)$ & $0,99^{\mathrm{Aa}}(0,095)$ & $1,02^{\mathrm{A}}(0,067)$ & $0,95^{\mathrm{A}}(0,047)$ \\
\hline 50 & $0,89^{\mathrm{Aa}}(0,095)$ & $0,86^{\mathrm{Aa}}(0,095)$ & $0,88^{\mathrm{A}}(0,067)$ & \\
\hline Média & $0,97^{\mathrm{a}}(0,067)$ & $0,93^{\mathrm{a}}(0,067)$ & & \\
\hline \multicolumn{5}{|c|}{ Outono } \\
\hline 30 & $0,62^{\mathrm{Aa}}(0,048)$ & $0,60^{\mathrm{Aa}}(0,048)$ & $0,61^{\mathrm{A}}(0,034)$ & \multirow[t]{2}{*}{$0,56^{\mathrm{C}}(0,024)$} \\
\hline 50 & $0,52^{\text {Aa }}(0,048)$ & $0,52^{\mathrm{Aa}}(0,048)$ & $0,52^{\mathrm{A}}(0,034)$ & \\
\hline \multirow[t]{2}{*}{ Média } & $0,57^{\mathrm{a}}(0,034)$ & $0,56^{\mathrm{a}}(0,034)$ & & \multirow{5}{*}{$0,41^{\mathrm{D}}(0,022)$} \\
\hline & & Inverno & & \\
\hline 30 & $0,40^{\mathrm{Aa}}(0,045)$ & $0,46^{\mathrm{Aa}}(0,045)$ & $0,43^{\mathrm{A}}(0,031)$ & \\
\hline 50 & $0,38^{\mathrm{Aa}}(0,045)$ & $0,41^{\mathrm{Aa}}(0,045)$ & $0,39^{\mathrm{A}}(0,031)$ & \\
\hline Média & $0,39^{\mathrm{a}}(0,031)$ & $0,43^{\mathrm{a}}(0,031)$ & & \\
\hline
\end{tabular}

Números entre parênteses correspondem ao erro padrão da média.

Médias na mesma linha seguidas da mesma letra minúscula não diferem entre si $(\mathrm{P}>0,10)$.

Médias na mesma coluna seguidas da mesma letra maiúscula não diferem entre si $(\mathrm{P}>0,10)$.

De uma forma geral, não houve diferença entre os tratamentos $(P=0,4500)$ para as taxas de mortalidade da população de perfilhos, exceção feita à primavera, quando a mortalidade foi maior para o tratamento 30/95 em relação aos demais, corroborando os resultados de Korte et al (1984), Matthew (1992), Hernandez Garay (1997), Carvalho et 
al. (1999) e Carvalho (2000), que observaram aumento na mortalidade de perfilhos para os tratamentos correspondentes a desfolhas mais severas e frequentes.

A análise dos padrões de mortalidade de perfilhos por geração foi realizada conforme sugerido por Matthew et al. (1999) e apresentada por Carvalho (2000) para plantas do gênero Cynodon. As contagens dos números de perfilhos de cada geração, em cada data de avaliação, foram passadas para escala logarítmica, de forma que uma regressão simples entre esses valores e o número de dias de realização do experimento (0 a 411) resultou em equações lineares do tipo $\mathrm{a}+\mathrm{bx}$ altamente significativas $(\mathrm{P}=0,01$ a 0,0001$)$ e com valores de coeficiente de determinação elevados $\left(R^{2}=0,73\right.$ a 1,0$)$.

A inclinação dessa retas, dada pelos seus coeficientes angulares, reflete o padrão de mortalidade das gerações de perfilhos. Retas paralelas ou de coeficientes angulares semelhantes indicam um padrão homogêneo e uniforme de mortalidade. Dessa forma, procedeu-se uma análise de variância dos coeficientes angulares das retas pertencentes a cada uma das gerações estudadas. Os resultados revelaram o efeito de geração (época da marcação) $(\mathrm{P}=0,0001)$, de interceptação luminosa $(\mathrm{P}=0,0470)$ e de intensidade de pastejo $(\mathrm{P}=0,0574)$. Foi observado um maior coeficiente angular (maior mortalidade) para os tratamentos mais intensos (resíduo de $30 \mathrm{~cm}$ ) quando comparados aos menos intensos (resíduo de $50 \mathrm{~cm}$ ) (Tabela 10), corroborando os dados obtidos por Carvalho et al. (1999) em estudo com os capins Aruana (Panicum maximum cv. Aruana), Mombaça e Tanzânia, e por Carvalho (2000) com plantas do gênero Cynodon. 
Tabela 10. Coeficientes angulares das gerações de perfilhos estudadas para os resíduos de 30 e $50 \mathrm{~cm}$.

\begin{tabular}{cccc}
\hline \multirow{3}{*}{ Geração } & 30 & Resíduo & Média \\
\hline 1 & $-0,01268$ & $-0,01146$ & $-0,01207^{\mathrm{A}}(0,000463)$ \\
2 & $-0,01023$ & $-0,00788$ & $-0,00905^{\mathrm{B}}(0,000463)$ \\
3 & $-0,00894$ & $-0,00827$ & $-0,00860^{\mathrm{B}}(0,000463)$ \\
4 & $-0,01027$ & $-0,00840$ & $-0,00933^{\mathrm{B}}(0,000474)$ \\
5 & $-0,00932$ & $-0,00892$ & $-0,00912^{\mathrm{B}}(0,000463)$ \\
Média & $-0,01029^{\mathrm{a}}(0,000423)$ & $-0,00899^{\mathrm{b}}(0,000421)$ & \\
\hline
\end{tabular}

Números entre parênteses correspondem ao erro padrão da média.

Médias na mesma linha seguidas da mesma letra minúscula não diferem entre si $(\mathrm{P}>0,10)$.

Médias na mesma coluna seguidas da mesma letra maiúscula não diferem entre si $(\mathrm{P}>0,10)$.

$1^{\mathrm{a}}$ geração = gerações dos meses de janeiro e fevereiro; $2^{\mathrm{a}}$ geração = gerações dos meses de março e abril; $3^{\mathrm{a}}$ geração $=$ gerações dos meses de maio a agosto; $4^{\mathrm{a}}$ geração $=$ gerações dos meses de setembro e outubro; $5^{\text {a }}$ geração $=$ gerações dos meses de novembro e dezembro.

Foram observados, também, maiores valores de coeficiente angular para os tratamentos mais frequentes (Tabela 11), indicando que a associação de alta frequência e alta intensidade de desfolha condicionou a ocorrência de altas taxas de mortalidade. Segundo Marshall (1987) e Matthew et al. (1999), altas taxas de mortalidade necessitam ser compensadas por altas taxas de aparecimento para que o pasto não entre em colapso e inicie um processo de degradação. De forma contrária, Barbosa et al. (1997, 1998a) obtiveram menor número de perfilhos remanescentes a medida que se aumentou o intervalo entre cortes (28, 35, 42 e 49 dias) do capim-Mombaça. Essa maior mortalidade foi justificada pelo alongamento das hastes quando diminuiu-se a frequência de cortes, que deixou o meristema apical numa posição mais susceptível à remoção pelo corte ou pastejo. Costa et al. (1997) trabalharam com capim-Tobiatã e determinaram que não houve remoção de meristemas apicais quando o corte foi efetuado aos 28 dias; dos 42 aos 56 dias a eliminação foi relativamente baixa, enquanto que a partir dos 70 dias houve uma porcentagem elevada de decapitação de perfilhos. 
Tabela 11. Coeficientes angulares das gerações de perfilhos estudadas para os pastejos realizados com 95 e $100 \%$ IL.

\begin{tabular}{cccc}
\hline & \multicolumn{3}{c}{ Interceptação } \\
Geração & 95 & 100 & Média \\
\hline 1 & $-0,01198$ & $-0,01217$ & $-0,01207^{\mathrm{A}}(0,000463)$ \\
2 & $-0,00888$ & $-0,00923$ & $-0,00905^{\mathrm{B}}(0,000463)$ \\
3 & $-0,00785$ & $-0,00936$ & $-0,00860^{\mathrm{B}}(0,000463)$ \\
4 & $-0,00845$ & $-0,01022$ & $-0,00933^{\mathrm{B}}(0,000474)$ \\
5 & $-0,00759$ & $-0,01064$ & $-0,00912^{\mathrm{B}}(0,000463)$ \\
Média & $-0,00895^{\mathrm{a}}(0,01032)$ & $-0,000421^{\mathrm{b}}(0,000423)$ & \\
\hline
\end{tabular}

Números entre parênteses correspondem ao erro padrão da média.

Médias na mesma linha seguidas da mesma letra minúscula não diferem entre si $(\mathrm{P}>0,10)$.

Médias na mesma coluna seguidas da mesma letra maiúscula não diferem entre si $(\mathrm{P}>0,10)$.

$1^{\mathrm{a}}$ geração $=$ gerações dos meses de janeiro e fevereiro; $2^{\mathrm{a}}$ geração $=$ gerações dos meses de março e abril; $3^{\mathrm{a}}$ geração $=$ gerações dos meses de maio a agosto; $4^{\mathrm{a}}$ geração $=$ gerações dos meses de setembro e outubro; $5^{\text {a }}$ geração $=$ gerações dos meses de novembro e dezembro.

A maior mortalidade (maior coeficiente angular) de perfilhos observada para a primeira geração em relação às demais pode ser atribuída às roçadas de uniformização que ocorreram no início do experimento, particularmente nos piquetes correspondentes aos tratamentos de resíduo $30 \mathrm{~cm}$. Exceção feita a essa época, não houve diferenças durante as demais épocas do ano, revelando um padrão bastante uniforme de mortalidade ao longo do ano e a não existência de uma geração específica de perfilhos que mereceria maior atenção para fins de manejo, conforme proposto por Santos (1997). Santos (2002), em estudo com capim-Tanzânia, não encontrou geração alguma que se destacasse em termos de participação na produção total de forragem.

Os maiores coeficientes angulares para os tratamentos de resíduo $30 \mathrm{~cm} \mathrm{e} \mathrm{de}$ pastejo iniciado a 95\% IL indicam gerações de menor longevidade, que propiciam um perfil mais jovem da população de perfilhos nas condições desses tratamentos e sua combinação (tratamento 30/95) (Figuras 14, 15, 16 e 17). Essa característica da população de perfilhos pode influenciar a produção de forragem do pasto, uma vez que perfilhos mais jovens apresentam taxas de crescimento mais altas que perfilhos mais velhos (Carvalho et al., 2001). 
Foram analisados, também, os valores de intercepto das retas. O valor de intercepto seria um indicador do número inicial de perfilhos para uma dada geração. Constatou-se uma interação entre interceptação luminosa e geração de perfilhos $(\mathrm{P}=$ 0,0015). O efeito de interceptação luminosa revelou que os tratamentos menos frequentes (100\% IL) apresentaram os maiores valores de intercepto (maior população inicial de perfilhos) quando comparados aos de 95\% IL nas gerações 3, 4 e 5 (Tabela 12). Esse fato revela que o maior alongamento de hastes nesses tratamentos deve ter resultado em ambiente luminoso de melhor qualidade em pós-pastejo, estimulando o perfilhamento que gerou um maior número inicial de perfilhos das gerações citadas. Além disso, a eliminação de perfilhos velhos incentiva o perfilhamento pela redução do efeito de dominância apical (Salisbury \& Ross, 1992).

Tabela 12. Intercepto das gerações de perfilhos estudadas para os pastejos realizados com 95 e $100 \%$ IL.

Interceptação de Luz

\begin{tabular}{cccc} 
Geração & 95 & 100 & Média \\
\hline 1 & $4,52^{\mathrm{Ca}}(0,127)$ & $4,64^{\mathrm{Da}}(0,127)$ & $4,58^{\mathrm{D}}(0,090)$ \\
2 & $4,94^{\mathrm{Ba}}(0,113)$ & $4,91^{\mathrm{Ca}}(0,113)$ & $4,92^{\mathrm{C}}(0,081)$ \\
3 & $5,88^{\mathrm{Ab}}(0,169)$ & $6,83^{\mathrm{Ba}}(0,169)$ & $6,35^{\mathrm{B}}(0,119)$ \\
4 & $5,82^{\mathrm{Ab}}(0,212)$ & $6,47^{\mathrm{Ba}}(0,229)$ & $6,14^{\mathrm{B}}(0,156)$ \\
5 & $6,40^{\mathrm{Ab}}(0,340)$ & $7,95^{\mathrm{Aa}}(0,340)$ & $7,17^{\mathrm{A}}(0,240)$ \\
Média & $5,51^{\mathrm{b}}(0,104)$ & $6,16^{\mathrm{a}}(0,106)$ &
\end{tabular}

Números entre parênteses correspondem ao erro padrão da média.

Médias na mesma linha seguidas da mesma letra minúscula não diferem entre si $(\mathrm{P}>0,10)$.

Médias na mesma coluna seguidas da mesma letra maiúscula não diferem entre si $(\mathrm{P}>0,10)$.

$1^{\mathrm{a}}$ geração = gerações dos meses de janeiro e fevereiro; $2^{\mathrm{a}}$ geração = gerações dos meses de março e abril; $3^{\mathrm{a}}$ geração $=$ gerações dos meses de maio a agosto; $4^{\mathrm{a}}$ geração $=$ gerações dos meses de setembro e outubro; $5^{\text {a }}$ geração $=$ gerações dos meses de novembro e dezembro.

Houve efeito de geração de perfilhos $(P=0,0001)$, sendo o maior valor de intercepto observado para a geração 5, seguida das gerações 3 e 4, e o menor valor para a geração 1. Nas estações de outono e inverno verificou-se o desenvolvimento reprodutivo dos pastos, bem como as menores taxas de aparecimento, que acabaram 
refletindo numa população de perfilhos mais velhos e com maior alongamento de hastes. Dentro desse perfil de população de perfilhos seria de se esperar que com o início da estação de crescimento (primavera) ocorressem taxas mais altas de aparecimento (Tabela 8). A geração 5 está incluída nesse contexto, pois corresponde a média das gerações nos meses de novembro e dezembro, o que justifica o maior valor de intercepto observado para essa geração.

O menor valor de intercepto ocorreu para a geração 1 (correspondente as gerações dos meses de janeiro e fevereiro) refletindo, mais uma vez, o padrão intenso de renovação da população de perfilhos no verão que, apesar de um número inicial menor de perfilhos, esteve associado a um grande número de gerações de perfilhos, dado pela ocorrência de um maior número de pastejos nessa época.

\subsubsection{Taxas de sobrevivência}

Houve efeito de época do ano $(\mathrm{P}=0,0001)$, de interceptação de luz $(\mathrm{P}=0,0001)$ e de resíduo $(\mathrm{P}=0,0338)$ para as taxas de sobrevivência (Tabelas 13 e 14), com os maiores valores observados durante o verão e a primavera, de forma coincidente com as maiores taxas de aparecimento e de mortalidade durante a época de crescimento vegetativo das plantas. Certamente a maior sobrevivência nessa época do ano se deveu às plantas encontrarem-se em pleno estádio vegetativo, com perfilhos em início de desenvolvimento e pontos de crescimento mais baixos, desfrutando de ambiente com disponibilidade de luz, temperatura, água e nutrientes. Com relação à interceptação de luz, as maiores taxas de sobrevivência foram observadas para os tratamentos mais frequentes (95\% IL) comparativamente aos menos frequentes (100\% IL) durante o verão e a primavera apenas. Provavelmente a explicação se deva ao fato de que os perfilhos produzidos sob o regime de desfolha mais frequente eram menores e, por isso, menos vulneráveis a desfolha relativamente àqueles produzidos nos tratamentos de pastejo iniciado a 100\% IL (maior período de descanso). Plantas após os 95\% IL tendem a iniciar processo intenso de competição por luz, com os perfilhos dos tratamentos de 
100\% IL alongando mais hastes e elevando o meristema apical como forma de permanecerem vivos e produtivos sob aquelas circunstâncias.

Tabela 13. Taxas de sobrevivência de perfilhos (perfilhos.100 perfilhos ${ }^{-1} \cdot \operatorname{dia}^{-1}$ ) para os pastejos iniciados com 95\% IL e 100\% IL durante as estações do ano.

\begin{tabular}{cccc}
\hline \multicolumn{4}{c}{ Interceptação de Luz } \\
Época & 95 & 100 & Média \\
\hline Primavera & $2,76^{\mathrm{Aa}}(0,134)$ & $1,33^{\mathrm{Ab}}(0,134)$ & $2,05^{\mathrm{A}}(0,094)$ \\
Verão & $2,56^{\mathrm{Aa}}(0,134)$ & $1,52^{\mathrm{Ab}}(0,134)$ & $2,04^{\mathrm{A}}(0,094)$ \\
Outono & $0,89^{\mathrm{Ba}}(0,134)$ & $0,59^{\mathrm{Ba}}(0,134)$ & $0,74^{\mathrm{B}}(0,094)$ \\
Inverno & $1,05^{\mathrm{Ba}}(0,134)$ & $0,78^{\mathrm{Ba}}(0,134)$ & $0,91^{\mathrm{B}}(0,094)$ \\
Média & $1,82^{\mathrm{a}}(0,067)$ & $1,05^{\mathrm{b}}(0,067)$ & \\
\hline
\end{tabular}

Números entre parênteses correspondem ao erro padrão da média.

Médias na mesma linha seguidas da mesma letra minúscula não diferem entre si $(\mathrm{P}>0,10)$.

Médias na mesma coluna seguidas da mesma letra maiúscula não diferem entre si $(\mathrm{P}>0,10)$.

Tabela 14. Taxas de sobrevivência de perfilhos (perfilhos.100 perfilhos ${ }^{-1} \cdot$ dia $^{-1}$ ) para os resíduos de 30 e $50 \mathrm{~cm}$ durante as estações do ano.

\begin{tabular}{cccc}
\hline & \multicolumn{2}{c}{ Resíduo } & Média \\
\hline Época & 30 & 50 & $2,05^{\mathrm{A}}(0,094)$ \\
Primavera & $1,80^{\mathrm{Ab}}(0,134)$ & $2,29^{\mathrm{Aa}}(0,134)$ & $2,04^{\mathrm{A}}(0,094)$ \\
Verão & $1,85^{\mathrm{Ab}}(0,134)$ & $2,23^{\mathrm{Aa}}(0,134)$ & $0,74^{\mathrm{B}}(0,094)$ \\
Outono & $0,70^{\mathrm{Ca}}(0,134)$ & $0,78^{\mathrm{Ba}}(0,134)$ & $0,91^{\mathrm{B}}(0,094)$ \\
Inverno & $1,05^{\mathrm{Ba}}(0,134)$ & $0,78^{\mathrm{Ba}}(0,134)$ & \\
Média & $1,35^{\mathrm{a}}(0,067)$ & $1,52^{\mathrm{a}}(0,067)$ & \\
\hline
\end{tabular}

Números entre parênteses correspondem ao erro padrão da média.

Médias na mesma linha seguidas da mesma letra minúscula não diferem entre si $(\mathrm{P}>0,10)$.

Médias na mesma coluna seguidas da mesma letra maiúscula não diferem entre si $(\mathrm{P}>0,10)$.

Os tratamentos de resíduo $30 \mathrm{~cm}$ apresentaram menores taxas de sobrevivência que os de resíduo $50 \mathrm{~cm}$ no mesmo período, corroborando os resultados de Santos (2002), que observou maior renovação da população de perfilhos de capim-Tanzânia em pastos submetidos a alta intensidade de pastejo, onde os perfilhos com mais de 100 dias representavam apenas $17 \%$ do total relativamente aos tratamentos de intensidade média 
e baixa (20 e 34\%, respectivamente). Coelho et al. (1999) também observaram maior sobrevivência de perfilhos em estudo com quatro cultivares de Panicum (Colonião, Mombaça, Tanzânia e Tobiatã) quando submetidos a cortes mais altos (20 vs $40 \mathrm{~cm}$ ). Em estudo com capim-Mombaça submetido a três níveis de oferta de forragem (4, 8 e 12 $\mathrm{kg}$ de MS.100 kg-1 de PV), Coelho et al. (2000) observaram menor sobrevivência de perfilhos em apenas um dos pastejos para o menor nível de oferta, não havendo diferenças entre as intensidade de desfolha nos demais pastejos.

\subsubsection{Proporção de perfilhos aéreos}

A proporção de perfilhos aéreos na população de perfilhos variou de 3,0 a 7,9\% (Tabela 15), indicando que essa categoria de perfilhos não contribuiu efetivamente para a produção de forragem do pasto. Os resultados desse experimento corroboram aqueles de Barbosa et al. (1998b), que observaram que a principal forma de perfilhamento do capim-Mombaça foi através da emissão de perfilhos basais.

Tabela 15. Porcentagem de perfilhos aéreos nos pastos durante as estações do ano.

\begin{tabular}{cc}
\hline Época & Perfilhos aéreos $(\%)$ \\
\hline Primavera & $6,0^{\mathrm{B}}(0,89)$ \\
Verão & $3,0^{\mathrm{C}}(0,43)$ \\
Outono & $5,6^{\mathrm{B}}(0,80)$ \\
Inverno & $7,9^{\mathrm{A}}(1,35)$ \\
\hline
\end{tabular}

Números entre parênteses correspondem ao erro padrão da média.

Médias na mesma coluna seguidas da mesma letra não diferem entre si $(\mathrm{P}>0,10)$.

Não houve efeito de resíduo $(\mathrm{P}=0,9925)$ e de interceptação luminosa $(\mathrm{P}=$ 0,5260), tendo sido observado apenas efeito de época do ano $(\mathrm{P}=0,0001)$. A maior porcentagem de perfilhos aéreos foi encontrada no inverno, como resultado da maior ocorrência de perfilhos florescidos e que têm a tendência de emitir perfilhos aéreos de suas gemas axilares (observação visual). Não houve diferença entre outono e primavera, épocas que apresentaram as maiores incidências de perfilhos aéreos em relação ao verão, 
consequência, ainda, do período de desenvolvimento reprodutivo iniciado no outono (ocorrência de perfilhos florescidos vivos ainda no início da primavera). Barbosa et al. (1996) encontraram predominância de perfilhos aéreos na rebrotação durante o inverno e

a primavera para os capins Colonião, Tanzânia e Tobiatã. Apesar de mais numerosos, esses eram menos vigorosos, contribuindo menos do que os perfilhos basais para a massa de forragem do pasto. O resultado foi atribuído ao comportamento estacional dos cultivares quanto ao crescimento reprodutivo, que resultou na elevação do meristema apical facilitando a sua eliminação, fato esse que levaria a uma ativação preferencial de gemas axilares em detrimento às gemas basais.

\subsection{Densidade populacional de perfilhos}

\subsubsection{Pré-pastejo}

A densidade populacional de perfilhos em pré-pastejo não foi diferente para os tratamentos estudados, tendo sido observado apenas o efeito de época do ano $(\mathrm{P}=$ 0,0005), situação em que os maiores valores ocorreram durante o verão e o outono, e os menores na primavera (Tabela 16).

Tabela 16. Densidade populacional de perfilhos em pré-pastejo no verão, outono e primavera.

\begin{tabular}{cl}
\hline Época* $^{*}$ & Perfilhos.m $^{-2}$ \\
\hline Primavera & $344^{\mathrm{B}}(15,4)$ \\
Verão & $400^{\mathrm{A}}(11,3)$ \\
Outono & $384^{\mathrm{A}}(28,5)$ \\
\hline
\end{tabular}

Médias na mesma coluna seguidas da mesma letra não diferem entre si ( $\mathrm{P}>0,10)$.

*Valores para o inverno não foram calculados em função do número muito pequeno de pastejos realizados nessa época do ano.

As maiores taxas de aparecimento foram observadas durante o verão e a primavera. No entanto, a densidade populacional foi menor durante a primavera, o que pode ser consequência do florescimento das plantas observado durante o outono e o 
inverno. Hernandez Garay et al. (1997) apontaram as taxas altas de aparecimento de perfilhos na primavera como principais responsáveis pela alta densidade populacional de perfilhos do verão, e as maiores reduções em densidade populacional como consequência do desenvolvimento reprodutivo das plantas de azevém perene. De fato, as menores taxas de aparecimento foram observadas no período de outono e inverno, o que foi associado a menores taxas de sobrevivência e também de mortalidade.

Embora as taxas de aparecimento na primavera tenham sido altas, não devem ter sido suficientemente grandes para compensar a baixa densidade populacional herdada do período de inverno, consequência do desenvolvimento reprodutivo das plantas. Considerando que a disponibilidade de luz é um dos fatores de maior interferência na taxa de aparecimento de perfilhos, é esperado que as flutuações estacionais na disponibilidade de energia luminosa levem a mudanças na densidade populacional de perfilhos de uma pastagem (Matthew et al, 1999). Foi observada uma baixa insolação durante o mês de dezembro como consequência da grande quantidade de chuvas que ocorreram nesse período (Figura 2), fato que pode ter prejudicado o aparecimento de perfilhos na primavera.

O verão revelou intensa renovação de perfilhos (altas taxas de aparecimento e de mortalidade) que, em última análise, gerou a maior densidade populacional observada, dados que corroboram aqueles obtidos por Carvalho (2000) em estudo com plantas do gênero Cynodon spp. Para os capins Tanzânia e Mombaça, a densidade populacional foi maior no final da primavera (novembro/dezembro) (Santos, 1997; Santos, 2002) e menor na fase de desenvolvimento reprodutivo (Santos, 1997), mantendo-se relativamente constante no resto do ano.

Segundo Korte (1986), Matthew (1992), Hernandez Garay (1997) e Matthew et al. (1999), comunidades de plantas em pastagens procuram ajustar-se às diferentes condições e intensidades de desfolha, e a otimização do IAF de um pasto em situações de alta intensidade de desfolha é alcançada através de uma maior densidade populacional de perfilhos pequenos. No presente estudo o tratamento de pastejo mais intenso $(30 \mathrm{~cm})$ não obteve maior densidade populacional de perfilhos, o que está relacionado ao fato desse tratamento não ter apresentado taxas de aparecimento maiores 
que o tratamento menos intenso $(50 \mathrm{~cm}$ ) (Tabela 8). Esse resultado corrobora os dados de Santos (2002), que não obteve diferenças entre intensidades de pastejo em estudo com capim-Tanzânia e justificou o resultado pela elevada fertilidade do solo, que estaria estimulando o aparecimento de novos perfilhos nas áreas onde a mortalidade foi mais elevada. Além disso, a amplitude de intensidades de pastejo testadas não teria sido grande o suficiente para promover diferenças. Herling et al. (1999), trabalhando com capim-Mombaça submetido a intensidades de pastejo caracterizadas por ofertas de forragem de 3,3; 4,1 e 4,9\% do peso vivo animal e período de descanso de 28 e 35 dias, também não verificaram variações em densidade populacional de perfilhos.

Segundo Korte (1986), uma maior densidade populacional de perfilhos é esperada em pastos sujeitos a desfolhas mais frequentes por diminuir o efeito de sombreamento, inerente de comunidades de plantas no final do período de rebrotamento, e reduzir o risco de ocorrência de morte dependente de densidade populacional de perfilhos. Grant \& King (1983) mencionaram a ocorrência de um "lag" de tempo entre o estabelecimento de competição por luz num dossel e o início do processo de morte de perfilhos correspondente. O intervalo médio entre pastejos de 36 dias observado no período de crescimento vegetativo para os tratamentos de 100\% IL (Tabela 3) não foi, portanto, longo o suficiente para promover a morte de perfilhos (auto-desbaste). Costa et al. (1997), estudando o capim-Colonião (Panicum maximum Jacq.) e o capim-Tobiatã, não obtiveram diferenças em densidade populacional de perfilhos considerando-se cortes realizados a cada 28 e 35 dias. Porém, o aumento no intervalo de descanso para 42 dias determinou queda no número de perfilhos. $\mathrm{m}^{-2}$. Em experimento realizado por Herling et al. (1998a) com os capins Tanzânia e Mombaça, a densidade populacional de perfilhos foi influenciada apenas pelo nível de resíduo no pós-pastejo e pela época do ano, não havendo efeito significativo do período de descanso (35 e 42 dias). Braga (2001) também não observou efeito do intervalo entre cortes (28 e 42 dias) na densidade populacional de perfilhos do capim-Mombaça. 


\subsubsection{Pós-pastejo}

Em condições de pós-pastejo ocorreu efeito de interceptação de luz $(\mathrm{P}=0,0964)$ e de época do ano $(\mathrm{P}=0,0504)$ sobre a densidade populacional de perfilhos (Tabela 17).

Tabela 17. Densidade populacional de perfilhos em pós-pastejo para os pastejos iniciados com 95 e 100\% IL na primavera, verão e outono.

\begin{tabular}{cccc}
\hline & \multicolumn{3}{c}{ Interceptação de Luz } \\
Época * & 95 & 100 & Média \\
\hline Primavera & 332 & 294 & $313^{\mathrm{B}}(14,9)$ \\
Verão & 375 & 332 & $354^{\mathrm{A}}(14,9)$ \\
Outono & 355 & 303 & $329^{\mathrm{AB}}(14,9)$ \\
Média & $354^{\mathrm{a}}(16,8)$ & $310^{\mathrm{b}}(16,8)$ & \\
\hline
\end{tabular}

Médias na mesma linha seguidas da mesma letra minúscula não diferem entre si $(\mathrm{P}>0,10)$. Médias na mesma coluna seguidas da mesma letra maiúscula não diferem entre si $(\mathrm{P}>0,10)$.

*Valores para o inverno não foram calculados em função do número muito pequeno de pastejos ocorridos durante essa época do ano.

Em termos de época do ano, a densidade populacional de perfilhos no póspastejo seguiu a mesma tendência descrita para o pré-pastejo, com os maiores valores encontrados para a época de verão e os menores para a primavera, com o outono apresentando um valor intermediário.

A menor densidade populacional de perfilhos em pós-pastejo para os tratamentos com início de pastejo com 100\% IL pode ser justificada pelo maior tamanho e altura dos perfilhos resultante desse tratamento, favorecendo a perda de forragem e o pisoteio, que levou a redução do número de perfilhos no pós em relação ao pré-pastejo (observação visual). Como esses tratamentos mantiveram uma alta taxa de aparecimento (exceto na primavera) e as taxas de mortalidade não diferiram relativamente aos tratamentos de pastejo mais frequentes, esses conseguiram assegurar uma densidade populacional no pré-pastejo semelhante aos demais tratamentos. 


\subsection{Acúmulo de forragem}

\subsubsection{Taxas de acúmulo}

Houve interação entre resíduo, interceptação luminosa e época do ano $(\mathrm{P}=$ 0,0019) para as taxas de acúmulo. As maiores taxas de acúmulo ocorreram para os tratamentos de $95 \%$ IL no meses de janeiro, fevereiro e outubro em relação aos de $100 \%$ IL, que apresentaram as maiores taxas em março, setembro, novembro e dezembro (Tabela 18). Santos (1997) observou taxas de acúmulo líquido decrescentes de 28 para 48 dias de intervalo entre pastejos no período de novembro a abril, sendo essa redução mais expressiva entre 28 e 38 dias, e no período de maio a setembro as taxas de acúmulo tenderam a aumentar com o intervalo entre pastejos, resultado, provavelmente, do desenvolvimento reprodutivo das plantas naquelas condições.

Para o resíduo de $30 \mathrm{~cm}$, as taxas foram maiores em março, setembro, outubro e janeiro de 2002 e menores no mês de abril, relativamente ao resíduo $50 \mathrm{~cm}$ (Tabela 18). Machado et al. (1997) não encontraram influência da altura de corte (20 e $40 \mathrm{~cm}$ ) na produção de massa seca de oito genótipos de Panicum maximum Jacq.

Tabela 18. Taxas de acúmulo (kg MS.ha $\left.{ }^{-1} \cdot \mathrm{dia}^{-1}\right)$ para os tratamentos ao longo do período experimental.

\begin{tabular}{|c|c|c|c|c|}
\hline \multirow{2}{*}{$\begin{array}{l}\text { Resíduo } \\
\text { (cm) }\end{array}$} & \multicolumn{2}{|c|}{ Interceptação de Luz (\%) } & \multirow[b]{2}{*}{ Média } & \multirow[b]{2}{*}{ Média do Mês } \\
\hline & 95 & 100 & & \\
\hline 30 & $99,4^{\mathrm{Aa}}(16,23)$ & $\begin{array}{c}\text { Janeiro/01 } \\
88,8^{\mathrm{Aa}}(18,27)\end{array}$ & $94,1^{\mathrm{A}}(12,22)$ & $117,8^{\mathrm{B}}(8,38)$ \\
\hline 50 & $206,0^{\mathrm{Aa}}(16,23)$ & $77,2^{\mathrm{Ab}}(16,23)$ & $141,6^{\mathrm{A}}(11,48)$ & \\
\hline Média & $152,7^{\mathrm{a}}(11,48)$ & $83,0^{\mathrm{b}}(12,22)$ & & \\
\hline 30 & $94,5^{\mathrm{Aa}}(16,23)$ & $\begin{array}{c}\text { Fevereiro/01 } \\
87,6^{\text {Aa }}(16,23)\end{array}$ & $91,0^{\mathrm{A}}(11,48)$ & $105,2^{\mathrm{C}}(8,11)$ \\
\hline 50 & $174,0^{\mathrm{Aa}}(16,23)$ & $64,8^{\mathrm{Ab}}(16,23)$ & $119,4^{\mathrm{A}}(11,48)$ & \\
\hline Média & $134,2^{\mathrm{a}}(11,48)$ & $\begin{array}{c}76,2^{\mathrm{b}}(11,48) \\
\text { Março/01 }\end{array}$ & & \\
\hline 30 & $111,7^{\mathrm{Aa}}(16,23)$ & $109,2^{\mathrm{Ab}}(16,23)$ & $110,4^{\mathrm{A}}(11,48)$ & $91,5^{\mathrm{E}}(8,11)$ \\
\hline 50 & $70,3^{\mathrm{Bb}}(16,23)$ & $75,0^{\mathrm{Ba}}(16,23)$ & $72,7^{\mathrm{B}}(11,48)$ & \\
\hline Média & $91,0^{\mathrm{b}}(11,48)$ & $92,1^{\mathrm{a}}(11,48)$ & & \\
\hline
\end{tabular}


(cont.)

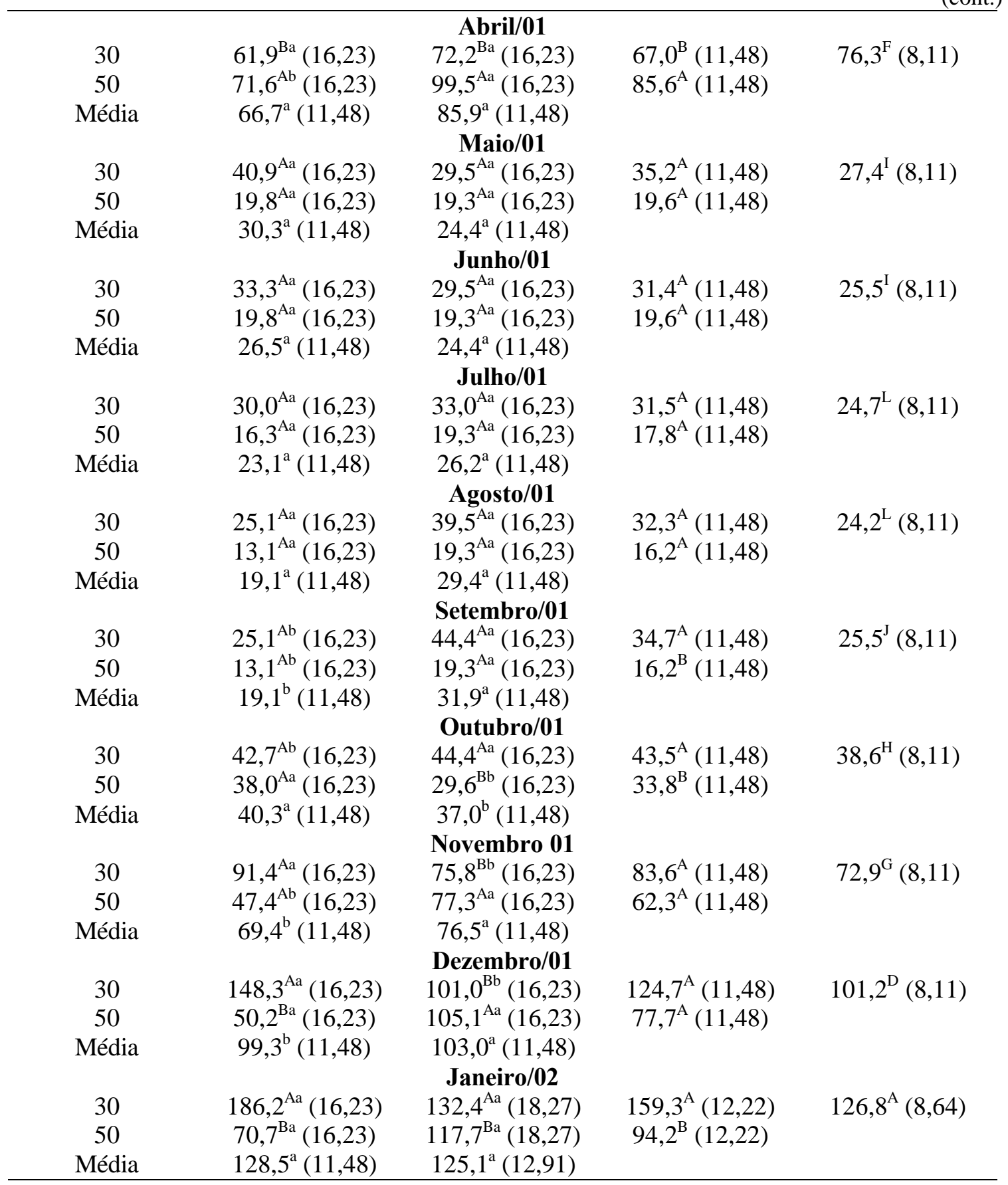

Números entre parênteses correspondem ao erro padrão da média.

Médias na mesma linha seguidas da mesma letra minúscula não diferem entre si $(\mathrm{P}>0,10)$.

Médias na mesma coluna seguidas da mesma letra maiúscula não diferem entre si $(\mathrm{P}>0,10)$. 
A estacionalidade de produção foi clara, com as maiores taxas de acúmulo ocorrendo nos meses de maior disponibilidade de fatores de crescimento (dezembro a março). Como não houve efeito dos tratamentos na densidade populacional de perfilhos (Tabelas 16 e 17), as taxas de acúmulo de forragem devem ter refletido variações nas taxas de expansão de folhas e alongamento de hastes de perfilhos individuais. Reduções observadas a partir do mês de abril refletiram o início do estádio reprodutivo, já que o desenvolvimento da inflorescência nos perfilhos leva ao cessamento da emissão de novas folhas podendo inibir, ainda, o aparecimento de novos perfilhos, o que levaria a uma subsequente redução da produção do pasto (Cooper, 1983).

\subsubsection{Acúmulo total de forragem}

Foi identificado efeito de época do ano $(\mathrm{P}=0,0001)$, caracterizando a acentuada estacionalidade de produção de forragem típica do capim-Mombaça. O acúmulo de massa seca por época do ano (Tabela 19) reflete as taxas de acúmulo apresentadas na Tabela 18, sendo que cerca de $44 \%$ da produção total anual foi concentrada no verão, $29 \%$ na primavera, $17 \%$ no outono e $10 \%$ no inverno. Cecato et al. (1996) obtiveram $81 \%$ da produção do capim-Mombaça no período de crescimento vegetativo.

Tabela 19. Acúmulo total de massa seca $\left(\mathrm{kg}_{\mathrm{h}} \mathrm{ha}^{-1}\right)$ para os resíduos de 30 e $50 \mathrm{~cm}$ nas épocas do ano.

\begin{tabular}{ccccc}
\hline \multicolumn{2}{c}{ Resíduo } & Média & $\%$ \\
\hline Época & $7.920^{\mathrm{Ba}}(661,3)$ & $5.330^{\mathrm{Bb}}(661,3)$ & $6.620^{\mathrm{B}}(467,6)$ & 29,2 \\
Primavera & $11.070^{\mathrm{Aa}}(661,3)$ & $8.680^{\mathrm{Ab}}(661,3)$ & $9.880^{\mathrm{A}}(467,6)$ & 43,6 \\
Verão & $4.050^{\mathrm{Ca}}(661,3)$ & $3.760^{\mathrm{Ca}}(661,3)$ & $3.900^{\mathrm{C}}(467,6)$ & 17,2 \\
Outono & $3.020^{\mathrm{Ca}}(661,3)$ & $1.540^{\mathrm{Da}}(661,3)$ & $2.280^{\mathrm{D}}(467,6)$ & 10,0 \\
Inverno & $6.510^{\mathrm{a}}(330,6)$ & $4.830^{\mathrm{b}}(330,6)$ & & \\
Média &
\end{tabular}

Números entre parênteses correspondem ao erro padrão da média.

Médias na mesma linha seguidas da mesma letra minúscula não diferem entre si $(\mathrm{P}>0,10)$.

Médias na mesma coluna seguidas da mesma letra maiúscula não diferem entre si $(\mathrm{P}>0,10)$. 
Não houve efeito de interceptação luminosa (condição para o início do pastejo) $(P=0,9614)$, resultado semelhante ao de Braga (2001), que também não observou diferenças em produção de forragem do capim-Mombaça para os intervalos entre cortes de 28 e 42 dias. O mesmo comportamento foi obtido por Correa et al. (1998), em estudo com 12 gramíneas forrageiras tropicais, que observou redução da produção de massa seca por corte com a diminuição da idade das plantas. Porém, quando considerou-se a produção total de massa seca do período experimental, as diferenças não foram acentuadas ou não existiram, pois as menores produções por corte foram compensadas pelo maior número de colheitas nos cortes mais frequentes. Já Herling et al.(1998b) obtiveram maior produção de massa seca verde com intervalo entre desfolhas de 35 dias em relação ao de 42 dias, e maior quantidade de forragem (massa seca total) para o intervalo entre desfolhas de 42 dias, em estudo com capim-Mombaça, indicando que o diferencial positivo em favor do intervalo de 42 dias foi devido ao acúmulo de material morto. A porcentagem média de folhas e hastes no material vivo foi $60 \%$ e $40 \%$, respectivamente, não havendo diferença entre os intervalos de desfolha estudados.

Carvalho et al. (2000), trabalhando com cinco gramíneas forrageiras tropicais, encontraram taxas de acúmulo de forragem semelhantes para os intervalos entre cortes de 30 e 45 dias, mas o maior teor de fibra insolúvel em detergente neutro (FDN) foi determinado para cortes aos 42 por Oliveira et al. (2001). Costa et al. (1997) estudaram a produção de massa seca do capim-Tobiatã submetido a seis idades de corte $(28,42,56$, 70, 84, 98 dias) e observaram aumento da produção com a idade das plantas. Revelaram, também, redução drástica nos teores de proteína bruta $(\mathrm{PB})$ e na digestibilidade in vitro da forragem a partir dessa idade, revelando que o aumento em produção além dos 42 dias de crescimento era consequência, principalmente, do acúmulo de hastes e material morto. Esses resultados apontam para o risco potencial de colheita atrasada sobre o valor nutritivo da forragem, indicando que os benefícios da maior produção de massa seca podem ser negados em função do maior acúmulo de material morto e hastes, menor valor nutritivo da forragem e maior ocorrência de perdas do pastejo.

Quanto à produção total de forragem durante o período experimental, houve efeito apenas de resíduo $(\mathrm{P}=0,0057)$. Os dados apresentados na Tabela 20 revelam 
claramente o maior diferencial de produção gerado pela variação em resíduo pós-pastejo relativamente à variação em condição para início dos pastejos (95 e 100\% IL).

Tabela 20. Produção total de massa seca $\left(\mathrm{kg} \cdot \mathrm{ha} \mathrm{a}^{-1}\right)$.

\begin{tabular}{cccc}
\hline $\begin{array}{c}\text { Interceptação } \\
\text { de Luz (\%) }\end{array}$ & 30 & 50 & Médíduo (cm) \\
\hline 95 & 27.220 & 18.230 & 22.720 \\
100 & 24.870 & 20.390 & 22.630 \\
Média & $26.050^{\mathrm{a}}(3.990)$ & $19.300^{\mathrm{b}}(3.990)$ & 22.675 \\
\hline
\end{tabular}

Médias na mesma linha seguidas da mesma letra não diferem entre si $(\mathrm{P}>0,10)$.

A produção de forragem de um pasto é resultado da produção por perfilho e do número de perfilhos por unidade de área (densidade populacional). Não foram observadas diferenças entre os tratamentos quanto à densidade populacional, o que implica que as diferenças em produção de forragem devem ter sido consequência de diferenças em produção por perfilho. Carvalho et al. (2001) em estudo com os cultivares Mombaça e Tanzânia, analisou as taxas de alongamento foliar em perfilhos de 3 categorias: velhos (com mais de 4 meses de vida), maduros (entre 2 e 4 meses de vida) e novos (entre 1 e 2 meses de vida). Observou que os perfilhos maduros apresentavam taxas de alongamento foliar duas vezes superiores àquelas de perfilhos velhos e mais altas que perfilhos novos, concluindo que folhas de perfilhos velhos contribuem progressivamente menos para a produção de forragem.

A análise das Figuras 14, 15, 16 e 17 e Tabelas 8, 9, 10, 11, 13 e 14 revela que os tratamentos de resíduo $30 \mathrm{~cm}$ e condição para início do pastejo de $95 \%$ IL apresentaram a maior renovação de perfilhos, implicando em um perfil mais jovem dos perfilhos da população. No entanto, segundo uma ordem decrescente de produção, os tratamentos foram agrupados na sequência 30/95, 30/100, 50/100 e 50/95. Apesar da população mais jovem de perfilhos, os tratamentos de $95 \% \mathrm{IL}$, especialmente o 50/95, apresentaram as menores produções, indicando que provavelmente o benefício da maior renovação de perfilhos foi compensado pela maior longevidade dos mesmos (menor mortalidade Figuras 14 e 15) e menor utilização da forragem produzida, uma vez que uma maior 
proporção da massa de forragem existente teve que deixar de ser colhida a fim de que o resíduo de $50 \mathrm{~cm}$ pudesse ser mantido. Esse fato não ocorreu para os tratamentos de resíduo $30 \mathrm{~cm}$, razão pela qual o tratamento 30/95, cujo perfil da população de perfilhos era mais jovem que o tratamento 30/100, produziu a maior quantidade de forragem. No presente experimento, o resíduo de $30 \mathrm{~cm}$ não foi planejado para ser drástico o suficiente para reduzir a produção do pasto, mas sim para promover uma colheita mais eficiente da forragem produzida.

Esses resultados revelam claramente a maior importância da intensidade relativamente ao intervalo entre pastejos, certamente consequência de sua influência sobre a eficiência de utilização da forragem produzida. O intervalo entre pastejos seria um otimizador da resposta à intensidade de desfolha, controlando a estrutura do dossel (relação vivo:morto e folha:haste) e o valor nutritivo da forragem produzida. Exemplo disso foi a dificuldade de manutenção do resíduo de $30 \mathrm{~cm}$ no tratamento 30/100, neste experimento.

Santos (2002), trabalhando com capim-Tanzânia, observou maior renovação da população de perfilhos nos tratamentos submetidos a alta intensidade de desfolha, sendo que os perfilhos com mais de 100 dias de vida representavam cerca de $13 \%$ apenas da massa de forragem total, enquanto que nos tratamentos de baixa intensidade de desfolha esse número subia para cerca de 33\%. Korte et al.(1984), trabalhando com azevém perene, observaram que os perfilhos novos contribuíam mais para a produção de forragem no pastejo mais intenso do que no pastejo mais leniente. Entretanto, Gomes (2001), em estudo com capim-Mombaça, obteve maior produção de forragem com a menor intensidade de desfolha estudada (oferta de $12 \%$ do peso animal), resultado, contudo, do aumento do acúmulo de hastes em relação a lâminas foliares.

De uma forma geral, a evidência existente é que pastos de Panicum acumulam massa seca total de forma contínua. No entanto, a partir de determinada fase de rebrotação essa produção se dá como consequência do acúmulo de material morto e hastes, componentes indesejáveis do ponto de vista de alimentação animal e eficiência do pastejo. Os dados do presente experimento permitem inferir que o início do pastejo 
com 95\% IL seria indicado e que o resíduo de $30 \mathrm{~cm}$ permitiria a melhor utilização da forragem produzida. 


\section{CONCLUSÕES}

A altura do pasto é um parâmetro confiável para ser utilizado como guia de manejo baseado em condição de interceptação luminosa para início do pastejo.

A maior produção de forragem foi obtida com pastejos iniciados a 95\% IL e realizados até um resíduo de $30 \mathrm{~cm}$, indicando que o pastejo deve ser iniciado quando os pastos atingem $90 \mathrm{~cm}$ de altura e interrompido quando rebaixado a $30 \mathrm{~cm}$.

Uma grande renovação de perfilhos ocorre no pasto particularmente durante a primavera e o verão, evento esse importante para assegurar a perenidade e a produtividade da pastagem, que não pode ser negligenciado no planejamento de estratégias de desfolha e colheita da forragem.

A intensidade de pastejo possui uma importância relativa maior quando comparada à frequência de desfolha, sendo esta, no entanto, chave para o controle da estrutura do pasto, particularmente do acúmulo indesejável de material morto e hastes. 


\section{REFERÊNCIAS BIBLIOGRÁFICAS}

ANDRADE, J.B. Estudo comparativo de 3 capins da espécie Panicum maximum Jacq. (colonião, tobiatã e K-187-B). Piracicaba, 1987. 133p. Dissertação (Mestrado) -

Escola Superior de Agricultura "Luiz de Queiroz", Universidade de São Paulo.

ANSLOW, R.C. The rate of appearance of leaves on tillers of gramineae. Herbage Abstracts, v. 36, p. 149-155, 1966.

BARBOSA, M.A.A.F.; DAMASCENO, J.C.; CECATO, U.; SAKAGUTI, E.S. Estudo de perfilhamento em 4 cultivares de Panicum maximum Jacq. submetidos à duas alturas de corte. In: REUNIÃO ANUAL DA SOCIEDADE BRASILEIRA DE ZOOTECNIA, 33., Fortaleza, 1996. Anais. Fortaleza:SBZ, 1996. p.106-109.

BARBOSA, M.A.A.F.; CECATO, U.; ONORATO, W.M.; COELHO, E.M. Estudo do perfilhamento do capim-Mombaça (Panicum maximum Jacq.) (compact disc). In: REUNIÃO ANUAL DA SOCIEDADE BRASILEIRA DE ZOOTECNIA, 34., Juiz de Fora, 1997. Anais. Juiz de Fora:SBZ, 1997.

BARBOSA, M.A.A.F.; CECATO, U.; ONORATO, W.M.; BERALDO, J.A.; YANAKA, F. Y.; BERTOLASSI, J.R.; PETERNELLI, M. Efeito do N e do intervalo entre corte no número de perfilhos do capim-Mombaça (Panicum maximum Jacq. cv. Mombaça). In: REUNIÃO ANUAL DA SOCIEDADE BRASILEIRA DE ZOOTECNIA, 35., Botucatu, 1998. Anais. Botucatu:SBZ, 1998a. p.99-101.

BARBOSA, M.A.A.F.; CECATO, U.; BERALDO, J.A.; YANAKA, F. Y.; ONORATO, W.M.; PETERNELli, M.; BERTOLASSI, J.R. Capim Mombaça (Panicum maximum Jacq. cv. Mombaça) (compact disc). In: REUNIÃO ANUAL DA SOCIEDADE BRASILEIRA DE ZOOTECNIA, 35., Botucatu, 1998. Anais. Botucatu:SBZ, 1998 b. 
BIRCHAM, J.S.; HODGSON, J. The influence sward conditions on rates of herbage growth and senescence in mixed swards under continuous stocking management. Grass and Forage Science, v.39, p.323-331, 1983.

BLACK, C. K.; CHU, A. C. P. Searching for an alternative way to manage prairie grass. IN: NEW ZEALAND GRASSLAND ASSOCIATION. Proceedings. v 50, p. 219-223, 1989.

BLASER, R. E.; HAMMES Jr., FONTENOT, J. P. Forage animal management systems. Blacksburg: Virginia Agricultural Experimental Station, 1986. 90 p. (Bulletin, 86-87).

BRADSHAW, A. D. Evolutionary significance of phenotypic plasticity in plants. Advances in genetics, v.13, p.115-155, 1965.

BRAGA, G. J. Resposta do capim Mombaça (Panicum maximum Jacq.) a diferentes doses de nitrogênio e intervalos de corte. Pirassununga, 2001. 122p. Dissertação (Mestrado) - Faculdade de Zootecnia e Engenharia de Alimentos, Universidade de São Paulo.

BRISKE, D.D. Strategies of plant survival in grazed systems: a functional interpretation.

In: HODGSON, J.; ILLIUS, W. (Ed.) The ecology and management of grazing systems. London: CAB International, 1996. cap.2, p.37-67.

BROUGHAM, R,W. A study in rate of pasture growth Australian Journal of Agricultural Research, v. 6, p. 804-812, 1955.

BROUGHAM, R.M. Effects of intensity of defoliation on regrowth of pastures.

Australian Journal of Agricultural Research, v.7, p.377-387, 1956.

BROUGHAM, R.M. Interception of light by the foliage of pure and mixed stands of pasture plants. Australian Journal of Agricultural Research, v.9, p.39-52, 1957.

BROUGHAM, R.W. The effects of frequency and intensity of grazing on the productivity of productivity of a pasture of short-rotation ryegrass and red and white clover. New Zealand Journal of Agricultural Resarch, v. 2, p.1232-1248,1959.

BROUGHAM, R.W. The effects of frequent hard grazings at different times of the year on the productivity and species yields of a grass-clover pastures. New Zealand Journal of Agricultural Research, v. 3, p.125-136, 1960. 
BUXTON, D.R.; FALES, S.L. Plant environment and quality. In: FAHEY Jr., G.C. (Ed.) Forage quality, evaluation, and utilization. Madison: ASA, CSSA, SSSA, 1994. cap. 4, p.155-199.

CARNEVALLI, R.A.; Da SILVA, S.C. Validação de técnicas experimentais para avaliação de características agronômicas e ecológicas de pastagens de Cynodon dactylon cv. 'Coast-Cross-1'. Scientia Agricola, v.56, p.489-499, 1999.

CARVAlHO, D.D; MATTHEW, C.; BARIONI, L.G. Participação da matéria seca e perfilhamento em três cultivares de P. maximum (Jacq.) submetidos a dois níveis de desfolhação (compact disc). In: REUNIÃO ANUAL DA SOCIEDADE BRASILEIRA DE ZOOTECNIA, 36., Porto Alegre, 1999. Anais. Porto Alegre:SBZ, 1999.

CARVALHO, C.A.B. Padrões demográficos de perfilhamento e acúmulo de forragem em pastagens de Cynodon spp. manejadas em quatro intensidades de pastejo. Piracicaba, 2000. 96p. Dissertação (Mestrado)- Escola Superior de Agricultura Luiz de Queiroz, Universidade de São Paulo.

CARVALHO, M.V.B.; SILVA, L.C.; DUBEUX Jr., J.C.B; SANTOS, M.V.F.; FERREIRA, R.L.C. Efeito da idade de corte sobre a produtividade de gramíneas tropicais. In: CONGRESSO NORDESTINO DE PRODUÇÃO ANIMAL, 2. Anais. Teresina, 2000. p.78-80.

CARVALHO, D.D; MATTHEW, C.; J. HODGSON, Effect of aging in tillers of Panicum maximum on leaf elongation rate. In: INTERNATIONAL GRASSLAND CONGRESS, 19., São Pedro, 2001. Proceedings. São Pedro: FEALQ, 2001. p.41-42.

CECATO, U.; MARCO, A.A.F.B.; SAKAGUTI, E.S.; DAMASCENO, J.C.; SUZUKI,

E.; MEURER, F. Avaliação de cultivares de Panicum maximum Jacq. In: REUNIÃO ANUAL DA SOCIEDADE BRASILEIRA DE ZOOTECNIA, 34., Fortaleza, 1996. Anais. Fortaleza:SBZ, 1996. p. 403-406.

CHAPMAN, D.F.; LEMAIRE, G. Morphogenetic and strutural deterninants of plant regrowth after defoliation. In: BACKER M. J. (Ed). Grassland of our world. Wellington: SIR, 1993. cap.3, p.55-64. 
CORREA, L.A.; FREITAS, A.R.; BATISTA, L.A.R. Níveis de nitrogênio e frequências de corte em 12 gramíneas forrageiras tropicais. I - produção de matéria seca (compact disc). In: REUNIÃO ANUAL DA SOCIEDADE BRASILEIRA DE ZOOTECNIA, 35., Botucatu, 1998. Anais. Botucatu:SBZ, 1998.

COELHO, E.M.; CECATO, U.; BARBOSA, M.A.A.F.; YANAKA, F. Y. Características do perfilhamento em quatro cultivares de Panicum maximum Jacq. (compact disc). In: REUNIÃO ANUAL DA SOCIEDADE BRASILEIRA DE ZOOTECNIA, 36., Porto Alegre, 1999. Anais. Porto Alegra:SBZ, 1999.

COELHO, E.M.; GOMES, M.A.; HERLING, V.R.; LIMA, C.G. Sobrevivência e eliminação de meristemas apicais de perfilhos remanescentes do capim Mombaça (Panicum maximum Jacq.) sob pastejo (compact disc). In: REUNIÃO ANUAL DA SOCIEDADE BRASILEIRA DE ZOOTECNIA, 37., Viçosa, 2000. Anais. Viçosa:SBZ, 2000.

COOPER, J.P. Physiological and morphological advances for forage improvement. In: INTERNATIONAL GRASSLAND CONGRESS, 14., Lexington, 1981. Proceedings. Boulder: Westview Press, 1983. p. 125-137.

COSTA, N.L.; OLIVEIRA, J.R.C. Produção de forragem e composição química de Panicum maximum cv. Tobiatã em diferentes idades de corte (compact disc). In: REUNIÃO ANUAL DA SOCIEDADE BRASILEIRA DE ZOOTECNIA, 34., Juiz de Fora, 1997. Anais. Juiz de Fora:SBZ, 1997.

DA SILVA, S. C.; HODGSON, J.; MATTHEW, P. N. P.; MATTHEW C. Effects of contrasting spring grazing management on summer-autumn pasture and milk production of mixed ryegrass-clover dairy swards. Proceedings of the New Zealand Society of Animal Production, v. 54, p. 79-82, 1994.

DALE, J.E. Some effects of temperature and irradiance on growth of the first four leaves of wheat Triticum aestivum. Annals of Botany, v.50, p.851-858, 1982.

DAVIES, A. Leaf tissue remaining after cutting and regrowth in perennial ryegrass. Journal of Agricultural Science, v.82, p.165-172, 1974. 
DAVIES, A. Structure of the grass sward. INTERNATIONAL MEETING ON ANIMAL PRODUCTION FROM TEMPERATE GRASSLAND, Dublin, 1977. Proceedings. Dublin, 1977. p.36-44.

DAVIES, A.; EVANS, M.E.; EXLEY, J.K. Regrowth of perennial ryegrass as affected by simulated leaf sheaths. Journal of Agricultural Science, v.101, p.131-137, 1983.

DAVIES, A.; THOMAS, H. Rates of leaf and tiller production in young spaced perennial ryegrass plants in relation to soil temperature and solar radiation. Annals of Botany, v.51, p.591-597, 1983.

DAVIES, A. The regrowth of grass swards. In: JONES, M.B.; LAZENBY, A. (Ed.) The grass crop. London: Chapman and Hall, p.85-127, 1988.

DEREGIBUS, V. A., SANCHEZ, R. A., CASAL, J.J. Effects of light quality on tiller production in Lolium ssp. Plant Physiology, v. 72, p. 900-912, 1983.

DURAND, J.L.; VARLET-GRANCHER, C.; LEMAIRE, G.; GASTAL, F.; MOUILIA, B. Carbon partitioning in forage crops. Acta Biotheoretica, v.39, p.213-224, 1991.

EMBRAPA (Br). Sistema brasileiro de classificação de solos. Serviço Nacional de Levantamento e Conservação de Solos. Brasília: EMBRAPA produção de informação, 1999, 412p.

FAGUNDES, J.L. Efeito de intensidade de pastejo sobre o índice de área foliar, interceptação luminosa e acúmulo de forragem em pastagens de cynodon spp.. Piracicaba, 1999. 69 p. Dissertação (Mestrado). Escola Superior de Agricultura "Luiz de Queiroz", Universidade de São Paulo.

GASTAL, F.; BÉLANGER, G.; LEMAIRE G. A model of leaf extension rate of tall fescue in response to nitrogen and temperature. Annals of Botany, v. 70, p. 437-442, 1992.

GASTAL, F.; BÉLANGER, G. The effects of nitrogen and the growing season on photosynthesis of fieldgrown tall fescue canopies. Annals of Botany, v. 72, p. 401-408, 1993.

GILLET, M.; LEMAIRE, G.; GOSSE, G. Essai d'élaboration d’um schéma global de croissance des graminées fourragères. Agronomie, v.4, p.75-82, 1984. 
GOMES, M.A. Efeitos de intensidades de pastejo e períodos de ocupação da pastagem na massa de forragem e nas perdas e valor nutritivo da matéria seca do capim Mombaça (Panicum maximum Jacq. cv. Mombaça). Pirassununga, 2001. 93p. Dissertação (Mestrado) - Faculdade de Zootecnia e Engenharia de Alimentos, Universidade de São Paulo.

GRANT, S.A.; BARTHRAM, G.T.; TORVELL, L. Components of regrowth in grazed and cut Lolium perenne swards. Grass and Forage Science, v, 36, p. 155-168, 1981.

GRANT, S.A.; BARTHRAM, G.T.; TORVELL, L.; KING, J.; SMITH, H.K. Sward management lamina turnover and tiller population density in continuously stocked Lolium perenne - dominated swards. Grass and Forage Science, v.38, p.333-344, 1983.

HERLING, V.R.; JANTALIA, C.P.; PIAZZA, C.; SUDA, C.H.; CERQUEIRA, P.H.; LIMA, C.G. Fisiologia de perfilhamento do capim Mombaça (Panicum maximum Jacq. cv. Mombaça) sob pastejo (compact disc). In: REUNIÃO ANUAL DA SOCIEDADE BRASILEIRA DE ZOOTECNIA, 35., Botucatu, 1998. Anais. Botucatu:SBZ, 1998a.

HERLING, V.R.; JANTALIA, C.P.; PIAZZA, C.; SUDA, C.H.; CERQUEIRA, P.H.; LIMA, C.G. Determinação da matéria seca disponível do capim Mombaça (Panicum maximum Jacq. cv. Mombaça) sob pastejo (compact disc). In: REUNIÃO ANUAL DA SOCIEDADE BRASILEIRA DE ZOOTECNIA, 35., Botucatu, 1998. Anais. Botucatu:SBZ, 1998 b.

HERLING, V.R.; SISTI, C.P.J; LUZ, P.H.C; LIMA，C.G.;RODRIGUES，L.R.A.; PIAZZA, C.; RUFATTO, J.C.; LEITA, D.M.O. Eliminação de meristema apical e perfilhamento do capim Mombaça (Panicum maximum Jacq. cv. Mombaça) sob pastejo. In: SIMPÓSIO INTERNACIONAL “GRASSLAND ECOPHYSIOLOGY AND GRAZING ECOLOGY”,1., Curitiba, 1999, Anais. Curitiba:UFPR, 1999. p. 375-377. 
HERNANDEZ GARAY, A.; MATTHEW, C.; HODGSON, J. Effect of spring management on perennial ryegrass and ryegrass-white clover pastures. 2. Tiller and growing point densities and population dynamics. New Zealand Journal of Agricultural Research, v.40, p. 35-70, 1997.

HODGSON, J. ; BIRCHAM, J.S.; GRANT, S.A.; KING, J. The influence of cutting and grazing management on herbage growth and utilization. In : WRIGHT, C.E., Plant Physiology and Herbage Production. British Grassland Society, p. 51-62. 1981.

HODGSON, J. Grazing management - science into practice. Essex: Longman Scientific \& Technical, 1990. 203p.

JANK, L. Melhoramento e seleção de variedades de Panicum maximum.. Manejo da Pastagem - Tema: o capim-Colonião. Piracicaba:FEALQ, 1995. p.21-58.

JEWISS, O. R. Morphological and physiological aspects of the growth of grasses during the vegetative phase. In: THE GROWTH OF CEREAL AND GRASSES, 12., London, 1966. Proceedings of the twelfth Easter School in Agricultural Science. London: MILTHORPE F. L.; IVINS J. D. , 1966. p. 39-56, 1966.

KAYS, S.; HARPER, J.L. The regulation of plant and tiller density in a grass sward. Journal of Ecology, v.62, p.97-105, 1974.

KORTE, C.J.; WATKIN, B.R.; HARRIS,W. Use of residual leaf area index and light interception as criteria for spring-grazing management of a ryegrass-dominant pasture. New Zealand Journal of Agricultural Research, v. 25, p.309-319, 1982.

KORTE, C.J.; WATKIN, B.R.; HARRIS,W. Effects of the timing and intensity of spring grazing on reproductive development, tillering, and herbage production of perennial ryegrass dominant pasture. New Zealand Journal of Agricultural Research, v.27, p.135-149,1984.

KORTE, C.J. Tillering in 'Grasslands Nui' perennial ryegrass swards. 2. Seasonal pattern of tillering and age of flowering tillers with two mowing frequencies. New Zealand Journal of Agricultural Research, v.29, p.629-638,1986. 
LAMBERT, M.G.; CLARK, D.A.; GRANT, D.A.; COSTALL, D.A.; GRAY, Y.S. Influence of fertiliser and grazing management on North Island moist hill country 4. Pastures species abundance. New Zealand Journal of Agricultural Research, v.29, p.23-31, 1986.

LANGER, R.H.M. Growth and nutrition of timothy (Phleum pratense) 1. The life history of individual tillers. Annals of Applied Biology, v. 44. P. 166-187, 1956.

LANGER, R.H.M. Tillering in herbage grass. A review. Herbage Abstracts, v.33, p.141-148, 1963.

LANGER, R.H.M. How grasses grow. London: 2. ed., Edward Arnold, London, 1979. $66 \mathrm{p}$.

LEMAIRE, G.; CULLETON N. Effects of nitrogen applied after the last cut in autumn an a tall fescue sward. 2. Uptake and recycling of nitrogen in the sward during winter. Agronomie, v. 9, p. 241-249, 1989.

LEMAIRE, G.; CHAPMAN, D. Tissue flows in grazed plant communities. In: HODGSON, J.; ILLIUS, A.W. (Ed.) The ecology and management of grazing systems. Guildford: CAB International, 1996. cap.1, p.3-36.

LEMAIRE, G.; AGNUSDEI, M. Leaf tissue turn-over and efficiency of herbage utilization. In: SIMPÓSIO INTERNACIONAL “GRASSLAND ECOPHYSIOLOGY AND ECOLOGY”, 1., Curitiba, 1999. Anais. Curitiba: UFPR, 1999, p.165-183.

LEMAIRE, G. Ecophysiology of grasslands: Dynamics aspects of forage plant populations in grazed swards. In: INTERNATIONAL GRASSLAND CONGRESS, 19., São Pedro, 2001. Proceedings. São Pedro: FEALQ, 2001. p.29-37.

L'HUILLIER, P.J. Tiller appearance and death of Lolium perenne in mixed swards grazed by dairy cattle at two stocking rates. New Zealand Journal of Agricultural Research, v.30, p.15-22, 1987.

LONSDALE, W.M.; WATKINSON, A.R. Light and self-thinning. New Phytologist, v. 90, p.431-445, 1982. 
MACHADO, A.O.; CECATO, U.; MIRA, R.T.; PEREIRA, L.A.F.; MARTINS, E.N.; DAMASCENO, J.C.; SANTOS, G.T. Avaliação de genótipos de Panicum maximum (Jacq) em duas alturas de corte (compact disc). In: REUNIÃO ANUAL DA SOCIEDADE BRASILEIRA DE ZOOTECNIA, 34., Juiz de Fora, 1997. Anais. Juiz de Fora:SBZ, 1997.

MARSHALL, C. Physiological aspects of pasture growth. In: SNAYDON, R.W. (Ed.). Managed Grasslands. Amsterdam: Elsevier, 1987. cap. 4, p.29-46.

MATTHEW, C.; XIA J. X.; CHU, A. C. P.; MACKAY, A. D.; HODGSON, J. Relationship between root production and tiller appearence rates in perennial ryegrass (Lolium perenne L.). In: ATKINSON, D. (Ed.) Plant root growth and ecological perspective. Oxford: Blackwell Scientific Publication, 1991. (British Ecological Society, special publication n 10.) p. 281-290.

MATTHEW, C. A study of seasonal root and tiller dynamics in swards of perennial ryegrass (Lolium perenne L.). Palmerston North, 1992. (Ph-D) Thesis. Massey University.

MATTHEW, C.; BLACK, C. K.; BUTLER, B. M. Tiller dynamics of perennation in three herbage grasses. In: INTERNACIONAL GRASSLANDS CONGRESS, 17. Wellington, 1993. Proceedings. Wellington:SIR, 1993. p. 141-143.

MATTHEW, C.; LEMAIRE, G.; SACKVILLE HAMILTON, N.R.; HERNÁNDEZ GARRAY, A. A modified self-thinning equation do describe size/density relationships for defoliated swards. Annals of Botany, v.76, p.579-587, 1995.

MATTHEW, C.; ASSUERO, S.G.; BLACK, C.K.; SACKVILLE HAMILTON. Tiller dynamics of grazed swards. In: SIMPÓSIO INTERNACIONAL "GRASSLAND ECOPHYSIOLOGY AND GRAZING ECOLOGY”, Curitiba, 1999. Anais. Curitiba: UFPR/UFRGS, 1999. p.109-133.

MAZZANTI, A.; LEMAIRE, G.; GASTAL, F. The effect of nitrogen fertilisation on the herbage production of tall fescue swards grazed continuously with sheep. 1. Herbage growth dynamics. Grass and Forage Science, v.49, p.111-120, 1994. 
MITCHELL, K.J. Influence of light and temperature on the growth of ryegrass (Lolium spp.). 2. The control of lateral bud development. Physiologia Plantarum, v.6, p.425443, 1953.

NABINGER, C.; MEDEIROS, R.B.; Produção de sementes de Panicum maximum Jacq. SIMPÓSIO SOBRE MANEJO DA PASTAGEM, 12., Piracicaba, 1995. Anais. Piracicaba:FEALQ, 1995. p.21-58.

NELSON, C.J.; ZARROUGH, K.M. Tiller density and tiller weight as yield determinants of vegetative swards. In: PLANT PHYSIOLOGY AND HERBAGE PRODUCTION, BIANNUAL SYMPOSIUM, Nottingham, 1981. Proceedings. Nottingham: British Grassland Society, 1981. p.25-29.

NELSON, C.J.; MOSER, L.E. Plant factors affecting forage quality. In: FAHEY Jr.,

G.C. (Ed.) Forage quality, evaluation, and utilization. Madison: ASA, CSSA, SSSA, 1994. cap. 3, p.115-154.

NEUTEBOOM, J. H.; LANTINGA, E. A. Tillering potencial and relationship between leaf and tiller production in perennial ryegrass. Annals of Botany, v. 63, p. 265-270, 1989.

OLIVEIRA, T.N.; CARVALHO, M.V.B.A.; DA SILVA, A.L.C.; DUBEUX Jr., J.C.B.; SANTOS, M.V.F.; FERREIRA, R.L.C. Composição química de gramíneas tropicais submetidas a duas frequências de corte. In: REUNIÃO ANUAL DA SOCIEDADE BRASILEIRA DE ZOOTECNIA, 38., Piracicaba, 2001. Anais. Piracicaba:SBZ, 2001. p. 107-109.

ONG, C.K.; MARSHALL, C.; SAGAR, G.R. The physiology of tiller death in grasses. 2. Causes of tiller death in grass sward. Journal of the British Grassland Society, v.17, p.205-211, 1978.

PARSONS, A. J.; ROBSON, M. J. Seasonal changes in the physiology of S24 perennial ryegrass. 1. Response of leaf extension to temperature during the transition from vegetative to reproductive growth. Annals of Botany v, 46, p. 435-444, 1980.

PAKIDING, W.; HIRATA M. Tillering in a bahiagrass (Paspalum notatum Flügge) pasture under cattle grazing 1. Results as meaned over quadrats. Journal of the Japanese Society of Grassland Science, v. 44. P. 44-45, 1998. 
PEACOCK, J. M. Temperature and leaf growth in Lolium perenne. 1. The thermal microclimate: its measurement and relation to plant growth. Journal of Applied Ecology, v. 12, p. 115-123, 1975a.

PEACOCK, J. M. Temperature and leaf growth in Lolium perenne. 3. Factors affecting seasonal differences. Journal of Applied Ecology, v. 12, p. 685-697, 1975b.

PINTO, J. C.; GOMIDE, J. A.; MAESTRI, M. Produção de matéria seca e relação folha:caule de gramíneas forrageiras tropicais, cultivadas em vasos, com duas doses de nitrogênio. Revista da Sociedade Brasileira de Zootecnia, v. 23, p. 433-440, 1994.

PINTO, L.F.M. Dinâmica do acúmulo de matéria seca em pastagens de Cynodon spp. submetidas a pastejo. Piracicaba, 2000. 124p. Dissertação (Mestrado) - Escola Superior de agricultura "Luiz de Queiroz", Universidade de São Paulo”.

ROBSON, M.J. A comparison of British and North American verieties of tall fescue. I Leaf growth during winter and the effect on it of temperature and day lenght. Journal of Applied Ecology, v.4, p.475-484, 1967.

ROBSON, M.J.; RYLE, G.J.A.; WOLEDGE, J. The grass plant - its form and function. In: JONES, M.B.; LAZENBY, A. (Ed.) The grass crop: the physiological basis of production. London: Chapman and Hall, p.25-83, 1988.

SALISBURY, F.B.; ROSS, C.W. Plant Physiology. 4. Wadsworth, 1992. 682p.

SANTOS, P.M. Estudo de características de Panicum maximum (Jacq.) cvs. Tanzânia e Mombaça para estabelecer seu manejo. Dissertação (Mestrado). Escola Superior de Agricultura “Luiz de Queiroz”, Universidade de São Paulo, 1997, 62 p.

SANTOS, P.M. Controle do desenvolvimento das hastes no Capim Tanzânia: um desafio. Tese (Doutorado). Escola Superior de Agricultura "Luiz de Queiroz", Universidade de São Paulo, 2002, 98 p.

S.A.S. INSTITUTE. SAS User's guide: statistics. Cary, 1990. 956p. 
SBRISSIA, A.F.; DA SILVA S.C.; MATTHEW, C.; PEDREIRA, C.G.S.; CARNEVALLI, R.A.; FAGUNDES, J.L.; PINTO, L.F.M.; CORTUCCI, M. Tiller size/density compensation in grazed swards of Cynodon spp. In: INTERNACIONAL SYMPOSIUM ON GRASSLAND ECOPHYSIOLOGY AND GRAZING ECOLOGY, Curitiba, 1999. Proceedings. Curitiba: Universidade Federal do Paraná, 1999. p. 348-352.

SBRISSIA, A. F.; DA SILVA, S. C. O ecossistema de pastagens e a produção animal. A Produção Animal na Visão dos Brasileiros. Sociedade Brasileira de Zootecnia, p. 731-754, 2001.

SILSBURY, J. H. Leaf growth in pasture grasses. Tropical Grasslands, v. 4, p. 17-36, 1970.

SKINNER, R.H.; NELSON, C.J. Estimation of potencial tiller production and site usage during tall fescue canopy development. Annals of Botany, v70, p. 493-499, 1992.

STODDART, J.L.; THOMAS, H., LLOYD, E.J.; POLLOCK, C.J.; The use of temperature- profiled position transducer for the study of low temperature growth in Graminae. Planta, v. 167; p. 359-363, 1986.

VALENTINE, I.; MATTHEW, C. Plant growth, development and yield. In: WHITE, J.; HODGSON, J. (Ed). New Zealand - pasture and crop science, Oxford:Oxford University press, 1999. p.11-27.

VAN LOO, E.N. Tillering, leaf expansion and growth of plants of two cultivars of perennial ryegrass grown using hydroponics at two water potentials. Annals of Botany, v. 70, p. 511-518, 1992.

WATSON, D.J. The dependence of net assimilation on leaf area index. Annals of Botany, v.22, p.255-261, 1958.

WILSON, D.B.; McGUIRE, W.S. Effects of clipping and nitrogen on competition between three pasture species. Canadian Journal of Plant Science, v. 41, p.631-642, 1961.

XIA, J.X. The effects of defoliation on tissue turnover and pasture production in perennial ryegrass, prairie grass, and smooth bromegrass, pasture. Palmerston North, 1991. Thesis (Ph.D.) - Massey University, 173p. 
YANG, J.Z.; MATTHEW, C.; ROWLAND, R.E. Tiller axis observations for perennial ryegrass (Lolium perenne L.) and tall fescue (Festuca arundinaceae Schreb.): number of active phytomers probability of tiller appearance and number of roots per phytomer for three cutting heights. New Zealand Journal of Agricultural Research, v.41, p.11-19, 1998. 